\title{
25. MINERAL CHEMISTRY OF BASALTS FROM ŌJIN, NINTOKU, AND SUIKO SEAMOUNTS, LEG 55 DSDP
}

\author{
David A. Clague, Department of Geology, Middlebury College, Middlebury, Vt. \\ and \\ Martin R. Fisk and A. E. Bence, Department of Earth and Space Sciences, State University of New York, \\ Stony Brook, N.Y.
}

\begin{abstract}
Microprobe mineral compositions of olivine, plagioclase, clinopyroxene, chrome spinel, ilmenite, and titanomagnetite are presented for 7 samples from 4 flows of hawaiite and one flow of tholeiitic basalt from Hole 430A at Ōjin Seamount, 4 samples from 3 flows of alkalic basalt from Hole 432A at Nintoku Seamount, and 29 samples from 2 flows of alkalic basalt and 24 flows of tholeitic basalt from Holes 433A, 433B, and 433C at Suiko Seamount.

The four hawaiite flows from Hole 430A on Öjin Seamount have nearly identical mineralogy. The plagioclase phenocrysts and calculated equilibrium olivine appear to have crystallized at about $1175^{\circ} \mathrm{C}$; the groundmass plagioclase crystallized from about $1135^{\circ}$ to $1010^{\circ} \mathrm{C}$; and the $\mathrm{Fe}-\mathrm{Ti}$ oxides equilibrated at temperatures from $1000^{\circ} \mathrm{C}$ to $720^{\circ} \mathrm{C}$ under oxygen fugacities of $10^{-11}$ to $10^{-17}$. The single tholeitic flow contains glomerocrysts of plagioclase $\left(\mathrm{An}_{80}\right.$ to $\left.\mathrm{An}_{65}\right)$ and clinopyroxene $\left(\mathrm{Wo}_{43} \mathrm{En}_{46} \mathrm{Fs}_{11}\right.$ to $\left.\mathrm{Wo}_{42} \mathrm{En}_{45} \mathrm{Fs}_{13}\right)$. The plagioclase phenocrysts give calculated temperatures as high as $1400^{\circ} \mathrm{C}$, indicating that they were not equilibrated with a magma having the bulk rock composition. The plagioclase groundmass crystallized at $1120^{\circ}$ to $1070^{\circ} \mathrm{C}$, and the $\mathrm{Fe}$ - $\mathrm{Ti}$ oxides equilibrated at $1070^{\circ}$ to $930^{\circ} \mathrm{C}$ under oxygen fugacities of $10^{-10}$ to $10^{-12}$. Using mineral compositions of Hawaiian basalts as a guide, we infer that the hawaiite flows were erupted during the post-caldera alkalic eruptive stage and the tholeiite was erupted during the shield-building or caldera collapse stage.

The three alkalic basalt flows from Hole 432A on Nintoku Seamount have similar mineralogy, although Flow Units 1 and 2 contain much more abundant plagioclase phenocrysts. The groundmass plagioclase crystallized at temperatures between $1175^{\circ}$ and $1000^{\circ} \mathrm{C}$. The olivine and plagioclase phenocrysts do not appear to be in equilibrium with the enclosing magmas. The mineral compositions suggest that these samples are intermediate between alkalic basalt and hawaiite; they probably erupted during the post-caldera alkalic stage of eruption.

The two analyzed alkalic basalt flows are the two youngest flows recovered at Holes 433A, 433B, and $433 \mathrm{C}$. Flow Unit 1 contains abundant sector-zoned clinopyroxene, and Flow Unit 2 contains rare kink-banded olivine xenocrysts. The plagioclase phenocrysts yield calculated temperatures of $1440^{\circ}$ to $1250^{\circ} \mathrm{C}$, indicating that they are probably not cognate. Calculated-equilibrium olivine indicates crystallization of olivine at about $1170^{\circ} \mathrm{C}$. The $\mathrm{Fe}$-Ti oxides equilibrated at temperatures of $1140^{\circ}$ to $870^{\circ} \mathrm{C}$ under oxygen fugacities of $10^{-9}$ to $10^{-14}$. The groundmass plagioclase crystallized at temperatures of $1178^{\circ}$ to $1035^{\circ} \mathrm{C}$. The mineral compositions indicate that these alkalic basalts erupted during the post-caldera alkalic eruptive stage.

The 24 analyzed tholeiitic basalts are subdivided on the basis of phenocryst abundances into olivine tholeiites, plagioclase tholeiites, and tholeiites. The crystallization sequence appears to have been chrome spinel, olivine, plagioclase, and clinopyroxene as phenocryst phases, followed by and overlapping with groundmass crystallization of plagioclase $\left(1180^{\circ}\right.$ to $\left.920^{\circ} \mathrm{C}\right)$, clinopyroxene, and Fe-Ti oxides $\left(1140^{\circ}\right.$ to $\left.670^{\circ} \mathrm{C}\right)$. At least three flows contain pigeonite. The mineral compositions indicate that all the samples from Flow Unit 4 downward are tholeiitic basalts, although Flow Unit 64 has mineral compositions transitional to those in alkalic basalts.
\end{abstract}

\section{INTRODUCTION}

Four sites were drilled in the Emperor Seamounts during Leg 55. Site 430 on Ōjin Seamount, Site 431 on Yōmei Seamount, and Site 432 on Nintoku Seamount were single-bit holes; Site 433 on Suiko Seamount was a multiple re-entry hole. The holes on Ōjin, Nintoku, and Suiko yielded subaerial lava flows petrographically and geochemically similar to those that form the principal Hawaiian Islands (see Clague and Frey, this volume, and Kirkpatrick et al., this volume).

Hole 430A on Ōjin Seamount penetrated 59.3 meters of sediments and 58.7 meters of lava flows, including four flows of hawaiite underlain by a single flow of tholeiitic basalt. Hole 432A on Nintoku Seamount penetrated three flows of alkalic basalt, totaling 31.9 meters in thickness, below 42.1 meters of sediment consisting of fossiliferous volcanic sandstone and calcareous conglomerate containing clasts of alkalic basalt, hawaiite, mugearite, calcareous algae, shells, and bryozoans. Four holes were drilled on Suiko Seamount. Holes $433 \mathrm{~A}, 433 \mathrm{~B}$, and $433 \mathrm{C}$ recovered volcanic rocks; Hole 433 was limited to a single core taken to establish the mudline. Hole $433 \mathrm{~A}$ penetrated only the uppermost flow of alkalic basalt; Hole 433B yielded the same alkalic basalt flow recovered in Hole 433A and a second 
alkalic basalt flow (Flow Unit 2). Hole 433C yielded both alkalic Flow Units 1 and 2, separated by 3 meters of reef carbonate sand rich in volcanic material, and an additional 65 numbered flow units containing as many as 112 flows or flow lobes.

This paper reports the microprobe mineral compositions of all primary phases for many of the samples analyzed for major elements (Kirkpatrick et al., Bence et al., this volume), trace elements (Clague and Frey, this volume, and Bence et al., this volume), strontium isotopic composition (Lanphere et al., this volume), and $\mathrm{K}-\mathrm{Ar}$ radiometric ages (Dalrymple et al., this volume). The detailed petrography of the analyzed samples is presented by Kirkpatrick et al. (this volume) and summarized in Table 1. Seven samples from Site 430, 4 from Site $\mathbf{4 3 2}$, and 30 from Site 433 were analyzed for olivine, chrome spinel, plagioclase, clinopyroxene, ilemite, and magnetite. We will use the mineral compositional data to (1) characterize the phase chemistry, (2) attempt to relate the mineral compositions to the bulk rock compositions, and (3) determine the crystallization history of the basalts. Fodor et al. (1975) and Keil et al. (1972) have shown that basalts from the tholeiitic shieldbuilding stage, the post-caldera alkalic stage, and the post-erosional nephelinic stage contain compositionally distinct feldspars and pyroxenes. We will apply their discriminants to the drilled basalts to aid in identifying which eruptive stages have been sampled.

\section{ANALYTIC TECHNIQUES}

The mineral analyses reported in this paper were performed at MIT and SUNY Stony Brook. The analyses at MIT were done on a 3-scanner automated EITEC electron microprobe, and the data were reduced on line, using correction procedures of Bence and Albee (1968) as modified by Albee and Ray (1970). The electron probe was operated at $15 \mathrm{kv}$ accelerating potential and $0.030 \mu \mathrm{A}$ beam current. Ilmenite, magnetite, and chromite were analyzed against the same standards with Stillwater chromite $52 \mathrm{NL}-11$ used for $\mathrm{Cr}, \mathrm{Al}$, and $\mathrm{Mg}$, a natural manganese-rich ilmenite for $\mathrm{Ti}$ and $\mathrm{Mn}$, and a synthetic spectrographically pure magnetite for Fe. Pyroxene was analyzed using a synthetic jadeitic diopside (Di Jd 35) for $\mathrm{Si}, \mathrm{Al}, \mathrm{Na}, \mathrm{Mg}$, and $\mathrm{Ca}$, a natural cossyrite for $\mathrm{Fe}$ and $\mathrm{Ti}$, the same manganese-rich ilmenite for $\mathrm{Mn}$, and a synthetic chrome diopside (Cr CAT 54) for Cr.

At SUNY Stony Brook, olivine, feldspar, pyroxene, $\mathrm{Cr}$-spinel, and opaques were analyzed using an automated four-spectrometer ARL model EmX-Sm electron probe operating at $15 \mathrm{kv}$ accelerating potential and $0.015 \mu \mathrm{A}$ specimen current. Analyses were obtained in real time using the matrix correction procedure of Bence and Albee (1968) with a correction matrix modified from that of Albee and Ray (1970). Analyses were monitored by interfacing natural and synthetic stoichiometric phases of known chemistry.

The chromite, magnetite, and ilmenite analyses have been recalculated to divide total iron into $\mathrm{Fe}^{+3}$ and $\mathrm{Fe}^{+2}$ on the basis of stoichiometry. The Fe-Ti oxides have been recalculated so that temperature of crystallization and oxygen fugacities could be calculated for coexisting ilmenite-magnetite pairs. The magnetite-ülvospinel and the ilmenite-hematite components of the opaque minerals are calculated such that $\mathrm{Mn}^{2}+$ is combined with $\mathrm{Ti} 4+$ to form $\mathrm{Mn}_{2} \mathrm{TiO}_{4}$ in the Mt-Usp series and $\mathrm{MnTiO}_{3}$ in the Ilm-Hem series and discarded. In the Mt-Usp series, $\mathrm{Mg}^{2+}$ in excess of $1 / 2\left(\mathrm{Al}^{3+}+\mathrm{Cr}^{3+}\right)$ is also combined with $\mathrm{Ti}^{4+}$ and discarded.

Chrome spinel compositions are denoted by chemical formulas, where any Ti present is calculated as $\mathrm{TiFe}_{2}^{+2} \mathrm{O}_{4}$ and the remaining iron is split to balance $\mathrm{R}_{2}{ }^{+3} \mathrm{R}^{+2} \mathrm{O}_{4}$. The clinopyroxene formulas have been calculated using the computer program of Papike et al. (1974). The mineral formulas listed in the text and in the summary tables (Tables 6, 7, and 11) and plotted in the figures (1a, $2 \mathrm{a}, 3 \mathrm{a}, 5 \mathrm{a}, 6 \mathrm{a}, 7 \mathrm{a}$, and 11a) have recombined the $\mathrm{Fe}^{2+}$ and $\mathrm{Fe}^{3+}$ calculated for the analyses as total $\mathrm{Fe}$; this is called Fs. The tables of pyroxene analyses and mineral formulas have listed both $\mathrm{Fe}^{2+}$ and $\mathrm{Fe}^{3+}$; the quadrilateral components have been calculated with all iron as $\mathrm{Fe}^{2+}$ and called Fs. We have not used the calculated $\mathrm{Fe}^{3+}$, although it is a useful calculation, so that the analyses presented here may be directly compared with other published pyroxene compositional data.

\section{RESULTS: ŌJIN SEAMOUNT, SITE 430}

Representative analyses of plagioclase, olivine, ilmenite, magnetite, and clinopyroxene are presented in Tables 2 through 5, respectively. The compositional data and calculated equilibration temperatures are summarized in Table 6.

\section{Sample 430A-4-2, 110-118 cm: Hawaiite}

This sample, from near the top of Flow Unit 1, has a trachytic texture consisting of feldspar $\left(\mathrm{An}_{54} \mathrm{Or}_{2}-\mathrm{An}_{6}\right.$ $\mathrm{Or}_{26}$ ) laths containing from 0.5 to 0.9 weight per cent " $\mathrm{FeO}$ " (Table 2), in a groundmass of granular clinopyroxene and equant $\mathrm{Fe}-\mathrm{Ti}$ oxides. The clinopyroxenes are too small to analyze, and no fresh olivine is present in our sample. The Fe-Ti oxides consist of exsolved equant titanomagnetite $\left(\mathrm{Mt}_{37}-\mathrm{Mt}_{30}\right)$ and elongate ilmenite $\left(\mathrm{Il}_{78}-\mathrm{Il}_{92}\right)$. Most analyses yield (Table 4) compositions intermediate between titanomagnetite and ilmenite, the result of beam overlap. Pyrite is common and chalcopyrite is present; both are generally located in pools of clays in the groundmass.

\section{Sample 430A-5-1, 21-27 cm: Hawaiite}

This sample from the interior of Flow Unit 1 has a trachytic texture consisting of andesine $\left(\mathrm{An}_{48} \mathrm{Or}_{3}\right)$ to potassic oligoclase $\left(\mathrm{An}_{11} \mathrm{Or}_{27}\right)$ laths containing from 0.4 to 1.2 weight per cent " $\mathrm{FeO}$ " (but averaging about 0.7 wt. \% " $\mathrm{FeO}$ "). Clinopyroxene is generally intergranular to sub-ophitic $\left(\mathrm{Wo}_{43} \mathrm{En}_{40} \mathrm{Fs}_{17}\right.$ to $\mathrm{Wo}_{42} \mathrm{En}_{37} \mathrm{Fs}_{21}$; $\mathrm{Al}_{2} \mathrm{O}_{3}=1.5$ to 2.6 wt. $\%$; $\mathrm{TiO}_{2}=1.4$ to 2.2 wt. $\%$ ). Both $\mathrm{TiO}_{2}$ and $\mathrm{Al}_{2} \mathrm{O}_{3}$ decrease and $\mathrm{MnO}$ increases with increasing iron, and $\mathrm{Cr}_{2} \mathrm{O}_{3}$ is below detectability limits $\mathrm{C}_{\mathrm{DL}} \cong 0.02$ wt. $\% \mathrm{Cr}_{2} \mathrm{O}_{3} ; \mathrm{Na}_{2} \mathrm{O}$ ranges from 0.4 to 0.6 per cent, but shows no correlation with iron. "Other" components account for 6 to 13 per cent; classification as CAMGTAL or NATAL is according to the scheme of Papike et al. (1974). No fresh olivine is present. The 
TABLE 1

Petrographic Summary of Analyzed Samples

\begin{tabular}{|c|c|c|c|c|c|c|c|c|}
\hline \multirow{2}{*}{$\begin{array}{l}\text { Sample } \\
\text { (Interval in } \mathrm{cm} \text { ) }\end{array}$} & \multirow{2}{*}{$\begin{array}{l}\text { Flow } \\
\text { Unit }\end{array}$} & \multirow[b]{2}{*}{ Rock Type } & \multicolumn{3}{|c|}{ Phenocrysts (\%) } & \multirow{2}{*}{$\begin{array}{l}\text { Dominant } \\
\text { Texture }\end{array}$} & \multirow[b]{2}{*}{ Mg Value } & \multirow[b]{2}{*}{ Alteration (all glass is replaced by smectite) } \\
\hline & & & Ol & $\mathrm{Cpx}$ & Plag & & & \\
\hline $430 \mathrm{~A}-4-2,110-118$ & 1 & Hawaiite & 0 & 0 & 0 & Subtrachytic & 34.0 & $\begin{array}{l}\text { Olivine replaced by iddingsite and smectite, some magnetite re- } \\
\text { placed by hematite. }\end{array}$ \\
\hline $430 \mathrm{~A}-5-1,21-27$ & 1 & Hawaiite & 0 & 0 & 0 & $\begin{array}{l}\text { Subtrachytic to } \\
\text { intersertal }\end{array}$ & 36.0 & Olivine replaced by smectite and rare calcite. \\
\hline $430 A-5-2,102-115$ & 1 & Hawaiite & 0 & 0 & $<1$ & $\begin{array}{l}\text { Subtrachytic, } \\
\text { vesicular }\end{array}$ & 46.1 & Most olivine replaced by iddingsite and smectite. \\
\hline $430 \mathrm{~A}-6-1,17-25$ & 2 & Hawaiite & 0 & 0 & 0 & Subtrachytic & 42.5 & Most olivine replaced by iddingsite and smectite. \\
\hline $430 A-6-3,52-63$ & 3 & Hawaiite & 0 & 0 & 0 & Subtrachytic & 41.9 & Olivine replaced by smectite. \\
\hline $430 \mathrm{~A}-6-4,7-15$ & 4 & Hawaiite & 0 & 0 & 0 & Subtrachytic & 46.1 & $\begin{array}{l}\text { Olivine replaced by smectite and iddingsite, some magnetite re- } \\
\text { placed by hematite. }\end{array}$ \\
\hline $430 \mathrm{~A}-6-4,140-150$ & 5 & $\begin{array}{l}\text { Plagioclase } \\
\text { tholeiite }\end{array}$ & 1 & 2 & 17 & Intergranular & 49.6 & Olivine replaced by iddingsite and smectite. \\
\hline $432 \mathrm{~A}-2-1,86-92$ & 1 & Alkalic basalt & 2 & 0 & 8 & Diabasic & 50.9 & $\begin{array}{l}\text { Olivine replaced by iddingsite and smectite, some magnetite re- } \\
\text { placed by hematite. }\end{array}$ \\
\hline $432 \mathrm{~A}-2-3,37-43$ & 2 & Alkalic basalt & 3 & 0 & 14 & Diabasic & 39.9 & $\begin{array}{l}\text { Olivine replaced by iddingsite, smectite, and calcite. Vesicles filled } \\
\text { with smectite. }\end{array}$ \\
\hline $432 \mathrm{~A}-3-2,120-126$ & 3 & Alkalic basalt & 1 & 0 & 0 & Intergranular & 48.2 & Olivine is about half replaced by smectite, rare phillipsite. \\
\hline $432 A-5-2,57-66$ & 3 & Alkalic basalt & 2 & 0 & 0 & Ophitic & 49.1 & Most olivine replaced by smectite. \\
\hline $433 \mathrm{~A}-20-1,30-36$ & 1 & Alkalic basalt & 0 & $1^{*}$ & 7 & Intergranular & 45.7 & Olivine replaced by smectite. \\
\hline $433 \mathrm{~A}-21-4,129-138$ & 1 & Alkalic basalt & $<1$ & 4 & 11 & Intergranular & 44.7 & $\begin{array}{l}\text { Olivine replaced by iddingsite and smectite. Vesicles filled with } \\
\text { smectite. }\end{array}$ \\
\hline $433 A-5-2,61-68$ & 1 & Alkalic basalt & $<1$ & 2 & 3 & $\begin{array}{l}\text { Intergranular to } \\
\text { subtrachytic }\end{array}$ & - & Olivine replaced by smectite. \\
\hline 433B-5-3, 85-90 & 2 & Alkalic basalt & 7 & 2 & 9 & Pilotaxitic & 51.3 & Olivine mostly replaced by smectite with iddingsite rims. \\
\hline $433 C-4-1,30-38$ & 2 & Alkalic basalt & 7 & 2 & 12 & $\begin{array}{l}\text { Pilotaxitic to } \\
\text { intergranular }\end{array}$ & 54.8 & Olivine replaced by smectite on rims and cracks. \\
\hline $433 \mathrm{C}-10-4,11-17$ & $4 \mathrm{~F}$ & $\begin{array}{l}\text { Olivine } \\
\text { tholeiite }\end{array}$ & 5 & 0 & 0 & $\begin{array}{l}\text { Variolitic, } \\
\text { vesicular }\end{array}$ & 65.9 & $\begin{array}{l}\text { Olivine replaced by clay with iddingsite rims; vesicles are clay- } \\
\text { lined. }\end{array}$ \\
\hline $433 C-12-3,57-65$ & 9 & Tholeiite & 1 & 1 & 3 & Intergranular & 59.9 & $\begin{array}{l}\text { Olivine replaced by clay and calcite with iddingsite rims; vesicles } \\
\text { are clay-and calcite-filled. }\end{array}$ \\
\hline $433 C-13-2,55-66$ & 10 & $\begin{array}{l}\text { Plagioclase } \\
\text { tholeiite }\end{array}$ & 1 & 4 & 12 & Diabasic & 57.4 & Olivine and intersertal glass replaced by clays. \\
\hline $433 \mathrm{C}-14-3,8-15$ & $11 \mathrm{~B}$ & $\begin{array}{l}\text { Plagioclase } \\
\text { tholeiite }\end{array}$ & 0 & 1 & 6 & $\begin{array}{l}\text { Intergranular, } \\
\text { vesicular }\end{array}$ & 54.0 & Vesicles are clay-lined; plagioclase cores replaced by clays. \\
\hline $433 C-15-6,16-31$ & 13 & Tholeiite & $<1$ & 1 & 1 & Intergranular & 52.4 & Olivine and groundmass glass replaced by clays. \\
\hline $433 C-19-5,57-65$ & $15 \mathrm{~A}$ & Tholeiite & 1 & $<1$ & 3 & Intergranular & 58.8 & $\begin{array}{l}\text { Olivine replaced by clays with iddingsite rims, plagioclase cores and } \\
\text { groundmass glass replaced by clays. }\end{array}$ \\
\hline $433 \mathrm{C}-21-4,7-13$ & 17 & Tholeiite & $<1$ & 0 & 1 & Intergranular & 57.1 & $\begin{array}{l}\text { Olivine replaced by iddingsite and clays; plagioclase partially, and } \\
\text { glass completely, replaced by clays and zeolites. }\end{array}$ \\
\hline $433 \mathrm{C}-22-5,45-52$ & 18 & $\begin{array}{l}\text { Plagioclase } \\
\text { tholeiite }\end{array}$ & 2 & 0 & 7 & Pilotaxitic & 54.1 & Olivine replaced by clays and iddingsite, groundmass clays after glass. \\
\hline $433 \mathrm{C}-24-7,133-139$ & 19 & $\begin{array}{l}\text { Tholeiitic } \\
\text { picrite }\end{array}$ & 39 & 0 & 0 & Diabasic & 79.1 & $\begin{array}{l}\text { Olivine partly replaced by iddingsite and clays, plagioclase partly } \\
\text { replaced by clays. }\end{array}$ \\
\hline $433 \mathrm{C}-28-2,73-80$ & 25 & $\begin{array}{l}\text { Plagioclase } \\
\text { tholeiite }\end{array}$ & 0 & 1 & 5 & Pilotaxitic & 54.5 & Olivine replaced by clays, clay patches in groundmass. \\
\hline $433 \mathrm{C}-29-1,112-123$ & $26 \mathrm{~A}$ & $\begin{array}{l}\text { Plagioclase } \\
\text { tholeiite }\end{array}$ & $<1$ & 1 & 5 & Intergranular & 54.9 & Olivine and groundmass glass replaced by clays. \\
\hline $433 \mathrm{C}-29-2,94-100$ & 26B & $\begin{array}{l}\text { Plagioclase } \\
\text { tholeiite }\end{array}$ & 1 & $<1$ & 7 & Pilotaxitic & 53.1 & $\begin{array}{l}\text { Olivine, plagioclase cores, and groundmass glass replaced by clays } \\
\text { and zeolites. }\end{array}$ \\
\hline $433 C-31-1,28-34$ & 27 & Tholeiite & 6 & 0 & 7 & Pilotaxitic & 58.1 & $\begin{array}{l}\text { Olivine altered to clay along fractures, rare plagioclase cores re- } \\
\text { placed by clays. }\end{array}$ \\
\hline $433 \mathrm{C}-34-2,103-111$ & 33 & $\begin{array}{l}\text { Olivine } \\
\text { tholeiite }\end{array}$ & 15 & 0 & 1 & Sub-ophitic & 66.2 & $\begin{array}{l}\text { Olivine replaced by clays with iddingsite rims, rare groundmass } \\
\text { patches of clays. }\end{array}$ \\
\hline $433 C-34-7,114-121$ & 35 & $\begin{array}{l}\text { Olivine } \\
\text { tholeiite }\end{array}$ & 9 & $<1$ & 3 & Pilotaxitic & 65.0 & $\begin{array}{l}\text { Olivine replaced by clays and calcite with iddingsite rims, irregular } \\
\text { clay patches in groundmass. }\end{array}$ \\
\hline $433 \mathrm{C}-37-3,79-87$ & 44 & Tholeiite & 2 & 0 & 0 & Diabasic & 61.8 & Olivine replaced by clays, some patches of groundmass clays. \\
\hline $433 C-38-1,67-76$ & $45 B$ & $\begin{array}{l}\text { Olivine } \\
\text { tholeiite }\end{array}$ & 9 & 0 & 0 & Sub-ophitic & 67.3 & $\begin{array}{l}\text { Olivine partially replaced by clays and rimmed by iddingsite, } \\
\text { abundant groundmass clays. }\end{array}$ \\
\hline $433 \mathrm{C}-39-5,87-94$ & 48 & $\begin{array}{l}\text { Olivine } \\
\text { tholeiite }\end{array}$ & 5 & 0 & 0 & Intergranular & 65.9 & Olivine mostly replaced by clays, some groundmass clays. \\
\hline $433 C-40-2,88-96$ & 49 & $\begin{array}{l}\text { Olivine } \\
\text { tholeiite }\end{array}$ & 8 & 0 & 0 & Intergranular & 67.1 & $\begin{array}{l}\text { Olivine partly replaced by clays and rimmed by iddingsite, some } \\
\text { groundmass clays. }\end{array}$ \\
\hline $433 C-42-1,56-63$ & 52 & Tholeiite & 1 & $<1$ & $<1$ & Intersertal & 57.4 & Abundant intersertal glass replaced by clays. \\
\hline $433 \mathrm{C}-42-3,11-20$ & 53 & $\begin{array}{l}\text { Plagioclase } \\
\text { tholeiite }\end{array}$ & 1 & 4 & 15 & Intersertal & 60.9 & Olivine replaced by iddingsite and glass by clays. \\
\hline $433 \mathrm{C}-42-5,85-92$ & 54 & $\begin{array}{l}\text { Plagioclase } \\
\text { tholeiite }\end{array}$ & 1 & 1 & 13 & $\begin{array}{l}\text { Diabasic, } \\
\text { intersertal }\end{array}$ & 57.8 & Olivine replaced by iddingsite and glass by clays. \\
\hline $433 \mathrm{C}-47-5,92-100$ & 64 & Tholeiite & 2 & $<1$ & 1 & Pilotaxitic & 44.6 & $\begin{array}{l}\text { Olivine replaced by iddingsite, plagioclase partially altered to clays, } \\
\text { abundant phillipsite in groundmass. }\end{array}$ \\
\hline $433 \mathrm{C}-49-2,17-24$ & 66 & Tholeiite & 1 & 1 & 2 & Diabasic & 49.1 & Olivine replaced by iddingsite and glass to clays. \\
\hline
\end{tabular}

sample contains exsolved equant titanomagnetite $\left(\mathrm{Mt}_{56}\right)$ and rare elongate ilmenite $\left(\mathrm{Il}_{86}\right)$. Most analyses yield compositions intermediate between ilmenite and titanomagnetite, indicating analysis of both phases at once.

\section{Sample 430A-5-2, 102-115 cm: Hawaiite}

This sample, from the interior of Flow Unit 1, is vesicular and has a subtrachytic texture. It contains plagioclase laths that were not analyzed, but optical techniques indicate that they are generally near $\mathrm{An}_{50}$. Microphenocrysts of clinopyroxene occur as welldeveloped grains $\left(\mathrm{Wo}_{42} \mathrm{En}_{40} \mathrm{Fs}_{18}-\mathrm{Wo}_{40} \mathrm{En}_{37} \mathrm{Fs}_{23} ; \mathrm{Al}_{2} \mathrm{O}_{3}\right.$ $=1.2$ to 3.0 wt. $\% ; \mathrm{TiO}_{2}=1.0$ to 2.2 wt. $\% ; \mathrm{MnO}=$ 0.22 to 0.36 wt. \%). Both $\mathrm{TiO}_{2}$ and $\mathrm{Al}_{2} \mathrm{O}_{3}$ increase with increasing iron and then decrease with continued increasing Fs. $\mathrm{Na}_{2} \mathrm{O}$ ranges from 0.4 to 0.5 per cent, and 
TABLE 2

Kepresentative Feldspar Analyses from Leg 55 (Oxides wt. \%)

\begin{tabular}{|c|c|c|c|c|c|c|c|c|c|c|c|c|c|c|c|c|c|}
\hline & 1 & 2 & 3 & 4 & 5 & 6 & 7 & 8 & 9 & 10 & 11 & 12 & 13 & 14 & 15 & 16 & 17 \\
\hline $\mathrm{SiO}_{2}$ & 57.5 & 64.3 & 55.0 & 50.1 & 53.7 & 64.2 & 54.4 & 54.0 & 52.9 & 49.4 & 49.0 & 48.4 & 57.2 & 51.7 & 50.9 & 48.8 & 53.1 \\
\hline $\mathrm{Al}_{2} \mathrm{O}_{3}$ & 26.6 & 21.3 & 27.9 & 31.7 & 29.4 & 21.8 & 28.5 & 28.5 & 29.2 & 31.8 & 32.5 & 32.5 & 25.7 & 29.9 & 30.3 & 31.8 & 28.0 \\
\hline $\mathrm{FeO}$ & 0.63 & 0.62 & 0.72 & 0.72 & 0.37 & 0.59 & 0.91 & 0.95 & 0.90 & 0.82 & 0.64 & 0.67 & 0.98 & 0.79 & 0.56 & 0.61 & 1.05 \\
\hline $\mathrm{MgO}$ & 0.00 & 0.00 & 0.00 & 0.07 & 0.00 & 0.00 & 0.01 & 0.01 & 0.00 & 0.10 & 0.02 & 0.02 & 0.09 & 0.12 & 0.07 & 0.05 & 0.03 \\
\hline $\mathrm{CaO}$ & 8.51 & 2.28 & 10.5 & 14.00 & 11.6 & 2.65 & 11.10 & 11.7 & 11.60 & 14.80 & 15.7 & 15.8 & 8.87 & 13.7 & 13.9 & 15.0 & 11.4 \\
\hline $\mathrm{Na}_{2} \mathrm{O}$ & 6.31 & 8.02 & 5.31 & 3.03 & 4.62 & 7.79 & 4.93 & 4.73 & 4.38 & 2.74 & 2.50 & 2.38 & 6.01 & 3.66 & 3.51 & 2.65 & 4.76 \\
\hline $\mathrm{K}_{2} \mathrm{O}$ & 0.54 & 3.23 & 0.26 & 0.07 & 0.24 & 3.12 & 0.38 & 0.29 & 0.31 & 0.10 & 0.08 & 0.08 & 0.48 & 0.11 & 0.15 & 0.15 & 0.24 \\
\hline$\Sigma$ & 100.1 & 99.7 & 99.7 & 99.7 & 99.9 & 100.2 & 100.2 & 100.2 & 99.3 & 99.8 & 100.4 & 99.9 & 99.3 & 100.0 & 99.4 & 99.1 & 98.6 \\
\hline \multicolumn{18}{|c|}{ Cations, Oxygen $=8$} \\
\hline $\mathrm{Si}$ & 2.581 & 2.873 & 2.495 & 2.291 & 2.432 & 2.855 & 2.459 & 2.448 & 2.419 & 2.264 & 2.236 & 2.222 & 2.594 & 2.358 & 2.337 & 2.257 & 2.447 \\
\hline $\mathrm{Al}$ & 1.409 & 1.122 & 1.490 & 1.710 & 1.568 & 1.145 & 1.521 & 1.522 & 1.571 & 1.722 & 1.749 & 1.760 & 1.373 & 1.607 & 1.639 & 1.730 & 1.522 \\
\hline Fe & 0.024 & 0.023 & 0.027 & 0.028 & 0.014 & $\begin{array}{l}1.145 \\
0.022\end{array}$ & 0.034 & 0.036 & 0.034 & 0.031 & 0.024 & 0.026 & 0.037 & 0.030 & $\begin{array}{l}1.039 \\
0.021\end{array}$ & 0.024 & 0.040 \\
\hline $\mathrm{Mg}$ & 0.000 & 0.000 & 0.000 & 0.005 & 0.000 & 0.000 & 0.001 & 0.001 & 0.000 & 0.007 & 0.001 & 0.001 & 0.006 & 0.008 & 0.005 & 0.003 & 0.002 \\
\hline $\mathrm{Ca}$ & 0.410 & 0.109 & 0.508 & 0.685 & 0.561 & 0.126 & 0.538 & 0.567 & 0.568 & 0.727 & 0.766 & 0.779 & 0.431 & 0.670 & 0.682 & 0.741 & 0.562 \\
\hline $\mathrm{Na}$ & 0.550 & 0.695 & 0.467 & 0.268 & 0.406 & 0.672 & 0.432 & 0.416 & 0.388 & 0.244 & 0.221 & 0.212 & 0.528 & 0.324 & 0.312 & 0.239 & 0.425 \\
\hline $\mathrm{K}$ & 0.031 & 0.184 & 0.015 & 0.004 & 0.014 & 0.177 & 0.022 & 0.017 & 0.018 & 0.006 & 0.005 & 0.005 & 0.028 & 0.006 & 0.009 & 0.009 & 0.014 \\
\hline$\Sigma$ & 5.005 & 5.006 & 5.002 & 4.991 & 4.994 & 4.997 & 5.007 & 5.007 & 4.999 & 5.000 & 5.003 & 5.006 & 4.997 & 5.004 & 5.005 & 5.001 & 5.012 \\
\hline \multicolumn{18}{|c|}{ Feldspar Components, mol \% } \\
\hline Or & 3.1 & 18.6 & 1.5 & 0.04 & 1.4 & 18.2 & 2.2 & 1.7 & 1.9 & 0.6 & 0.5 & 0.50 & 2.8 & 0.6 & 0.9 & 0.9 & 1.4 \\
\hline $\mathrm{Ab}$ & 55.5 & 70.3 & 47.2 & 28.0 & 41.4 & 68.9 & 43.6 & 41.6 & 39.84 & 25.0 & 22.3 & 21.3 & 53.5 & 32.4 & 31.1 & 24.2 & $\begin{array}{r}1.4 \\
42.5\end{array}$ \\
\hline An & 41.4 & 11.0 & 51.3 & 71.6 & 57.2 & 12.9 & 54.2 & 56.7 & 58.32 & 74.4 & 77.2 & 78.2 & 43.7 & 67.0 & 68.0 & 74.9 & 56.1 \\
\hline
\end{tabular}

TABLE 2 - Continued

\begin{tabular}{|c|c|c|c|c|c|c|c|c|c|c|}
\hline & 18 & 19 & 20 & 21 & 22 & 23 & 24 & 25 & 26 & 27 \\
\hline $\mathrm{SiO}_{2}$ & 55.0 & 54.8 & 51.9 & 49.8 & 51.7 & 51.6 & 56.9 & 51.9 & 52.8 & 52.1 \\
\hline $\mathrm{Al}_{2} \mathrm{O}_{3}$ & 27.8 & 28.6 & 29.1 & 32.1 & 29.5 & 30.3 & 26.1 & 30.0 & 29.2 & 30.1 \\
\hline $\mathrm{FeO}$ & 0.82 & 0.90 & 0.64 & 0.62 & 0.76 & 0.49 & 0.99 & 0.57 & 0.60 & 0.49 \\
\hline $\mathrm{MgO}$ & 0.00 & 0.28 & 0.09 & 0.03 & 0.12 & 0.11 & 0.02 & 0.18 & 0.11 & 0.09 \\
\hline $\mathrm{CaO}$ & 10.9 & 10.2 & 12.8 & 15.2 & 13.0 & 14.0 & 9.3 & 12.8 & 13.1 & 12.9 \\
\hline $\mathrm{Na}_{2} \mathrm{O}$ & 5.13 & 4.96 & 3.95 & 2.71 & 3.95 & 3.70 & 6.00 & 3.85 & 4.14 & 3.95 \\
\hline $\mathrm{K}_{2} \mathrm{O}$ & 0.31 & 0.32 & 0.10 & 0.06 & 0.08 & 0.07 & 0.32 & 0.09 & 0.14 & 0.12 \\
\hline$\Sigma^{2}$ & 100.0 & 100.1 & 98.6 & 100.5 & 99.1 & 100.3 & 99.6 & 99.4 & 100.1 & 99.8 \\
\hline \multicolumn{11}{|c|}{ Cations, Oxygen $=8$} \\
\hline $\mathrm{Si}$ & 2.491 & 2.473 & 2.394 & 2.265 & 2.376 & 2.346 & 2.574 & 2.372 & 2.399 & 2.370 \\
\hline $\mathrm{Al}$ & 1.482 & 1.520 & 1.581 & 1.720 & 1.596 & 1.624 & 1.393 & 1.617 & 1.565 & 1.619 \\
\hline $\mathrm{Fe}$ & 0.031 & 0.034 & 0.025 & 0.024 & 0.029 & 0.019 & 0.037 & 0.022 & 0.023 & 0.019 \\
\hline $\mathrm{Mg}$ & 0.000 & 0.019 & 0.006 & 0.002 & 0.008 & 0.007 & 0.001 & 0.012 & 0.007 & 0.006 \\
\hline $\mathrm{Ca}$ & 0.530 & 0.493 & 0.631 & 0.743 & 0.639 & 0.682 & 0.452 & 0.624 & 0.637 & 0.630 \\
\hline $\mathrm{Na}$ & 0.450 & 0.434 & 0.353 & 0.239 & 0.352 & 0.326 & 0.526 & 0.341 & 0.365 & 0.349 \\
\hline $\mathrm{K}$ & 0.018 & 0.018 & 0.006 & 0.003 & 0.005 & 0.004 & 0.018 & 0.005 & 0.008 & 0.007 \\
\hline$\Sigma$ & 5.002 & 4.993 & 4.995 & 4.996 & 5.005 & 5.007 & 5.002 & 4.993 & 5.005 & 4.999 \\
\hline \multicolumn{11}{|c|}{ Feldspar Components, mol \% } \\
\hline Or & 1.8 & 1.9 & 0.6 & 0.3 & 0.5 & 0.4 & 1.8 & 0.5 & 0.8 & 0.7 \\
\hline $\mathrm{Ab}$ & 45.1 & 45.9 & 35.7 & 24.3 & 35.3 & 32.2 & 52.8 & 35.2 & 36.1 & 35.4 \\
\hline An & 53.1 & 52.2 & 63.7 & 75.4 & 64.2 & 67.4 & 45.4 & 64.3 & 63.1 & 63.9 \\
\hline
\end{tabular}

Legend

\begin{tabular}{|c|c|c|c|c|}
\hline Column & $\begin{array}{c}\text { Sample } \\
\text { (Interval in } \mathrm{cm} \text { ) }\end{array}$ & $\begin{array}{l}\text { Flow } \\
\text { Unit }\end{array}$ & Rock Type & Crystal Analyzed \\
\hline 1 & $430 \mathrm{~A}-4-2,110-118$ & 1 & Hawaiite & Groundmass \\
\hline 2 & $430 \mathrm{~A}-5-1,21-27$ & 1 & Hawaiite & Groundmass \\
\hline 3 & $430 \mathrm{~A}-6-4,07-15$ & 4 & Hawaiite & Phenocryst core \\
\hline 4 & $430 A_{-}-6-4,140-150$ & 5 & Plagioclase tholeitte & Phenocryst core \\
\hline 5 & $432 \mathrm{~A}-2-1,86-92$ & 1 & Alkalic basalt & Phenocryst core \\
\hline 6 & $432 \mathrm{~A}-2-3,37-43$ & 2 & Alkalic basalt & Phenocryst core \\
\hline 7 & $432 \mathrm{~A}-5-2,56-66$ & 3 & Alkalic basalt & $\begin{array}{l}\text { Inclusion in olivine } \\
\quad(\text { Table } 3 \# 3)\end{array}$ \\
\hline 8 & $433 \mathrm{~A}-20-1,30-36$ & 1 & Alkalic basalt & Groundmass \\
\hline 9 & $433 \mathrm{~A}-21-4,129-138$ & 1 & Alkalic basalt & Microphenocryst \\
\hline 10 & 433B-5-2, 61-68 & 1 & Alkalic basalt & Phenocryst core \\
\hline 11 & 433B- $5-3,85-90$ & 2 & Alkalic basalt & Phenocryst core \\
\hline 12 & $433 C-4-1,30-38$ & 2 & Alkalic basalt & $\begin{array}{l}\text { Inclusion in } \\
\text { clinopyroxene }\end{array}$ \\
\hline 13 & $433 \mathrm{C}-10-4,11-17$ & $4 \mathrm{~F}$ & Olivine tholeiite & Ground mass \\
\hline 14 & $433 \mathrm{C}-12-3,57-65$ & 9 & Tholeiite & Microphenocryst \\
\hline 15 & $433 \mathrm{C}-13-2,55-66$ & 10 & Plagioclase tholeiite & Phenocryst rim \\
\hline 16 & $433 \mathrm{C}-14-3,8-15$ & $11 \mathrm{~B}$ & Plagioclase tholeiite & Phenocryst core \\
\hline 17 & $433 \mathrm{C}-15-6,16-31$ & 13 & Tholeiite & Groundmass \\
\hline 18 & $433 \mathrm{C}-22-5,45-52$ & 18 & Plagioclase tholeiite & Groundmass \\
\hline 19 & $433 \mathrm{C}-24-7,133-139$ & 19 & Tholeiitic picrite & Groundmass \\
\hline 20 & $433 \mathrm{C}-28-2,73-80$ & 25 & Plagioclase tholeiite & Phenocryst core \\
\hline 21 & $433 \mathrm{C}-31-1,28-43$ & 27 & $\begin{array}{l}\text { Plagioclase olivine } \\
\text { tholeite }\end{array}$ & Phenocryst core \\
\hline 22 & $433 \mathrm{C}-34-2,103-111$ & 33 & Tholeiitic picrite & Phenocryst core \\
\hline 23 & $433 \mathrm{C}-37-3,79-87$ & 44 & Tholeiite & Microphenocryst \\
\hline 24 & $433 \mathrm{C}-38-1,67-76$ & $45 \mathrm{~B}$ & Olivine tholeiite & Ground mass \\
\hline & $433 C-42-3,11-20$ & 53 & Plagioclase tholeiite & Phenocryst \\
\hline 26 & $433 \mathrm{C}-47-5,92-100$ & 64 & Tholeite & Phenocryst \\
\hline
\end{tabular}


TABLE 3

Representative Olivine Analyses of DSDP Leg 55 (Oxides wt. \%)

\begin{tabular}{|c|c|c|c|c|c|c|c|}
\hline & 1 & 2 & 3 & 4 & 5 & 6 & 7 \\
\hline $\mathrm{SiO}_{2}$ & 36.0 & 39.4 & 39.6 & 39.1 & 39.7 & 38.6 & 39.9 \\
\hline $\mathrm{Al}_{2} \mathrm{O}_{3}$ & 0.04 & 0.17 & 0.12 & 0.10 & 0.10 & 0.00 & 0.09 \\
\hline $\mathrm{FeO}$ & 35.6 & 13.6 & 16.3 & 17.5 & 14.1 & 19.1 & 12.4 \\
\hline $\mathrm{MnO}$ & 0.62 & 0.13 & 0.15 & 0.21 & 0.18 & 0.27 & 0.13 \\
\hline $\mathrm{MgO}$ & 28.6 & 45.6 & 43.8 & 42.8 & 45.5 & 40.8 & 47.0 \\
\hline $\mathrm{CaO}$ & 0.29 & 0.27 & 0.24 & 0.28 & 0.22 & 0.32 & 0.22 \\
\hline $\mathrm{Cr}_{2} \mathrm{O}_{3}$ & 0.05 & 0.05 & 0.07 & 0.02 & 0.07 & 0.02 & 0.10 \\
\hline$\Sigma$ & 101.2 & 99.2 & 100.3 & 100.0 & 99.9 & 99.1 & 99.8 \\
\hline \multicolumn{8}{|c|}{ Cations, Oxygens $=4$} \\
\hline $\mathrm{Si}$ & 0.991 & 0.992 & 0.998 & 0.995 & 0.995 & 0.999 & 0.993 \\
\hline Al & 0.001 & 0.005 & 0.004 & 0.000 & 0.003 & 0.000 & 0.003 \\
\hline $\mathrm{Fe}$ & 0.891 & 0.285 & 0.344 & 0.374 & 0.295 & 0.414 & 0.257 \\
\hline $\mathrm{Mn}$ & 0.014 & 0.003 & 0.003 & 0.005 & 0.004 & 0.006 & 0.003 \\
\hline $\mathrm{Mg}$ & 1.173 & 1.712 & 1.643 & 1.624 & 1.699 & 1.573 & 1.741 \\
\hline $\mathrm{Ca}$ & 0.009 & 0.007 & 0.006 & 0.008 & 0.006 & 0.009 & 0.006 \\
\hline $\mathrm{Cr}$ & 0.001 & 0.001 & 0.001 & 0.000 & 0.001 & 0.000 & 0.002 \\
\hline$\Sigma$ & 3.008 & 3.005 & 3.000 & 3.005 & 3.003 & 3.001 & 3.005 \\
\hline \multicolumn{8}{|c|}{ Olivine Components, Mol \% } \\
\hline$\% \mathrm{Fo}$ & 58.9 & 85.7 & 82.7 & 81.3 & 85.2 & 79.2 & 87.1 \\
\hline \multicolumn{8}{|c|}{ Legend } \\
\hline & Column & $\begin{array}{c}\text { Sa } \\
\text { (Intery }\end{array}$ & $\begin{array}{l}\text { le } \\
\text { in (m) }\end{array}$ & Rock Type & \multicolumn{2}{|c|}{ Crystal Analyzed } & \\
\hline & 1 & $430 \mathrm{~A}-5-$ & $102-115$ & Hawaiite & \multicolumn{3}{|c|}{ Microphenocryst core } \\
\hline & 2 & $432 \mathrm{~A}-3-$ & $120-126$ & Alkalic basalt & \multicolumn{3}{|c|}{ Phenocryst core } \\
\hline & 3 & $432 \mathrm{~A}-5$ & $57-66$ & Alkalic basalt & \multirow{2}{*}{\multicolumn{3}{|c|}{ Phenocryst core }} \\
\hline & 4 & $433 \mathrm{C}-4-1$ & $30-38$ & Alkalic basalt & & & Phenocryst core \\
\hline & 5 & $433 \mathrm{C}-24$ & $133-139$ & Oceanite & \multicolumn{3}{|c|}{ Phenocryst core } \\
\hline & 6 & $433 \mathrm{C}-31$ & $28-34$ & Tholeiite & \multicolumn{3}{|c|}{ Phenocryst core } \\
\hline & 7 & $433 \mathrm{C}-38$ & $67-76$ & Tholeiite & \multicolumn{3}{|c|}{ Phenocryst rim } \\
\hline
\end{tabular}

$\mathrm{Cr}_{2} \mathrm{O}_{3}$ is below detectability limits. Neither $\mathrm{Na}_{2} \mathrm{O}$ nor $\mathrm{MnO}$ correlates with Fs. The total "other" components make up 7 to 13 per cent. The sample contains both ilmenite $\left(\mathrm{Il}_{90}-\mathrm{Il}_{91}\right)$ and titanomagnetite $\left.\mathrm{Mt}_{51}-\mathrm{Mt}_{44}\right)$. Some of the titanomagnetite crystals contain optically resolvable ilmenite exsolution lamallae. Both groundmass and microphenocrysts of olivine $\left(\mathrm{Fo}_{59-61}\right)$ are present. These iron-rich olivines contain about 0.7 weight per cent $\mathrm{MnO}$ and 0.3 per cent $\mathrm{CaO}$.

\section{Sample 430A-6-1, 17-25 cm: Hawaiite}

This sample, from the base of Flow Unit 2, has a trachytic texture consisting of plagioclase $\left(\mathrm{An}_{56} \mathrm{Or}_{2}-\right.$ $\mathrm{An}_{22} \mathrm{Or}_{7}$ ) laths up to $100 \mu \mathrm{m}$ and dispersed tabular or equant plagioclase $\left(\mathrm{An}_{57} \mathrm{Or}_{2}-\mathrm{An}_{43} \mathrm{Or}_{4}\right)$ microphenocrysts (up to $600 \mu \mathrm{m}$ ). The groundmass consists of interstitial clinopyroxene $\left(\mathrm{Wo}_{43} \mathrm{En}_{39} \mathrm{Fs}_{18}-\mathrm{Wo}_{44} \mathrm{En}_{35} \mathrm{Fs}_{20}\right.$; $\mathrm{Al}_{2} \mathrm{O}_{3}=2.2$ to 3.1 wt. $\%$; $\mathrm{TiO}_{2}=1.7$ to 2.9 wt. $\%$; $\mathrm{MnO}=0.22$ to 0.30 wt. $\% ; \mathrm{Na}_{2} \mathrm{O}=0.4$ to 0.6 wt. $\%$; others $=10$ to 14 mole $\%)$, ilmenite $\left(\mathrm{Il}_{92}-\mathrm{Il}_{94}\right)$, titanomagnetite $\left(\mathrm{Mt}_{52}-\mathrm{Mt}_{32}\right)$, and brown clay alteration products, presumably after glass and iddingsite.

\section{Sample 430A-6-3, 52-63 cm: Hawaiite}

This sample from near the base of Flow Unit 3 has trachytic texture, and contains plagioclase $\left(\mathrm{An}_{54} \mathrm{Or}_{2}-\right.$ $\left.\mathrm{An}_{39} \mathrm{Or}_{5}\right)$ up to $100 \mu \mathrm{m}$. The clinopyroxene $\left(\mathrm{Wo}_{44} \mathrm{En}_{36}\right.$ $\mathrm{Fs}_{20}-\mathrm{Wo}_{45} \mathrm{En}_{35} \mathrm{Fs}_{20}$ ) is present as rare granules in the groundmass. They have a small range of compositions: $\mathrm{Al}_{2} \mathrm{O}_{3}=2.5$ to 4.4 wt. $\%, \mathrm{TiO}_{2}=2$ to 3.15 wt. $\%, \mathrm{Na}_{2} \mathrm{O}$ $=0.6$ to 0.8 wt. $\%, \mathrm{MnO}=0.29$ to 0.34 wt. $\%$, undetectable $\mathrm{Cr}_{2} \mathrm{O}_{3}$ and total "other" components range from 11 to 15 per cent. The sample contains equant exsolved titanomagnetite $\left(\mathrm{Mt}_{43}-\mathrm{Mt}_{24}\right)$ and elongate ilmenite $\left(\mathrm{Il}_{96}\right)$.

\section{Sample 430A-6-4, 7-15 cm: Hawaiite}

The sample from the center of Flow Unit 4 has trachytic texture and contains labradorite $\left(\mathrm{An}_{55} \mathrm{Or}_{2}-\mathrm{An}_{51}\right.$ $\mathrm{Or}_{2}$ ) as rare rounded phenocrysts and intergranular clinopyroxene too small to analyze. The sample contains both titanomagnetite $\left(\mathrm{Mt}_{48}-\mathrm{Mt}_{32}\right)$ and ilmenite $\left(\mathrm{Il}_{93}\right)$.

\section{Sample 430-6-4, 140-150 cm: Tholeiite}

This sample is from the single piece of Flow Unit 5 recovered at Hole 430A. The rock is glomeroporphyritic with glomerocrysts of plagioclase, clinopyroxene, and very rare olivine that is totally altered to clays, and plagioclase phenocrysts (up to $1.5 \mathrm{~mm}$ ). Zoning in the plagioclase glomerocrysts is complex, with cores $\left(\mathrm{An}_{80} \mathrm{Or}_{0}-\mathrm{An}_{65} \mathrm{Or}_{1}\right)$ and rims $\left(\mathrm{An}_{75} \mathrm{Or}_{0}-\mathrm{An}_{71} \mathrm{Or}_{1}\right)$. The groundmass plagioclase is more sodic, and ranges in composition from $\mathrm{An}_{59} \mathrm{Or}_{1}$ to $\mathrm{An}_{51} \mathrm{Or}_{2}$. The clinopyroxene phenocryst cores $\left(\mathrm{Wo}_{43} \mathrm{En}_{46} \mathrm{Fs}_{11}-\mathrm{Wo}_{42} \mathrm{En}_{45} \mathrm{Fs}_{13}\right)$ have $\mathrm{Al}_{2} \mathrm{O}_{3}=2$ to 3.3 weight per cent, $\mathrm{TiO}_{2}=0.5$ to 0.9 weight per cent, $\mathrm{Na}_{2} \mathrm{O}=0.3$ to 0.39 weight per cent, $\mathrm{Cr}_{2} \mathrm{O}_{3}$ up to 0.43 weight per cent, $\mathrm{MnO}=0.10$ to 0.18 weight per cent, and total "other" components $=7$ to 13 mole per cent. The clinopyroxene microphenocrysts, groundmass, and phenocryst rims are nearly identical $\left(\mathrm{Wo}_{43} \mathrm{En}_{46} \mathrm{Fs}_{12}\right.$ - $\mathrm{Wo}_{37} \mathrm{En}_{43} \mathrm{Fs}_{20}$ ), with $\mathrm{Al}_{2} \mathrm{O}_{3}=2$ to 4.8 weight per cent, $\mathrm{TiO}_{2}=0.8$ to 1.75 weight per cent, $\mathrm{Na}_{2} \mathrm{O}=0.29$ to 0.37 weight per cent, $\mathrm{Cr}_{2} \mathrm{O}_{3}$ up to 0.33 weight per cent, $\mathrm{MnO}$ $=0.18$ to 0.30 weight per cent, and total "other" components 6 to 22 per cent. Flow Unit 5 contains both titanomagnetite $\left(\mathrm{Mt}_{42}-\mathrm{Mt}_{22}\right)$ and ilmenite $\left(\mathrm{Il}_{93}\right)$. Pyrite is present but rare.

\section{Hole 430A: Summary and Interpretation}

The hawaiites from Flow Units 1 to 4 are very similar in mineral chemistry. Plagioclase compositions range from sodic labradorite and calcic andesine to anorthoclase (See Figure 1c). Pyroxene compositions are more uniform: the total range in compositions is from $\mathrm{Wo}_{43} \mathrm{En}_{40} \mathrm{Fs}_{17}$ to $\mathrm{Wo}_{40} \mathrm{En}_{37} \mathrm{Fs}_{23}$ (See Figure 1a). The clinopyroxene has undetectable $\mathrm{Cr}_{2} \mathrm{O}_{3}$ and rather high $\mathrm{Na}_{2} \mathrm{O}(0.4$ to $0.8 \%) . \mathrm{Al}_{2} \mathrm{O}_{3}$ and $\mathrm{TiO}_{2}$ are variable; the sample with the highest $\mathrm{TiO}_{2}$ content is 430A-5-1, 21-27 $\mathrm{cm}$, which contains the least titanian augite and the sample with the lowest $\mathrm{TiO}_{2}$ content contains the most titanian augite (430A-6-3, 52-63 cm). The "other" components of Papike et al. (1974) are shown in Figure 1b. All four flow units contain both ilmenite and titanomagnetite in grains that are generally exsolved and oxidized (See Figure 1d). Only one analyzed sample (430A$5-2,102-105 \mathrm{~cm})$ contains unaltered olivine $\left(\mathrm{Fo}_{60}\right)$ as microphenocrysts (plotted along the base of Figure 1a).

The tholeiitic basalt that makes up Flow Unit 5 contains plagioclase phenocrysts $\left(\mathrm{An}_{80} \mathrm{Or}_{0}-\mathrm{An}_{65} \mathrm{Or}_{1}\right)$ and groundmass crystals $\left(\mathrm{An}_{59} \mathrm{Or}_{1}-\mathrm{An}_{51} \mathrm{Or}_{2}\right)$, clinopyroxene phenocrysts $\left(\mathrm{Wo}_{43} \mathrm{En}_{46} \mathrm{Fs}_{11}\right.$ to $\left.\mathrm{Wo}_{42} \mathrm{En}_{45} \mathrm{Fs}_{13}\right)$ and groundmass crystals $\left(\mathrm{Wo}_{42} \mathrm{En}_{46} \mathrm{Fs}_{12}\right.$ to $\mathrm{Wo}_{37} \mathrm{En}_{43} \mathrm{Fs}_{20}$ ), ilmenite $\left(\mathrm{Il}_{93}\right)$ and titanomagnetite $\left(\mathrm{Mt}_{42-22}\right)$. No fresh 
TABLE 4

Representative Fe-Ti Oxide Analyses from Leg 55 (Oxides wt. \%)

\begin{tabular}{|c|c|c|c|c|c|c|c|c|c|c|c|c|}
\hline & 1 & 2 & 3 & 4 & 5 & 6 & 7 & 8 & 9 & 10 & 11 & 12 \\
\hline $\mathrm{Al}_{2} \mathrm{O}_{3}$ & 1.45 & 1.35 & 1.43 & 1.38 & 1.03 & 1.30 & 1.66 & 0.71 & 1.67 & 1.27 & 1.88 & 1.48 \\
\hline $\mathrm{TiO}_{2}$ & 17.38 & 19.74 & 27.41 & 19.96 & 24.53 & 9.71 & 25.02 & 25.27 & 25.05 & 22.13 & 23.00 & 22.71 \\
\hline $\mathrm{FeO}$ & 47.76 & 47.35 & 52.35 & 46.55 & 51.54 & 36.01 & 51.70 & 51.07 & 51.70 & 48.65 & 50.81 & 49.99 \\
\hline $\mathrm{Fe}_{2} \mathrm{O}_{3}$ & 33.32 & 28.48 & 15.04 & 28.09 & 21.14 & 48.63 & 18.97 & 19.35 & 18.65 & 25.34 & 21.06 & 21.05 \\
\hline $\mathrm{MnO}$ & 0.44 & 0.50 & 0.60 & 0.42 & 0.61 & 0.54 & 0.61 & 0.55 & 0.49 & 0.42 & 0.41 & 0.52 \\
\hline $\mathrm{MgO}$ & 1.72 & 0.80 & 2.33 & 1.42 & 1.23 & 2.09 & 1.34 & 1.70 & 1.36 & 1.71 & 0.53 & 0.67 \\
\hline $\mathrm{Cr}_{2} \mathrm{O}_{3}$ & 0.00 & 0.03 & 0.09 & 0.00 & 0.00 & 0.04 & 0.00 & 0.00 & 0.00 & 0.07 & 0.00 & 0.74 \\
\hline TOTAL & 98.07 & 98.25 & 99.25 & 97.83 & 100.08 & 98.31 & 99.29 & 98.65 & 98.92 & 99.59 & 97.69 & 97.16 \\
\hline \multicolumn{13}{|c|}{ Cations, Oxygen $=4$} \\
\hline Al & 0.065 & 0.060 & 0.062 & 0.062 & 0.045 & 0.058 & 0.073 & 0.031 & 0.073 & 0.056 & 0.084 & 0.067 \\
\hline $\mathrm{Fe}^{3+}$ & 0.948 & 0.813 & 0.417 & 0.801 & 0.589 & 1.387 & 0.530 & 0.545 & 0.523 & 0.707 & 0.602 & 0.605 \\
\hline $\mathrm{Cr}$ & 0.000 & 0.001 & 0.003 & 0.000 & 0.000 & 0.001 & 0.000 & 0.000 & 0.000 & 0.002 & 0.000 & 0.022 \\
\hline $\mathrm{Ti}$ & 0.494 & 0.563 & 0.759 & 0.569 & 0.683 & 0.277 & 0.699 & 0.712 & 0.702 & 0.618 & 0.657 & 0.653 \\
\hline $\mathrm{Fe}^{2+}$ & 1.383 & 1.502 & 1.613 & 1.475 & 1.596 & 1.141 & 1.605 & 1.599 & 1.611 & 1.510 & 1.614 & 1.598 \\
\hline $\mathrm{Mn}$ & 0.014 & 0.016 & 0.019 & 0.013 & 0.019 & 0.017 & 0.019 & 0.017 & 0.015 & 0.013 & 0.013 & 0.017 \\
\hline $\mathrm{Mg}$ & 0.097 & 0.045 & 0.128 & 0.080 & 0.068 & 0.118 & 0.074 & 0.095 & 0.076 & 0.095 & 0.030 & 0.038 \\
\hline \multicolumn{13}{|c|}{ Magnetite Components, Mol \% } \\
\hline Usp & 52.6 & 58.3 & 86.2 & 60.5 & 72.3 & 27.0 & 74.7 & 77.4 & 75.2 & 66.7 & 67.5 & 67.6 \\
\hline $\mathrm{Mt}$ & 47.4 & 41.7 & 13.8 & 39.5 & 27.7 & 73.0 & 25.3 & 22.6 & 24.8 & 33.3 & 32.5 & 32.4 \\
\hline
\end{tabular}

\begin{tabular}{|c|c|c|c|c|c|c|c|c|c|c|c|c|}
\hline & 13 & 14 & 15 & 16 & 17 & 18 & 19 & 20 & 21 & 22 & 23 & 24 \\
\hline $\mathrm{Al}_{2} \mathrm{O}_{3}$ & 0.21 & 0.20 & 0.19 & 0.16 & 0.19 & 0.22 & 0.20 & 0.24 & 0.29 & 0.30 & 0.21 & 0.26 \\
\hline $\mathrm{TiO}_{2}$ & 49.09 & 49.30 & 49.18 & 48.75 & 50.30 & 49.55 & 47.22 & 50.63 & 51.14 & 49.67 & 48.88 & 48.65 \\
\hline $\mathrm{FeO}^{2}$ & 38.59 & 41.41 & 41.26 & 40.20 & 41.61 & 42.57 & 37.81 & 39.93 & 35.82 & 41.72 & 41.60 & 42.59 \\
\hline $\mathrm{Fe}_{2} \mathrm{O}_{3}$ & 8.39 & 7.43 & 6.86 & 7.69 & 6.04 & 5.70 & 11.09 & 6.41 & 6.84 & 7.42 & 7.73 & 7.14 \\
\hline $\mathrm{MnO}$ & 0.68 & 0.32 & 0.64 & 0.60 & 0.48 & 0.54 & 0.30 & 0.43 & 0.34 & 0.43 & 0.44 & 0.41 \\
\hline $\mathrm{MgO}$ & 2.73 & 1.46 & 1.30 & 1.70 & 1.76 & 0.81 & 2.44 & 2.90 & 5.51 & 1.41 & 1.07 & 0.42 \\
\hline $\mathrm{Cr}_{2} \mathrm{O}_{3}$ & 0.00 & 0.12 & 0.00 & 0.00 & 0.00 & 0.00 & 0.00 & 0.00 & 0.00 & 0.00 & 0.00 & 0.00 \\
\hline TOTAL & 99.69 & 100.23 & 99.43 & 99.10 & 100.37 & 99.39 & 99.06 & 100.53 & 99.95 & 100.94 & 99.94 & 99.47 \\
\hline \multicolumn{13}{|c|}{ Cations, Oxygen $=3$} \\
\hline Al & 0.006 & 0.006 & 0.006 & 0.005 & 0.006 & 0.007 & 0.006 & 0.007 & 0.008 & 0.009 & 0.006 & 0.008 \\
\hline $\mathrm{Fe}^{3+}$ & 0.157 & 0.140 & 0.130 & 0.146 & 0.113 & 0.109 & 0.210 & 0.119 & 0.125 & 0.138 & 0.146 & 0.136 \\
\hline $\mathrm{Cr}$ & 0.000 & 0.002 & 0.000 & 0.000 & 0.000 & 0.000 & 0.000 & 0.000 & 0.000 & 0.000 & 0.000 & 0.000 \\
\hline $\mathrm{Ti}$ & 0.918 & 0.926 & 0.932 & 0.925 & 0.941 & 0.942 & 0.892 & 0.937 & 0.933 & 0.926 & 0.924 & 0.928 \\
\hline $\mathrm{Fe}^{2+}$ & 0.803 & 0.865 & 0.870 & 0.848 & 0.865 & 0.900 & 0.794 & 0.822 & 0.727 & 0.865 & 0.874 & 0.903 \\
\hline $\mathrm{Mn}$ & 0.014 & 0.007 & 0.014 & 0.013 & 0.010 & 0.012 & 0.006 & 0.009 & 0.007 & 0.009 & 0.009 & 0.009 \\
\hline $\mathrm{Mg}$ & 0.101 & 0.054 & 0.049 & 0.064 & 0.065 & 0.031 & 0.091 & 0.106 & 0.199 & 0.052 & 0.040 & 0.016 \\
\hline \multicolumn{13}{|c|}{ Ilmenite Components, Mol \% } \\
\hline Il & 92.0 & 93.0 & 93.4 & 92.6 & 94.3 & 94.5 & 89.5 & 94.0 & 93.7 & 93.0 & 92.6 & 93.1 \\
\hline $\mathrm{Hm}$ & 8.0 & 7.0 & 6.6 & 7.4 & 5.7 & 5.5 & 10.5 & 6.0 & 6.3 & 7.0 & 7.4 & 6.9 \\
\hline
\end{tabular}

Legend

\begin{tabular}{|c|c|c|c|c|}
\hline Column & $\begin{array}{c}\text { Sample } \\
\text { (Interval in } \mathrm{cm}) \\
\end{array}$ & $\begin{array}{l}\text { Flow } \\
\text { Unit } \\
\end{array}$ & Rock Type & Crystal Analyzed \\
\hline 1 & $430 \mathrm{~A}-5-2,102-115$ & 1 & Hawaiite & Groundmass \\
\hline 2 & $430 \mathrm{~A}-6-4,140-150$ & 5 & Tholeiite & Groundmass \\
\hline 3 & $432 \mathrm{~A}-5-2,57-66$ & 3 & Alkalic basalt & Groundmass \\
\hline 4 & $433 \mathrm{~A}-21-4,129-138$ & 1 & Alkalic basalt & Groundmass \\
\hline 5 & $433 C-4-1,30-38$ & 2 & Alkalic basalt & Groundmass \\
\hline 6 & $433 \mathrm{C}-10-4,11-17$ & $4 \mathrm{~F}$ & Olivine tholeiite & Groundmass \\
\hline 7 & $433 C-13-2,55-66$ & 10 & Plagioclase tholeiite & Groundmass \\
\hline 8 & $433 C-22-5,45-52$ & 18 & Plagioclase tholeiite & Groundmass \\
\hline 9 & $433 \mathrm{C}-28-2,73-80$ & 25 & Plagioclase tholeiite & Groundmass \\
\hline 10 & $433 \mathrm{C}-31-1,28-34$ & 27 & Plagioclase tholeiite & Groundmass \\
\hline 11 & $433 C-37-3,79-87$ & 44 & Tholeiite & Groundmass \\
\hline 12 & $433 C-49-2,17-24$ & 66 & Tholeiite & Groundmass \\
\hline 13 & $430 \mathrm{~A}-4-2,110-118$ & 1 & Hawaiite & Groundmass \\
\hline 14 & $430 \mathrm{~A}-6-4,140-150$ & 5 & Tholeiite & Groundmass \\
\hline 15 & 433B-5-2, 61-68 & 1 & Alkalic basalt & Groundmass \\
\hline 16 & $433 \mathrm{C}-4-1,30-38$ & 2 & Alkalic basalt & Groundmass \\
\hline 17 & $433 C-13-2,55-66$ & 10 & Plagioclase tholeiite & Groundmass \\
\hline 18 & $433 C-14-3,08-15$ & $11 \mathrm{~B}$ & Plagioclase tholeiite & Groundmass \\
\hline 19 & $433 C-21-4,07-13$ & 17 & Tholeiite & Groundmass \\
\hline 20 & $433 C-22-5,45-52$ & 18 & Plagioclase tholeiite & Groundmass \\
\hline 21 & $433 C-24-7,133-139$ & 19 & Tholeiite picrite & Groundmass \\
\hline 22 & $433 \mathrm{C}-28-2,73-80$ & 25 & Plagioclase tholeiite & Groundmass \\
\hline 23 & $433 C-37-3,79-87$ & 44 & Tholeiite & Groundmass \\
\hline 24 & $433 C-42-3,11-20$ & 53 & Plagioclase tholeiite & Groundmass \\
\hline
\end{tabular}


TABLE 5

Represnetative Pyroxenes from Holes 430A and 432A (Oxides wt. \%)

\begin{tabular}{|c|c|c|c|c|c|c|c|c|c|c|c|c|c|c|c|c|}
\hline & 1 & 2 & 3 & 4 & 5 & 6 & 7 & 8 & 9 & 10 & 11 & 12 & 13 & 14 & 15 & 16 \\
\hline $\mathrm{SiO}_{2}$ & 49.50 & 50.56 & 50.04 & 50.48 & 49.23 & 50.76 & 50.40 & 47.88 & 49.69 & 52.58 & 50.95 & 48.29 & 50.77 & 50.13 & 49.69 & 46.54 \\
\hline $\mathrm{Al}_{2} \mathrm{O}_{3}$ & 2.66 & 1.82 & 2.04 & 2.39 & 3.00 & 1.75 & 2.18 & 3.11 & 2.55 & 1.99 & 2.88 & 4.81 & 2.18 & 2.88 & 2.83 & 5.25 \\
\hline $\mathrm{FeO}$ & 10.99 & 12.05 & 12.13 & 11.97 & 12.50 & 12.86 & 10.80 & 12.09 & 11.87 & 7.71 & 7.14 & 8.79 & 11.32 & 10.85 & 10.11 & 10.18 \\
\hline $\mathrm{MnO}$ & 0.28 & 0.29 & 0.28 & 0.31 & 0.26 & 0.34 & 0.25 & 0.25 & 0.31 & 0.16 & 0.11 & 0.18 & 0.30 & 0.23 & 0.23 & 0.21 \\
\hline $\mathrm{MgO}$ & 13.38 & 13.13 & 12.91 & 13.60 & 13.40 & 13.20 & 13.41 & 11.73 & 12.34 & 17.04 & 16.18 & 15.14 & 14.51 & 14.33 & 13.27 & 11.50 \\
\hline $\mathrm{CaO}$ & 20.26 & 20.05 & 19.79 & 19.19 & 18.72 & 18.89 & 20.62 & 20.56 & 20.70 & 19.56 & 20.92 & 19.93 & 19.24 & 19.35 & 21.48 & 21.38 \\
\hline $\mathrm{Na}_{2} \mathrm{O}$ & 0.43 & 0.41 & 0.59 & 0.45 & 0.48 & 0.54 & 0.55 & 0.50 & 0.61 & 0.32 & 0.38 & 0.36 & 0.37 & 0.33 & 0.44 & 0.60 \\
\hline $\mathrm{TiO}_{2}$ & 1.95 & 1.36 & 1.63 & 1.75 & 2.16 & 1.04 & 1.71 & 2.40 & $\begin{array}{l}1.99 \\
\text { (1) }\end{array}$ & 0.67 & 0.56 & 1.75 & 1.19 & 1.29 & $\begin{array}{l}1.79 \\
\text {. }\end{array}$ & 3.10 \\
\hline $\mathrm{Cr}_{2} \mathrm{O}_{3}$ & 0.01 & 0.01 & 0.00 & 0.05 & 0.00 & 0.03 & 0.05 & 0.05 & 0.01 & 0.20 & 0.39 & 0.33 & 0.14 & 0.03 & 0.08 & 0.01 \\
\hline TOTAL & 99.46 & 99.68 & 99.41 & 100.19 & 99.75 & 99.41 & 99.97 & 98.57 & 100.07 & 100.23 & 99.51 & 99.58 & 100.02 & 99.42 & 99.92 & 98.77 \\
\hline \multicolumn{17}{|c|}{ Cations, Oxygen $=6$} \\
\hline $\mathrm{Si}$ & 1.872 & 1.913 & 1.899 & 1.894 & 1.860 & 1.922 & 1.877 & 1.894 & 1.845 & 1.927 & 1.880 & 1.794 & 1.900 & 1.882 & 1.866 & 1.773 \\
\hline $\mathrm{Al}^{\mathrm{IV}}$ & 0.119 & 0.081 & 0.091 & 0.106 & 0.134 & 0.078 & 0.114 & 0.97 & 0.141 & 0.073 & 0.120 & 0.206 & 0.096 & 0.118 & 0.125 & 0.227 \\
\hline $\mathrm{Al} V I$ & 0.000 & 0.000 & 0.000 & 0.000 & 0.000 & 0.000 & 0.000 & 0.000 & 0.000 & 0.013 & 0.005 & 0.005 & 0.000 & 0.010 & 0.000 & 0.009 \\
\hline $\mathrm{Fe}^{2+}$ & 0.309 & 0.348 & 0.343 & 0.337 & 0.349 & 0.350 & 0.330 & 0.301 & 0.352 & 0.196 & 0.121 & 0.154 & 0.302 & 0.283 & 0.264 & 0.241 \\
\hline $\mathrm{Fe}^{3+}$ & 0.039 & 0.034 & 0.042 & 0.038 & 0.046 & 0.057 & 0.045 & 0.039 & 0.038 & 0.040 & 0.099 & 0.119 & 0.052 & 0.058 & 0.054 & 0.084 \\
\hline $\mathrm{Mg}$ & 0.754 & 0.740 & 0.730 & 0.760 & 0.755 & 0.745 & 0.695 & 0.751 & 0.673 & 0.931 & 0.890 & 0.838 & 0.809 & 0.802 & 0.743 & 0.653 \\
\hline $\mathrm{Mn}$ & 0.009 & 0.009 & 0.009 & 0.010 & 0.008 & 0.011 & 0.010 & 0.008 & 0.008 & 0.005 & 0.003 & 0.006 & 0.010 & 0.007 & 0.007 & 0.007 \\
\hline $\mathrm{Ti}$ & 0.055 & 0.039 & 0.047 & 0.049 & 0.061 & 0.030 & 0.057 & 0.048 & 0.070 & 0.018 & 0.016 & 0.049 & 0.033 & 0.036 & 0.051 & 0.089 \\
\hline $\mathrm{Cr}$ & 0.000 & 0.000 & 0.000 & 0.001 & 0.000 & 0.001 & 0.000 & 0.001 & 0.002 & 0.006 & 0.011 & 0.010 & 0.004 & 0.001 & 0.002 & 0.000 \\
\hline $\mathrm{Ca}$ & 0.821 & 0.813 & 0.805 & 0.771 & 0.758 & 0.766 & 0.838 & 0.830 & 0.849 & 0.768 & 0.827 & 0.793 & 0.771 & 0.779 & 0.864 & 0.873 \\
\hline $\mathrm{Na}$ & 0.032 & 0.030 & 0.043 & 0.033 & 0.035 & 0.040 & 0.045 & 0.040 & 0.037 & 0.023 & 0.027 & 0.026 & 0.027 & 0.024 & 0.032 & 0.044 \\
\hline
\end{tabular}

\begin{tabular}{|c|c|c|c|c|c|c|c|c|c|c|c|c|c|c|c|c|}
\hline \multicolumn{17}{|c|}{ 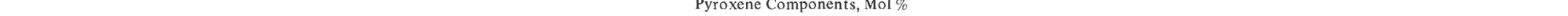 } \\
\hline $\mathrm{Ca}$ & 42.7 & 42.0 & 41.9 & 40.5 & 39.7 & 40.0 & 43.2 & 44.4 & 43.9 & 39.7 & 42.7 & 41.6 & 39.9 & 40.5 & 44.9 & 47.2 \\
\hline $\mathrm{Mg}$ & 39.2 & 38.3 & 38.1 & 39.9 & 39.5 & 38.8 & 39.1 & 35.2 & 36.4 & 48.1 & 45.9 & 44.0 & 41.8 & 41.7 & 38.6 & 35.3 \\
\hline $\mathrm{Fe}_{\mathrm{T}}$ & 18.1 & 19.7 & 20.0 & 19.7 & 20.7 & 21.2 & 17.7 & 20.4 & 19.7 & 12.2 & 11.4 & 14.3 & 18.3 & 17.7 & 16.5 & 17.5 \\
\hline Others & $\begin{array}{l}1.1 \\
11.9\end{array}$ & 8.1 & 9.1 & 10.6 & 13.4 & 8.8 & 11.4 & 9.7 & 14.1 & 7.7 & 13.2 & 20.6 & 9.6 & 11.7 & 12.5 & 22.7 \\
\hline
\end{tabular}

\begin{tabular}{|c|c|c|c|c|c|c|c|c|c|}
\hline & 17 & 18 & 19 & 20 & 21 & 22 & 23 & 24 & 25 \\
\hline $\mathrm{SiO}_{2}$ & 50.02 & 48.38 & 47.97 & 49.54 & 48.28 & 46.34 & 47.97 & 49.54 & 49.93 \\
\hline $\mathrm{Al}_{2} \mathrm{O}_{3}$ & 2.77 & 5.11 & 4.43 & 2.71 & 3.94 & 4.78 & 3.81 & 3.25 & 2.48 \\
\hline $\mathrm{FeO}$ & 9.36 & 9.74 & 11.16 & 14.68 & 11.00 & 12.03 & 9.98 & 10.14 & 11.18 \\
\hline $\mathrm{MnO}$ & 0.16 & 0.13 & 0.16 & 0.27 & 0.23 & 0.29 & 0.17 & 0.22 & 0.25 \\
\hline $\mathrm{MgO}$ & 13.88 & 12.28 & 11.27 & 9.61 & 11.65 & 10.59 & 12.85 & 12.91 & 11.98 \\
\hline $\mathrm{CaO}$ & 21.45 & $\begin{array}{l}21.89 \\
\text {. }\end{array}$ & 21.66 & 20.72 & 21.71 & 21.11 & 21.23 & 21.21 & 20.75 \\
\hline $\mathrm{Na}_{2} \mathrm{O}$ & $\begin{array}{r}1.45 \\
0.39\end{array}$ & $\begin{array}{r}1.09 \\
0.57\end{array}$ & $\begin{array}{r}1.00 \\
0.64\end{array}$ & 0.78 & $\begin{array}{r}1.11 \\
0.59\end{array}$ & 0.65 & 0.60 & $\begin{array}{r}0.49 \\
0.49\end{array}$ & $\begin{array}{r}0.13 \\
0.69\end{array}$ \\
\hline $\begin{array}{l}\mathrm{TiO}_{2} \\
\mathrm{~T}_{2}\end{array}$ & $\begin{array}{l}.397 \\
1.67\end{array}$ & 2.55 & $\begin{array}{l}.04 \\
2.25\end{array}$ & $\begin{array}{l}0.78 \\
1.98\end{array}$ & 2.30 & $\begin{array}{l}3.62 \\
3.25\end{array}$ & $\begin{array}{l}2.60 \\
2.39\end{array}$ & $\begin{array}{l}2.49 \\
2.21\end{array}$ & $\begin{array}{l}1.09 \\
1.80\end{array}$ \\
\hline $\mathrm{Cr}_{2} \mathrm{O}_{3}$ & 0.05 & 0.02 & 0.00 & 0.00 & 0.00 & 0.00 & 0.03 & 0.04 & 0.01 \\
\hline TOTAL & 99.75 & 100.67 & 99.54 & 100.29 & 99.7 & 99.04 & 99.03 & 100.01 & 99.07 \\
\hline \multicolumn{10}{|c|}{ Cations, Oxygen $=6$} \\
\hline $\mathrm{Si}$ & 1.873 & 1.801 & 1.817 & 1.891 & 1.825 & 1.778 & 1.818 & 1.858 & 1.898 \\
\hline $\mathrm{Al}^{\mathrm{IV}}$ & 0.122 & $\begin{array}{l}0.199 \\
\text { a }\end{array}$ & 0.183 & 0.109 & 0.175 & 0.216 & 0.170 & 0.142 & 0.102 \\
\hline $\mathrm{Al} V \mathrm{VI}$ & 0.000 & 0.025 & 0.015 & 0.013 & 0.001 & 0.000 & 0.000 & 0.002 & 0.010 \\
\hline $\mathrm{Fe}^{2+}$ & 0.238 & 0.232 & 0.267 & 0.430 & 0.261 & 0.309 & 0.239 & $\begin{array}{l}0.0268 \\
0.268\end{array}$ & 0.316 \\
\hline $\mathrm{Fe}^{3+}$ & 0.055 & 0.072 & 0.087 & 0.039 & 0.087 & 0.077 & 0.077 & 0.050 & 0.040 \\
\hline $\mathrm{Mg}$ & 0.774 & 0.681 & 0.636 & 0.547 & 0.656 & 0.606 & 0.726 & 0.722 & 0.679 \\
\hline $\mathrm{Mn}$ & 0.005 & 0.004 & 0.005 & 0.009 & 0.007 & 0.009 & 0.005 & 0.007 & 0.008 \\
\hline $\mathrm{Ti}$ & 0.047 & 0.071 & 0.064 & 0.057 & 0.065 & 0.094 & 0.068 & 0.062 & 0.051 \\
\hline $\mathrm{Cr}$ & 0.001 & 0.001 & $\begin{array}{l}0.000 \\
0.000\end{array}$ & 0.000 & 0.000 & 0.000 & 0.001 & 0.001 & 0.000 \\
\hline $\mathrm{Ca}$ & 0.861 & 0.873 & 0.879 & 0.848 & 0.879 & 0.868 & 0.862 & 0.852 & 0.845 \\
\hline $\mathrm{Na}$ & 0.028 & 0.041 & 0.047 & 0.058 & 0.043 & 0.048 & 0.044 & 0.036 & 0.051 \\
\hline \multicolumn{10}{|c|}{ Pyroxene Components, Mol $\%$} \\
\hline $\mathrm{Ca}$ & 44.6 & 47.0 & 47.0 & 45.5 & 46.7 & 46.7 & 45.3 & 45.0 & 45.0 \\
\hline $\mathrm{Mg}$ & 40.2 & 36.7 & 34.0 & 29.4 & 34.9 & 32.6 & 38.1 & 38.1 & 36.1 \\
\hline $\mathrm{FeT}_{\mathrm{T}}$ & 15.2 & 16.3 & 18.9 & 25.2 & 18.5 & 20.8 & 16.6 & 16.8 & 18.9 \\
\hline Others & 12.2 & 19.9 & 18.3 & 10.9 & 17.5 & 21.6 & 17.0 & 14.2 & 102 \\
\hline
\end{tabular}

Legend

$\frac{\text { Rock Type }}{\text { Hawaiite }}$

Hawaiite

Hawaiite

Hawaiite

Hawaiite

Hawaiite

Plagioclase tholeii

lagioclase tholeiite

Plagioclase tholeiite
Plagioclase tholeiite

Plagioclase tholeiite

Alkali basal

Alkali basal

Alkali basalt

Alkall basal

Alkali basalt

li basalt

Alkali basalt
Crystal Analyzed

\section{Groundmass}

Groundmass

Groundmass

Ground mass

Groundmass

Groundmass

Pround mass

Phenocryst core

Phenocryst rim

Phenocryst rim

Microphenocryst core Microphenocryst rím

Groundmass

Ground mass

Ground mas

Ground mass

Microphenocryst core Groundmass 
TABLE 6

Hole 430A, Mineralogy Summary Table

\begin{tabular}{|c|c|c|c|c|c|c|}
\hline \multirow{2}{*}{$\begin{array}{c}\text { Sample } \\
\text { (Interval in cm) } \\
\text { (F.U., Rock Type) }\end{array}$} & \multirow[b]{2}{*}{$\begin{array}{l}\text { Olivine }(\mathrm{Fo})^{\mathrm{a}} \\
\text { Temp. }\left({ }^{\circ} \mathrm{C}\right)\end{array}$} & \multirow[b]{2}{*}{$\begin{array}{c}\text { Plagioclase }(\mathrm{An})^{\mathrm{b}} \\
\text { Temp. }\left({ }^{\circ} \mathrm{C}\right)\end{array}$} & \multirow[b]{2}{*}{$\begin{array}{l}\text { Pyroxene } \\
\text { Wo-En-Fs }\end{array}$} & \multicolumn{3}{|c|}{ Opaques } \\
\hline & & & & $\begin{array}{c}\text { Mt } \\
\text { Temp. }\left({ }^{\circ} \mathrm{C}\right)\end{array}$ & $\begin{array}{c}\mathrm{I} 1 \\
\log \mathrm{fO}_{2}\end{array}$ & Chrome Spinel \\
\hline $\begin{array}{l}430 \mathrm{~A}-4-2,110-118 \\
(1, \text { Hawaiite) }\end{array}$ & & $\begin{array}{l}\mathrm{G}^{\mathrm{b}} 54 \text { to } 6 \\
1135^{\circ} \text { to } 1010^{\circ}\end{array}$ & & $\begin{array}{c}30 \text { to } 37 \\
1000^{\circ}-960^{\circ}\end{array}$ & $\begin{array}{c}78 \text { to } 92 \\
-11 \text { to }-12\end{array}$ & none \\
\hline $\begin{array}{l}\text { 430A-5-1, 21-27 } \\
\text { (1, Hawaiite) }\end{array}$ & & $\begin{array}{l}\mathrm{G} 48 \text { to } 11 \\
1110^{\circ} \text { to } 1010^{\circ}\end{array}$ & $\mathrm{G} 43-40-17$ to $42-37-21$ & $\begin{array}{l}56 \\
990^{\circ}\end{array}$ & $\begin{array}{r}86 \\
-10\end{array}$ & none \\
\hline $\begin{array}{l}\text { 430A-5-2, 102-i } 15 \\
(1, \text { Hawaiite) }\end{array}$ & $\begin{array}{c}61-59(80) \\
1177^{\circ}-1167^{\circ}\end{array}$ & & G42-40-18 to $40-37-23$ & $\begin{array}{l}44 \text { to } 51 \\
970^{\circ}-890^{\circ}\end{array}$ & $\begin{array}{c}90 \text { to } 91 \\
-11 \text { to }-12\end{array}$ & none \\
\hline $\begin{array}{l}430 \mathrm{~A}-6-1,17-25 \\
(2, \text { Hawaiite })\end{array}$ & & $\begin{array}{c}\mathrm{P} 57 \text { to } \mathrm{G} 22 \\
1179^{\circ} \text { to } 1040^{\circ}\end{array}$ & G43-39-18 to $44-35-20$ & $\begin{array}{l}32 \text { to } 52 \\
980^{\circ}-850^{\circ}\end{array}$ & $\begin{array}{c}92 \text { to } 94 \\
-11 \text { to }-13\end{array}$ & none \\
\hline $\begin{array}{l}430 \mathrm{~A}-6-3,52-63 \\
\text { (3, Hawaiite) }\end{array}$ & & $\begin{array}{c}\mathrm{G} 54 \text { to } 39 \\
1148^{\circ} \text { to } 1067^{\circ}\end{array}$ & G44-36-20 to $45-35-20$ & $\begin{array}{l}24 \text { to } 43 \\
870^{\circ}-720^{\circ}\end{array}$ & $\begin{array}{c}96 \\
-14 \text { to }-17\end{array}$ & none \\
\hline $\begin{array}{l}430 \mathrm{~A}-6-4,7-15 \\
\text { (4, Hawaiite) }\end{array}$ & & $\begin{array}{c}\mathrm{P} 55 \text { to } 51 \\
1163^{\circ} \text { to } 1134^{\circ}\end{array}$ & & $\begin{array}{l}32 \text { to } 48 \\
970^{\circ}-870^{\circ}\end{array}$ & $\begin{array}{c}93 \\
-12 \text { to }-13\end{array}$ & none \\
\hline \multirow[t]{2}{*}{$\begin{array}{l}430 \mathrm{~A}-6-4,140-150 \\
\text { (5, Plag. thol) }\end{array}$} & & $\begin{array}{c}\text { P80 to } 65 \\
1400^{\circ}-1161^{\circ}\end{array}$ & P43-46-11 to G37-43-20 & $\begin{array}{l}22 \text { to } 42 \\
1070^{\circ}-930^{\circ}\end{array}$ & $\begin{array}{c}93 \\
-10 \text { to }-12\end{array}$ & none \\
\hline & & $\begin{array}{c}\mathrm{G} 59 \text { to } 51 \\
1117^{\circ}-1068^{\circ}\end{array}$ & & & & \\
\hline
\end{tabular}

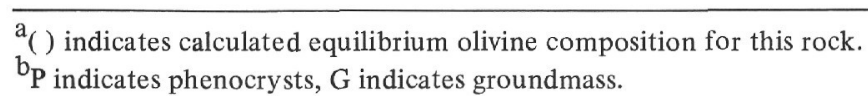

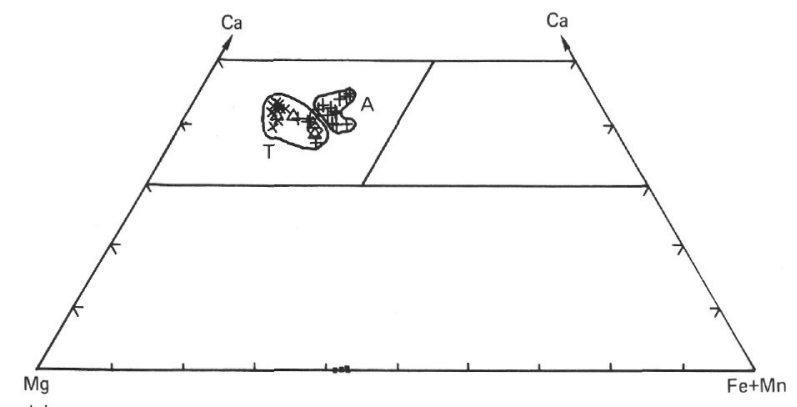

(a)

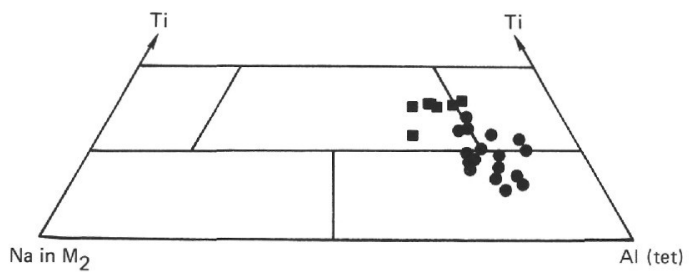

(b)

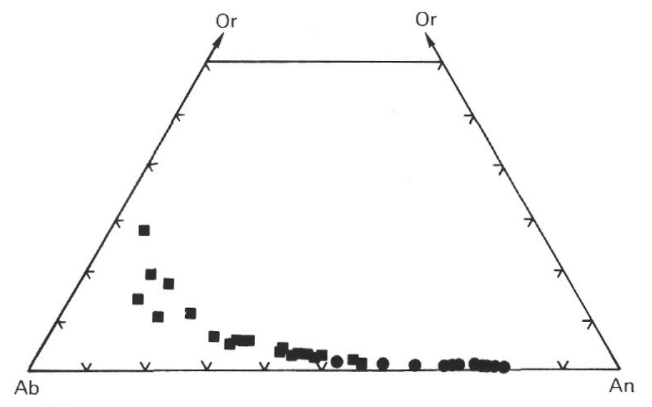

(c)

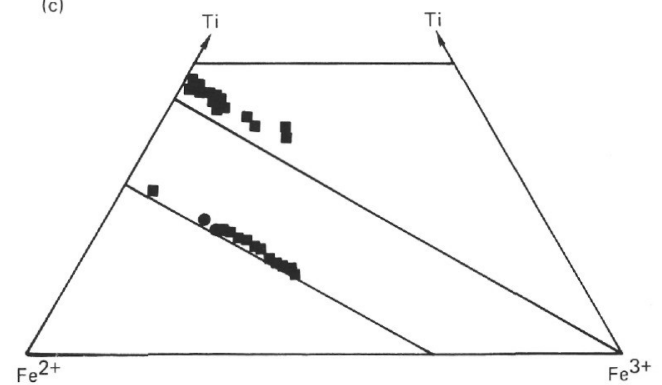

(d)

Figure 1. Mineralogy of Hole 430A basalts. (a) Quadrilateral components of clinopyroxene. The forsterite content of olivine in Sample 430A-5-2, 102-115 cm is plotted along the En-Fs join. Symbols are groundmass $(+)$, phenocryst core $(\times)$, phenocryst rim $(\triangle)$, microphenocryst core $(\gg)$, and microphenocryst rim ( $\square)$. The pyroxenes form tholeiitic basalt Sample 430A-6-4, 140-150 cm are enclosed and labelled T; those from the overlying four hawaite flows are labelled A. (b) "Other" components of clinopyroxene in tholeiitic basalts (circles) and hawaiites (squares). (c) Anorthite, albite, orthoclase components of tholeiitic basalts (circles) and hawaiites (squares). (d) $\mathrm{Ti}^{4+}, \mathrm{Fe}^{2+}, \mathrm{Fe}^{3+}$ of opaque oxides. The analyses are not on the Usp-Mt and IlmHem joins, because components containing $\mathrm{Mg}$ and Mn are ignored. Tholeiites (circles); hawaiites (squares). 
olivine was observed. The plagioclase, pyroxene, and $\mathrm{Fe}-\mathrm{Ti}$ oxide compositions are shown in Figures 1a through $1 \mathrm{~d}$.

The most calcic groundmass plagioclase in Flow 1 (Samples 430A-4-2, 110-118 cm, 430A-5-1, 21-27 cm, and $430 \mathrm{~A}-5-2,102-115 \mathrm{~cm}$ ) is $\mathrm{An}_{54}$. This composition gives a calculated crystallization temperature of $1135^{\circ} \mathrm{C}$ when geothermometer \#8 of Drake (1976) is used. This assumes that the liquid composition is that of the bulk rock (see Table 2 in Kirkpatrick et al., this volume).

The olivine $\left(\mathrm{Fo}_{60}\right)$ cannot have crystallized from a liquid of the bulk composition of the rock assuming $K_{D}=$ 0.30 , where $K_{D}=\left(\mathrm{FeO}_{\mathrm{OL}} / \mathrm{MgO}_{\mathrm{OL}}\right)\left(\mathrm{MgO}_{\mathrm{L}} / \mathrm{FeO}_{\mathrm{L}}\right)$ (Roeder and Emslie, 1970). The olivine saturation surface of Roeder and Emslie (1970) indicates that olivine $\left(\mathrm{Fo}_{75}\right)$ should start to crystallize from this basalt at $1140^{\circ} \mathrm{C}$. Since the most forsteritic microphenocryst in this basalt is $\mathrm{Fo}_{61}$, the calculated initial olivine $\left(\mathrm{Fo}_{75}\right)$ must have re-equilibrated with the magma as it cooled.

The Buddington-Lindsley (1964) geothermometer based on coexisting ilmenite and magnetite indicates that the opaques equilibrated at 1000 to $890^{\circ} \mathrm{C}$ under oxygen fugacities of $10^{-10}$ to $10^{-11}$ atmospheres. These temperatures and oxygen fugacities lie on the FMQ buffer.

Hawaiite Flow Units 2 and 3, Samples 430A-6-1, $17-25 \mathrm{~cm}$ and $430 \mathrm{~A}-6-3,52-63 \mathrm{~cm}$, respectively, are chemically and texturally similar to Flow 1 . The crystallization temperatures of the most calcic groundmass plagioclase $\left(\mathrm{An}_{56}\right)$ in Flows 2 and 3 are about the same as that in Flow 1.

The core compositions of the plagioclase phenocrysts $\left(\mathrm{An}_{80}\right)$ in Sample 430A-6-1, 140-150 cm do not appear to have crystallized from a melt with the same composition as the whole rock, since the calculated plagioclase crystallization temperature is $1400^{\circ} \mathrm{C}$. This temperature is well above the expected liquidus temperature of about $1170^{\circ} \mathrm{C}$ for an oceanic island tholeiite with $\mathrm{Mg} \#=0.50$ (Thompson and Tilley, 1969). The feldspar groundmass appears to have crystallized over a temperature range of 1070 to $1120^{\circ} \mathrm{C}$, similar to the range of feldspar crystallization in the hawaiite flows. The plagioclase phenocrysts, therefore, probably crystallized from a magma different in composition from that of the host tholeiite, while the groundmass feldspar could have crystallized from a magma of the composition of the tholeiite.

The paragenetic sequence of tholeiitic Flow Unit 5, as determined from textural and phase compositional relationships, is olivine (now altered), plagioclase, and clinopyroxene, followed by groundmass plagioclase and pyroxene. The crystallization sequence in the hawaiite Flow Units 1 through 4 appears to be plagioclase $\left(\mathrm{An}_{55}\right)$ phenocrysts, olivine microphenocrysts $\left(\mathrm{Fo}_{60}\right)$, followed by groundmass plagioclase, pyroxene, and $\mathrm{Fe}-\mathrm{Ti}$ oxides.

Plagioclase and pyroxene compositions have been associated with the various volcanic eruptive stages on Maui: (1) shield-building, (2) post-caldera or alkalic stage, and (3) post-erosional or nephelinic stage, (Keil et al., 1972, Fodor et al., 1975). The hawaiite flow units (1 through 4) from Ōjin Seamount have groundmass feldspar $\left(\mathrm{An}_{56} \mathrm{Or}_{2}-\mathrm{An}_{6} \mathrm{Or}_{27}\right)$ intermediate between the feld- spar in the hawaiites and mugearites of the alkalic eruption stage (Keil et al., 1972). The pyroxenes in the Öjin hawaiites ( $\left.\mathrm{Wo}_{43} \mathrm{En}_{40} \mathrm{Fs}_{17}-\mathrm{Wo}_{40} \mathrm{En}_{37} \mathrm{Fs}_{23}\right)$ are similar to those of the alkalic basalts or hawaiites of Maui (Fodor et al., 1975).

The basalt we classify as tholeiite on the basis of major-element chemistry has groundmass plagioclase $\left(\mathrm{An}_{59} \mathrm{Or}_{1}-\mathrm{An}_{51} \mathrm{Or}_{2}\right)$ that is most similar to plagioclase from alkalic basalts of Maui and unlike the groundmass plagioclase $\left(\mathrm{An}_{66} \mathrm{Or}_{1}-\mathrm{An}_{62} \mathrm{Or}_{1}\right)$ of Maui tholeiites (Keil et al., 1972). Keil et al. (1972) note, however, that the plagioclase phenocrysts in the tholeiitic basalts show little zoning (between 5 and $9 \% \mathrm{An}$ ), whereas phenocrysts in alkalic basalts generally have sodic rims similar in composition to the groundmass plagioclase. The rims of phenocrysts in Sample 430A-6-4, 140-150 cm overlap in composition with the phenocryst cores; none of the rims approach the composition of the groundmass plagioclase. Keil et al. (1972) also indicate that the groundmass plagioclase composition is lower in tholeiitic basalts containing phenocrysts of plagioclase than in those that are phenocryst-free. We suggest that the rather low An content of the groundmass plagioclase in Sample 430A-6-4, 140-150 cm reflects the high abundance of calcic plagioclase phenocrysts, and that the sample is indeed a tholeiitic basalt of the shield-building stage. Groundmass pyroxene from this flow is chemically transitional between pyroxene in the tholeiitic and in the alkalic flows of Maui. The large range of groundmass compositions $\left(\mathrm{Fs}_{12-20}\right)$ is consistent with the large intra-rock compositional variation observed only in tholeiitic basalts (Fodor et al., 1975). We conclude that Sample 430A-6-4, 140-150 cm from Flow Unit 5 is a tholeiitic basalt of the shield-building eruptive stage, as indicated by major- and trace-element chemistry (Kirkpatrick et al., this volume). The similarity between the compositions in this tholeiite and those in alkalic basalts may be related to similar conditions of cooling and crystal growth rather than to whole-rock chemistry.

\section{RESULTS: NINTOKU SEAMOUNT, SITE 432}

Representative analyses of plagioclase, olivine, ilmenite and magnetite, and clinopyroxene are presented in Tables 2, 3, 4, and 5, respectively. The analyses are plotted in Figure 2. The compositional data and calculated equilibration temperatures are summarized in Table 7.

\section{Sample 432A-2-1, 86-92 cm: Alkalic Basalt}

This sample, from near the top of Flow Unit 1, has a diabasic texture consisting of plagioclase phenocrysts $\left(\mathrm{An}_{70} \mathrm{Or}_{1}-\mathrm{An}_{46} \mathrm{Or}_{2}\right)$ up to $2 \mathrm{~mm}$; microphenocrysts of olivine altered to clays; clinopyroxene microphenocrysts with pale brown cores $\left(\mathrm{Wo}_{45} \mathrm{En}_{40} \mathrm{Fs}_{15}-\mathrm{Wo}_{45} \mathrm{En}_{36} \mathrm{Fs}_{19}\right)$ and purple-tinted rims $\left(\mathrm{Wo}_{47} \mathrm{En}_{35} \mathrm{Fs}_{17}-\mathrm{Wo}_{46} \mathrm{En}_{34} \mathrm{Fs}_{19}\right)$; groundmass plagioclase $\left(\mathrm{An}_{60} \mathrm{Or}_{1}-\mathrm{An}_{18} \mathrm{Or}_{9}\right)$; groundmass clinopyroxene $\left(\mathrm{Wo}_{44} \mathrm{En}_{40} \mathrm{Fe}_{15}-\mathrm{Wo}_{46} \mathrm{En}_{29} \mathrm{Fs}_{25}\right)$; equant grains of titanomagnetite $\left(\mathrm{Mt}_{18}-\mathrm{Mt}_{5}\right)$; and rare pyrite. Some plagioclase phenocrysts contain abundant glass inclusions up to $10 \mu \mathrm{m}$, and all phenocrysts are reverse-zoned. Clinopyroxene microphenocrysts and groundmass have "other" components $=9-29$ mole per 

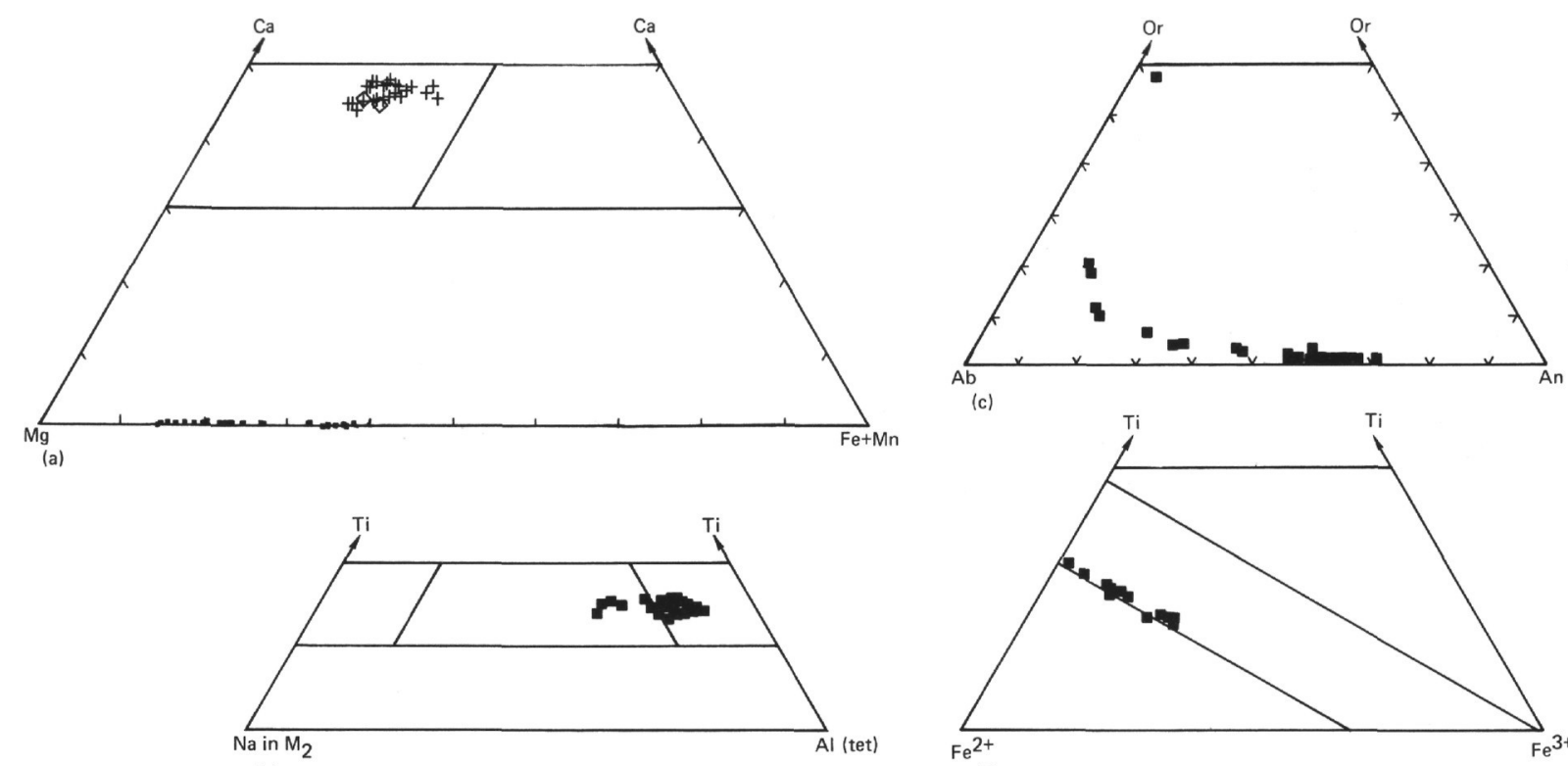

(b)

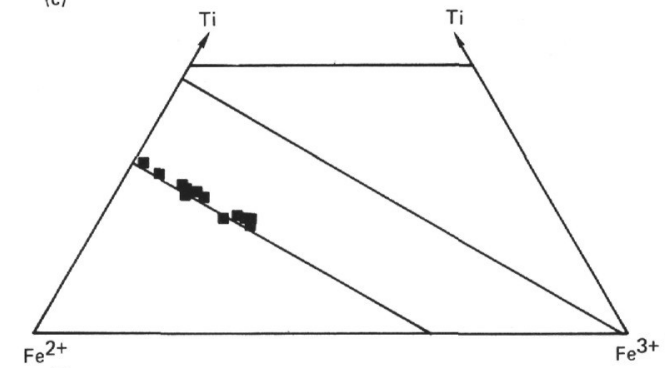

(d)

Figure 2. Mineralogy of Hole $432 \mathrm{~A}$ basalts (all alkalic). (a) Quadrilateral components of clinopyroxene. The fosterite content of olivine is plotted along the Fs-En join. Symbols as in Figure la. (b) "Other", components of clinopyroxene. (c) Anorthite, albite, and orthoclase components of feldspar. (d) $\mathrm{Ti}^{4+}, \mathrm{Fe}^{2+}$, and $\mathrm{Fe}^{3+}$ ternary plot of the opaque oxides. No oxides in the ilmenite-hematite series were observed.

TABLE 7

Hole 432A, Mineralogy Summary Table

\begin{tabular}{|c|c|c|c|c|c|c|}
\hline \multirow{2}{*}{$\begin{array}{c}\text { Sample } \\
\text { (Interval in cm) } \\
\text { (F.U., Rock Type) }\end{array}$} & \multirow[b]{2}{*}{$\begin{array}{l}\text { Olivine }(\mathrm{Fo})^{\mathrm{a}} \\
\text { Temp. }\left({ }^{\circ} \mathrm{C}\right)\end{array}$} & \multirow[b]{2}{*}{$\begin{array}{c}\text { Plagioclase }(\mathrm{An})^{\mathrm{b}} \\
\text { Temp. }\left({ }^{\circ} \mathrm{C}\right)\end{array}$} & \multirow[b]{2}{*}{$\begin{array}{l}\text { Pyroxene } \\
\text { Wo-En-Fs }\end{array}$} & \multicolumn{3}{|c|}{ Opaques } \\
\hline & & & & $\begin{array}{c}\text { Mt } \\
\text { Temp. }\left({ }^{\circ} \mathrm{C}\right)\end{array}$ & $\underset{\log \mathrm{fO}_{2}}{\mathrm{Il}}$ & Chrome Spinel \\
\hline \multirow[t]{2}{*}{$\begin{array}{l}432 \mathrm{~A}-2-1,86-92 \\
\text { (1, Alk. bas.) }\end{array}$} & & $\begin{array}{c}\text { P70 to } 46 \\
1254^{\circ}-1060^{\circ}\end{array}$ & G45-40-15 to $46-29-25$ & 5 to 18 & none & none \\
\hline & & $\begin{array}{r}\mathrm{G} 60 \text { to } 18 \\
1148^{\circ}-971^{\circ}\end{array}$ & & & & \\
\hline \multirow[t]{2}{*}{$\begin{array}{l}\text { 432A-2-3, 37-43 } \\
(2, \text { Alk. bas.) }\end{array}$} & & $\begin{array}{r}\mathrm{P} 65 \text { to } 11 \\
1178^{\circ}-965^{\circ}\end{array}$ & G47-36-17 to $47-32-21$ & 12 to 18 & none & none \\
\hline & & $\begin{array}{c}\text { G5 } 8 \text { to } 4 \\
1122^{\circ}-928^{\circ}\end{array}$ & & & & \\
\hline $\begin{array}{l}432 \mathrm{~A}-3-2,120-126 \\
(3, \text { Alk. bas.) }\end{array}$ & $\begin{array}{c}87-55(80) \\
1213^{\circ}-1131^{\circ}\end{array}$ & $\begin{array}{l}\text { P56 to } \mathrm{G} 46 \\
1065^{\circ} \text { to } 1000^{\circ}\end{array}$ & & 27 to 35 & none & none \\
\hline $\begin{array}{l}432 \mathrm{~A}-5-2,57-66 \\
(3, \text { Alk. bas.) }\end{array}$ & $\begin{array}{c}85-50(80) \\
1267^{\circ}-1134^{\circ}\end{array}$ & $\begin{array}{l}\mathrm{G} 62 \text { to } 11 \\
1174^{\circ} \text { to } 1015^{\circ}\end{array}$ & G45-38-17 to $45-36-19$ & 12 to 17 & none & none \\
\hline
\end{tabular}

$\mathrm{a}$ ( ) indicates calculated equilibrium olivine composition for this rock.

${ }^{\mathrm{b}} \mathrm{P}$ indicates phenocryst, $\mathrm{G}$ indicates groundmass.

cent; $\mathrm{TiO}_{2}$ up to 3.7 wt. per cent; $\mathrm{Al}_{2} \mathrm{O}_{3}$ up to 6.5 wt. per cent; $\mathrm{Na}_{2} \mathrm{O}=0.4$ to 0.8 wt. per cent; and $\mathrm{Cr}_{2} \mathrm{O}_{3}$ less than 0.02 wt. per cent.

\section{Sample 432A-2-3, 37-43 cm: Alkalic Basalt}

This sample, from near the base of Flow Unit 2, has a diabasic texture consisting of plagioclase phenocrysts $\left(\mathrm{An}_{65} \mathrm{Or}_{1}-\mathrm{An}_{11} \mathrm{Or}_{20}\right)$; microphenocrysts of olivine completely altered to iddingsite; groundmass plagioclase $\left(\mathrm{An}_{58} \mathrm{Or}_{1}-\mathrm{An}_{4} \mathrm{Or}_{57}\right)$; intergranular groundmass clinopyroxene $\left(\mathrm{Wo}_{47} \mathrm{En}_{36} \mathrm{Fs}_{17}-\mathrm{Wo}_{47} \mathrm{En}_{32} \mathrm{Fs}_{21}, \mathrm{Al}_{2} \mathrm{O}_{3}=3.5-\right.$ 5.7 wt. $\%, \mathrm{TiO}_{2}=2.3-3.6$ wt. $\%, \mathrm{Na}_{2} \mathrm{O}=0.56-0.74$ wt. $\%, \mathrm{Cr}_{2} \mathrm{O}_{3}$ less than 0.02 wt. \%, "others" = 16-26 mole \%); and equant grains of titanomagnetite $\left(\mathrm{Mt}_{12}\right.$ $\mathrm{Mt}_{18}, \mathrm{MnO}=0.6-1.1 \mathrm{wt} . \%$ ). The plagioclase phenocrysts contain glass inclusions, and one grain shows kink banding resulting from deformation. In the clinopyroxene, $\mathrm{Al}_{2} \mathrm{O}_{3}$ and $\mathrm{TiO}_{2}$ correlate inversely with $\mathrm{SiO}_{2}$.

\section{Sample 432A-3-2, 120-126 cm: Alkalic Basalt}

This sample, from within 2 meters of the top of Flow Unit 3, has an intergranular texture consisting of olivine phenocrysts $\left(\mathrm{Fo}_{86}-\mathrm{Fo}_{87}\right)$ up to $1.5 \mathrm{~mm}$; olivine microphenocrysts $\left(\mathrm{Fo}_{66}-\mathrm{Fo}_{59}\right)$ up to $0.3 \mathrm{~mm}$, partially altered to 
iddingsite; rare plagioclase microphenocrysts $\left(\mathrm{An}_{56} \mathrm{Or}_{2}\right)$; groundmass plagioclase $\left(\mathrm{An}_{55} \mathrm{Or}_{2}-\mathrm{An}_{46} \mathrm{Or}_{2}\right)$ and clinopyroxene (not analyzed); equant titanomagnetite $\left(\mathrm{Mt}_{35^{-}}\right.$ $\mathrm{Mt}_{27}, \mathrm{MnO}=0.6-0.7$ wt. $\%, \mathrm{MgO}=2.2-3.0$ wt. \%); and rare pyrite and calcopyrite.

\section{Sample 432A-5-2, 57-66 cm: Alkalic Basalt}

This sample, recovered at 19 meters into Flow Unit 3, has an ophitic texture and contains olivine phenocrysts and microphenocrysts $\left(\mathrm{Fo}_{85}-\mathrm{Fo}_{50}\right)$ up to $2 \mathrm{~mm}$ and a groundmass of plagioclase laths $\left(\mathrm{An}_{62} \mathrm{Or}_{2}-\mathrm{An}_{11} \mathrm{Or}_{21}\right)$ and titanomagnetite $\left(\mathrm{Mt}_{17}-\mathrm{Mt}_{12}, \mathrm{MnO}=0.6-1.3\right.$ wt. $\%$ and $\mathrm{Cr}_{2} \mathrm{O}_{3}$ up to 0.4 wt. \%) in ophitic pale brown to mauve clinopyroxene $\left(\mathrm{Wo}_{46} \mathrm{En}_{38} \mathrm{Fs}_{16}-\mathrm{Wo}_{45} \mathrm{En}_{36} \mathrm{Fs}_{19}\right.$; "others" = 10-17 mole \% and $\mathrm{Cr}_{2} \mathrm{O}_{3}<0.02$ wt. \%). In this pyroxene, $\mathrm{Al}_{2} \mathrm{O}_{3}$ decreases and $\mathrm{Na}_{2} \mathrm{O}$ increases with increasing iron. Tiny rare elongate grains, possibly ilmenite, and pyrite are also present in the groundmass.

\section{Hole 432A Summary and Interpretation}

The mineralogy of all three alkalic basalt flows is quite similar and is summarized in Table 7. All three flow units contain phenocrysts of plagioclase and olivine. Flow Units 1 and 2 have much more plagioclase than olivine (completely altered); Flow Unit 3 has more olivine than plagioclase (no plagioclase phenocrysts are present in the polished probe section). All three flows contain clinopyroxene with high $\mathrm{TiO}_{2}, \mathrm{Al}_{2} \mathrm{O}_{3}$, and $\mathrm{Na}_{2} \mathrm{O}$ contents, and undetectable $\mathrm{Cr}_{2} \mathrm{O}_{3}$. All three flows contain titanomagnetite but very rare or no ilmenite. The analyses of plagioclase, clinopyroxene and olivine, and titanomagnetite are shown in Figure 2.

Textural relations indicate that the three flows have similar crystallization histories, in which olivine and plagioclase crystallized together. The groundmass plagioclase equilibrated with the magma at temperatures around $1175^{\circ} \mathrm{C}$ to below $1000^{\circ} \mathrm{C}$. Some of the plagioclase phenocrysts in Flow Units 1 and 2 contain abundant glass inclusions or pockets of groundmass crystals, and are resorbed or deformed. These crystals have reverse zoning, with $\mathrm{An}_{57}$ cores and more calcic rims. The olivine phenocrysts in Flow Unit $\mathbf{3}$ are more forsteritic than the calculated equilibrium olivine, as well. We suggest that both the olivine and the plagioclase cores are xenocrysts not in equilibrium with the magma.

We can use the groundmass mineral compositions to try to determine during which eruptive stage - the postcaldera alkalic or the post-erosional nephelinic - these alkalic basalts erupted. The groundmass plagioclase in these basalts $\left(\mathrm{An}_{62} \mathrm{Or}_{1}-\mathrm{An}_{4} \mathrm{Or}_{57}\right)$ is similar to that found in hawaiites of the Maui alkalic eruptive stage (Keil et al., 1972), and is far less calcic than that in the posterosional alkalic basalts $\left(\mathrm{An}_{70} \mathrm{Or}_{1.3-2.1}\right)$. Groundmass clinopyroxene chemistry in these basalts is within the range of the compositions found for alkalic basalts of the alkalic stage, but also very close to the compositions for clinopyroxenes in post-erosional alkalic basalts (Fodor et al., 1975). The high $\mathrm{TiO}_{2}, \mathrm{Al}_{2} \mathrm{O}_{3}$, and $\mathrm{Na}_{2} \mathrm{O}$ contents in these groundmass pyroxenes overlap the compositional ranges of pyroxenes from the posterosional nephelinic suite and the post-caldera alkalic suite. The type of rock having pyroxenes most similar to those in Flow Units 1 through 3 is hawaiite from the alkalic eruptive stage (Fodor et al., 1975).

\section{RESULTS: SUIKO SEAMOUNT, SITE 433}

The upper three flows recovered at Suiko Seamount are alkalic basalts. Hole 433A penetrated 11 meters of basalt; only Flow Unit 1 was recovered. Hole 433B yielded about 3 meters of Flow Unit 1 and eight large pieces and several smaller chips of Flow Unit 2. Hole 433C yielded about 2 meters of Flow Unit 1, overlying an interval of at least 4 meters of reef carbonate sand rich in volcanic material, which in turn overlies about 10 or 11 meters of Flow Unit 2, and a single 6-cm piece that is from Flow Unit 3. The total drilled interval below the top of Flow Unit 1 and before recovery of tholeiitic basalts of Flow Unit 4 is 41.5 meters (163.0 to 204.5 subbottom depth). From, and including, Flow Unit 4 downward, all the flows are tholeiitic basalts (less than 5 model $\%$ of any phenocryst phase), olivine tholeiites (more than 5 modal $\%$ olivine phenocrysts), tholeiitic picrites (more than 15 modal \% olivine phenocrysts), and plagioclase tholeiites (more than 5 modal $\%$ plagioclase phenocrysts). The terms plagioclase tholeiite and olivine tholeiite do not imply paragenetic sequence as proposed for abyssal tholeiites by Miyashiro et al., (1970). Instead, those terms are used here only to designate the abundance of phenocrysts present. The shipboard descriptions and analyses suggested that some of these flows are alkalic to transitional basalts, but we now believe that all these flows are tholeiitic (see Kirkpatrick et al., this volume). Part of the evidence for this conclusion is derived from the compositions of the groundmass pyroxene and plagioclase in these samples; pertinent data are presented in what follows.

We have analyzed a few to all the primary igneous phases in 29 samples from 26 flows. Because of the large number of samples, we shall describe each sample briefly and summarize the results for each major rock type. The figures $(3,4,5,6,7,8)$ show variation in mineral composition. Representative analyses of plagioclase, olivine, ilmenite and magnetite, pyroxene, and chrome spinel are given in Tables 2, 3, 4, 8, 9, respectively. The compositional data and equilibration temperatures are summarized in Table 11.

\section{Sample 433A-21-1, 30-36 cm: Alkalic Basalt}

This sample, from near the top of Flow Unit 1, has intergranular texture containing 2-mm phenocrysts of plagioclase $\left(\mathrm{An}_{80} \mathrm{Or}_{0}-\mathrm{An}_{58} \mathrm{Or}_{2}\right)$ that often have oscillatory zoning, 0.5 -mm microphenocrysts of clinopyroxene, and olivine that is now completely altered to clays, in a groundmass of plagioclase laths and $50 \mu \mathrm{m}$ equant grains $\left(\mathrm{An}_{59} \mathrm{Or}_{1}-\mathrm{An}_{56} \mathrm{Or}_{2}\right)$ and equant titanomagnetite $\left(\mathrm{Mt}_{41}-\mathrm{Mt}_{26}\right)$ grains with ilmenite exsolution. The clinopyroxene microphenocrysts have sector zoning similar to that described by Leung (1974) and Wass (1973). The colorless sectors have compositions in the range $\mathrm{Wo}_{38} \mathrm{En}_{46} \mathrm{Fs}_{16}$ to $\mathrm{Wo}_{40} \mathrm{En}_{42} \mathrm{Fs}_{18}$, and the pale brown sectors have compositions in the range $\mathrm{Wo}_{43}$ $\mathrm{En}_{44} \mathrm{Fs}_{13}$ to $\mathrm{Wo}_{45} \mathrm{En}_{38} \mathrm{Fs}_{18}$. In addition, the colored sec- 

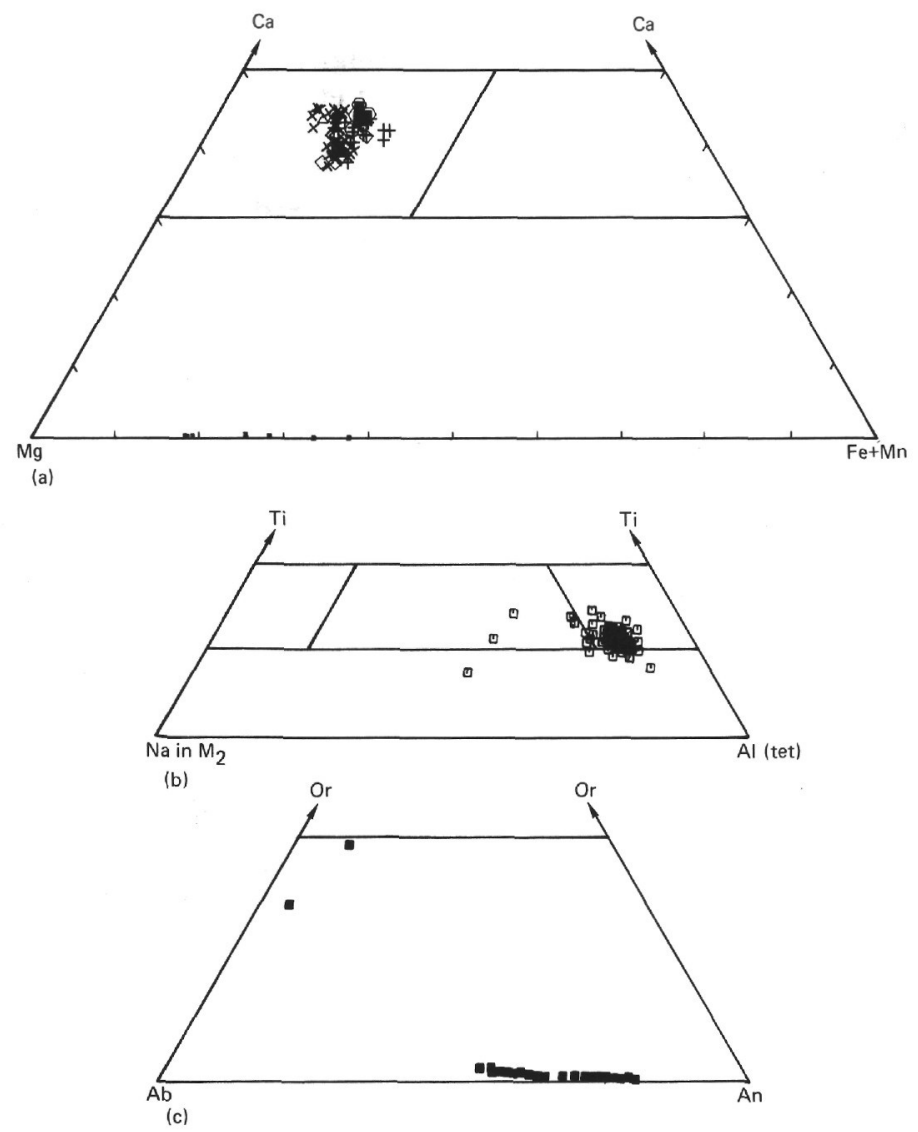
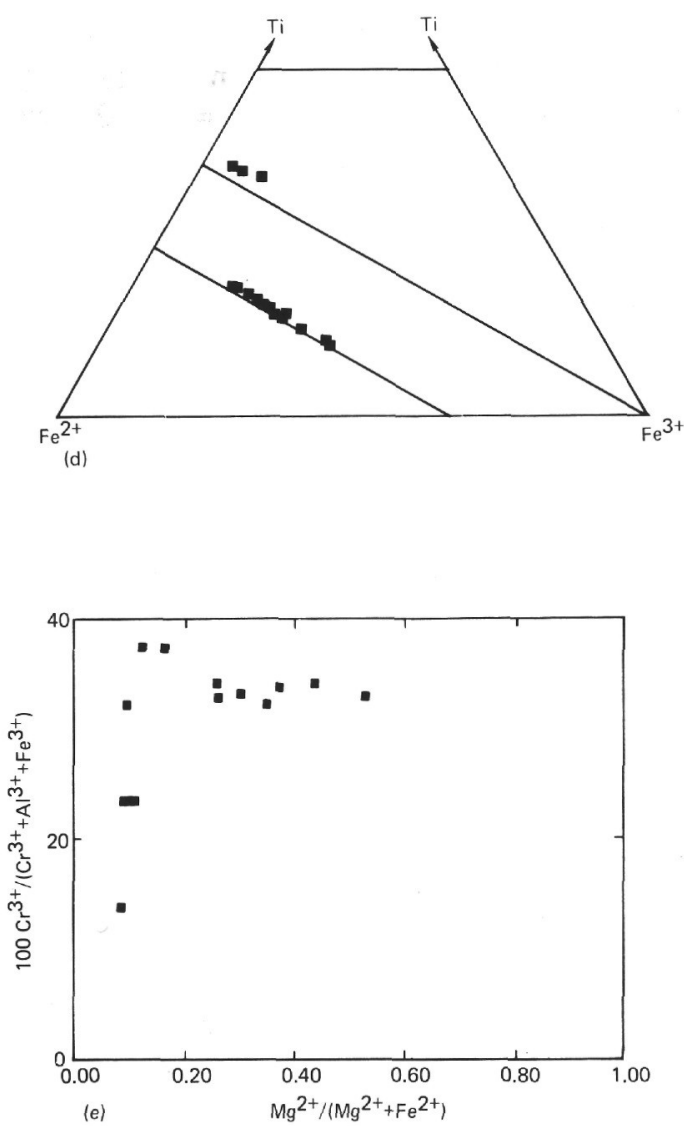

Figure 3. Mineralogy of the alkalic basalts from Holes 433A, 433B, and 433C. (a) Quadrilateral components of sector-zoned clinopyroxene: Forsterite content of olivine in Sample 433C-4-1, 30-38 cm plotted along the Fs-En join. Pyroxene symbols are groundmass $(+)$, colorless phenocryst core $(\times)$, pale brown phenocryst core $(\triangle)$, colorless phenocryst rim $(\diamond)$, and pale brown phenocryst rim $(\bigcirc)$. (b) "Other" components of clinopyroxene phenocrysts and groundmass. (c) Anothite, albite, and orthoclase components of felspar phenocrysts and groundmass. (d) $\mathrm{Ti}^{4+}, \mathrm{Fe}^{2+}, \mathrm{Fe}^{3+}$ cations of ilmenite and magnetite opaque oxides in the groundmass. (e) $\mathrm{Cr}^{3+} /\left(\mathrm{Cr}^{3+}+\mathrm{Al}^{3+}+\mathrm{Fe}^{3+}\right)$ versus $\mathrm{Mg}^{2+} /\left(\mathrm{Mg}^{2+}+\right.$ $\mathrm{Fe}^{2+}$ ) of chrome spinel in olivine, alkalic basalts from Holes 433A, 433B, and 433C. Some grains are in contact with the groundmass assemblage and have lower $\mathrm{AI}^{3+}, \mathrm{Cr}^{3+}$ and $\mathrm{Mg}^{2+}$ and higher $\mathrm{Fe}^{3+}, \mathrm{Fe}^{2+}$ and $\mathrm{Ti}^{4+}$.

ors contain more $\mathrm{TiO}_{2}, \mathrm{Al}_{2} \mathrm{O}_{3}, \mathrm{Na}_{2} \mathrm{O}$, and $\mathrm{Cr}_{2} \mathrm{O}_{3}$ than the colorless sectors. Figure 4 shows one such sectorzoned clinopyroxene crystal, and Table 10 lists 12 analyses from this crystal that are keyed to Figure 4. The rims of the colorless sectors are nearly identical to the cores; both contain 9 to 13 per cent total "other" components. The colored sectors have rims within the compositional range of the cores. The colored cores contain 18 to 25 mole per cent total "other" components, and the rims contain 21 to 27 per cent. The colored rims have $\mathrm{Al}_{2} \mathrm{O}_{3}$ contents as high as 6.7 per cent and $\mathrm{TiO}_{2}$ contents as high as 2.9 per cent. These distinctive clinopyroxene crystals are the basis for correlating Flow Unit 1 in the three holes that reached basement on Suiko Seamount.

\section{Sample 433A-21-4, 129-138 cm: Alkalic Basalt}

This sample, from near the bottom of Flow Unit 1, is nearly identical to Sample 433A-20-1, 30-36 cm. The sample has intergranular texture consisting of oscillating zoned plagioclase phenocrysts $\left(\mathrm{An}_{77-58} \mathrm{Or}_{1-2}\right)$, sector-zoned clinopyroxene identical to that in Sample 433A-20-1, 20-36 cm, and relict olivine (altered to clay minerals). The groundmass phases include feldspar $\left(\mathrm{An}_{61} \mathrm{Or}_{1}\right.$ to $\left.\mathrm{An}_{5} \mathrm{Or}_{35}\right)$, small equant exsolved titanomagnetite $\left(\mathrm{Mt}_{57}-\mathrm{Mt}_{22}\right)$, ilmenite $\left(\mathrm{Il}_{89}\right)$, and rare pyrite. The ilmenite is equant, whereas it is elongate in nearly all the other samples.

\section{Sample 433B-5-2, 61-68 cm: Alkalic Basalt}

This sample, from the base of Flow Unit 1, is nearly identical to samples 433A-20-1, 30-36 cm and 433A-21$4,129-138 \mathrm{~cm}$. The sample has intergranular texture, but unlike the other samples from Flow Unit 1, its feldspar laths are strongly aligned. It contains $2-\mathrm{mm}$ plagioclase phenocrysts $\left(\mathrm{An}_{81-68} \mathrm{Or}_{0-1}\right)$ with oscillatory zoning; 1-mm clinopyroxene phenocrysts with both concentric $\left(\mathrm{Wo}_{44} \mathrm{En}_{40} \mathrm{Fs}_{16}-\mathrm{Wo}_{41} \mathrm{En}_{40} \mathrm{Fs}_{19}\right)$ and sector (pale brown 

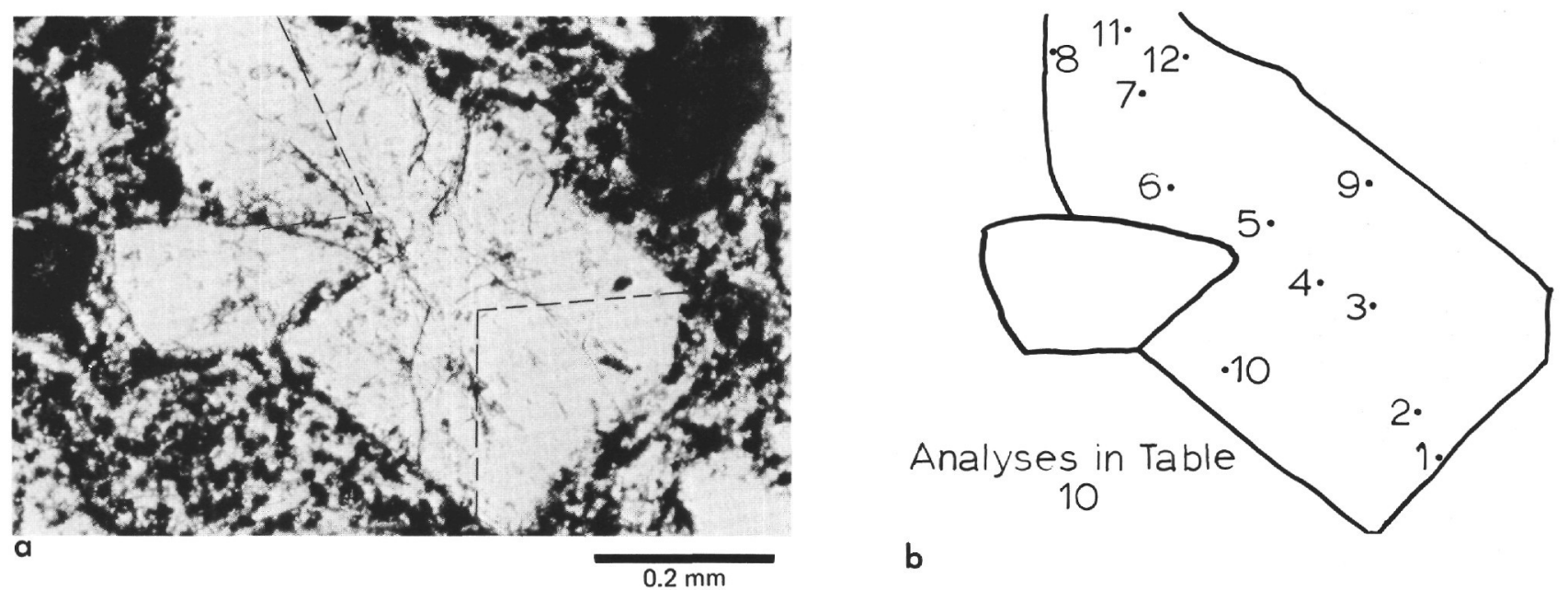

b
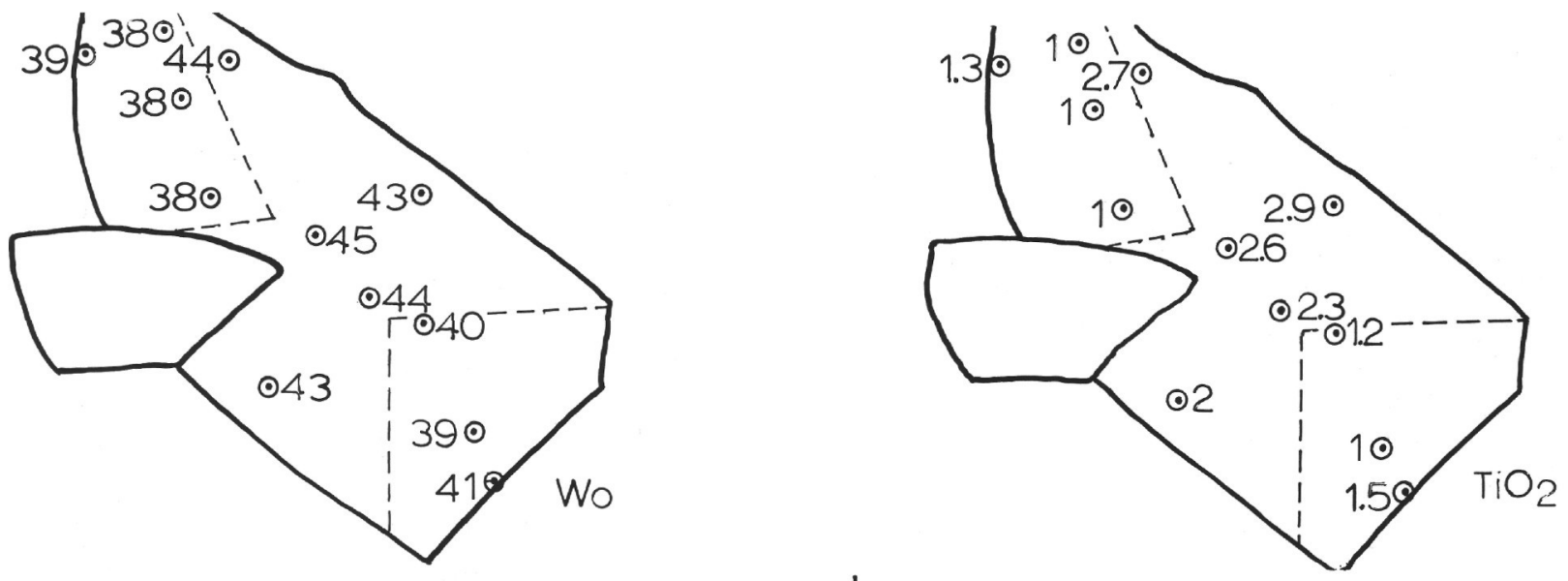

c

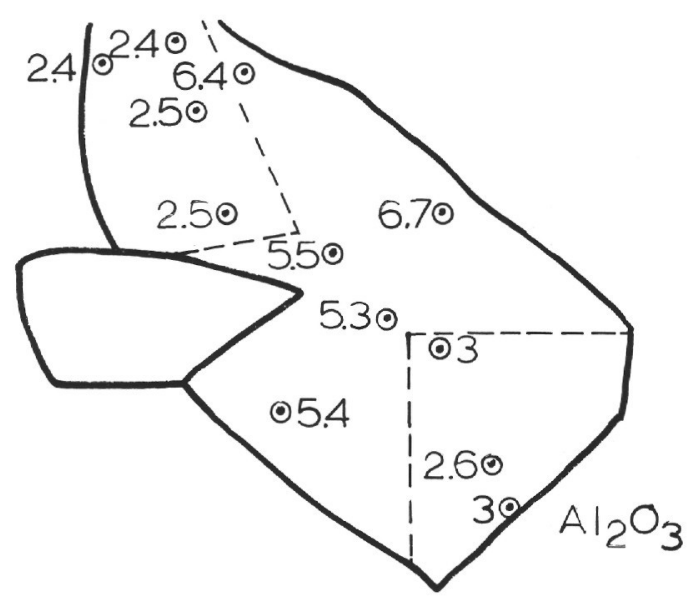

d

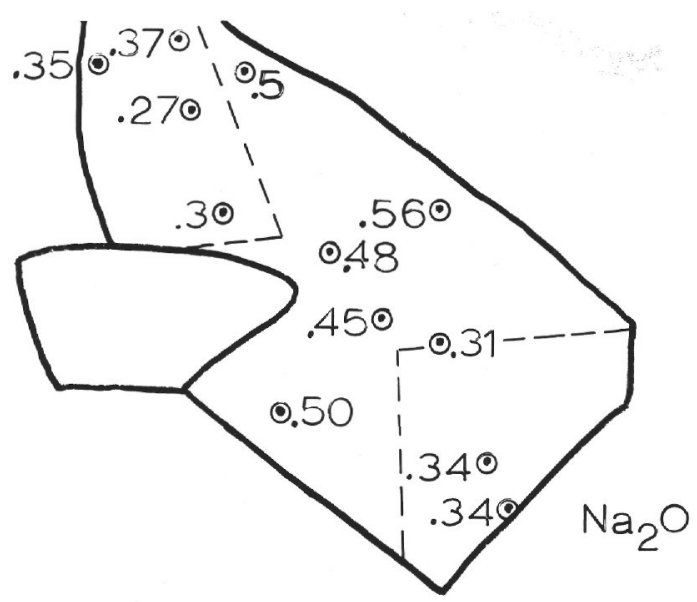

e

\section{f}

Figure 4. Photomicrograph (a) of sector-zoned clinopyroxene in alkalic basalt Sample 433A-20-1, 30-36 cm. Numbers in (b) are keyed to analyses in Table 10. The other sketches show the distribution of per cent Wo (c), TiO ${ }_{2}(d)$, $\mathrm{Al}_{2} \mathrm{O}_{3}(e)$, and $\mathrm{Na}_{2} \mathrm{O}(f)$.

sectors are $\mathrm{Wo}_{44} \mathrm{En}_{40} \mathrm{Fs}_{16}$ to $\mathrm{Wo}_{45} \mathrm{En}_{38} \mathrm{Fs}_{17}$ and colorless sectors are $\mathrm{Wo}_{40} \mathrm{En}_{44} \mathrm{Fs}_{16}$ to $\mathrm{Wo}_{41} \mathrm{En}_{40} \mathrm{Fs}_{19}$ ) zoning, and relict olivine now altered to clay minerals. The altered olivine phenocrysts are more abundant than in the previous samples. The groundmass consists of feldspar $\left(\mathrm{An}_{59} \mathrm{Or}_{1}-\mathrm{An}_{53} \mathrm{Or}_{2}\right)$, clinopyroxene $\left(\mathrm{Wo}_{44} \mathrm{En}_{37} \mathrm{Fs}_{19^{-}}\right.$ $\mathrm{Wo}_{41} \mathrm{En}_{40} \mathrm{Fs}_{19}$ ) in two compositional groups correspond- ing to the colored and colorless sectors of sector-zoned phenocrysts, equant titanomagnetite $\left(\mathrm{Mt}_{41}-\mathrm{Mt}_{21}\right)$ and ilmenite ( $\mathrm{Il}_{93-95}$ ), and rare pyrite and calcopyrite. One plagioclase phenocryst ( core $=\mathrm{An}_{80}$, $\mathrm{rim}=\mathrm{An}_{61}$ ) contains a single $20 \mu \mathrm{m}$ feldspar grain $\left(\mathrm{An}_{55} \mathrm{Or}_{2}-\mathrm{An}_{10} \mathrm{Or}_{48}\right)$ in its core. Some titanomagnetite grains contain visible ilmenite exsolution lamellae. 

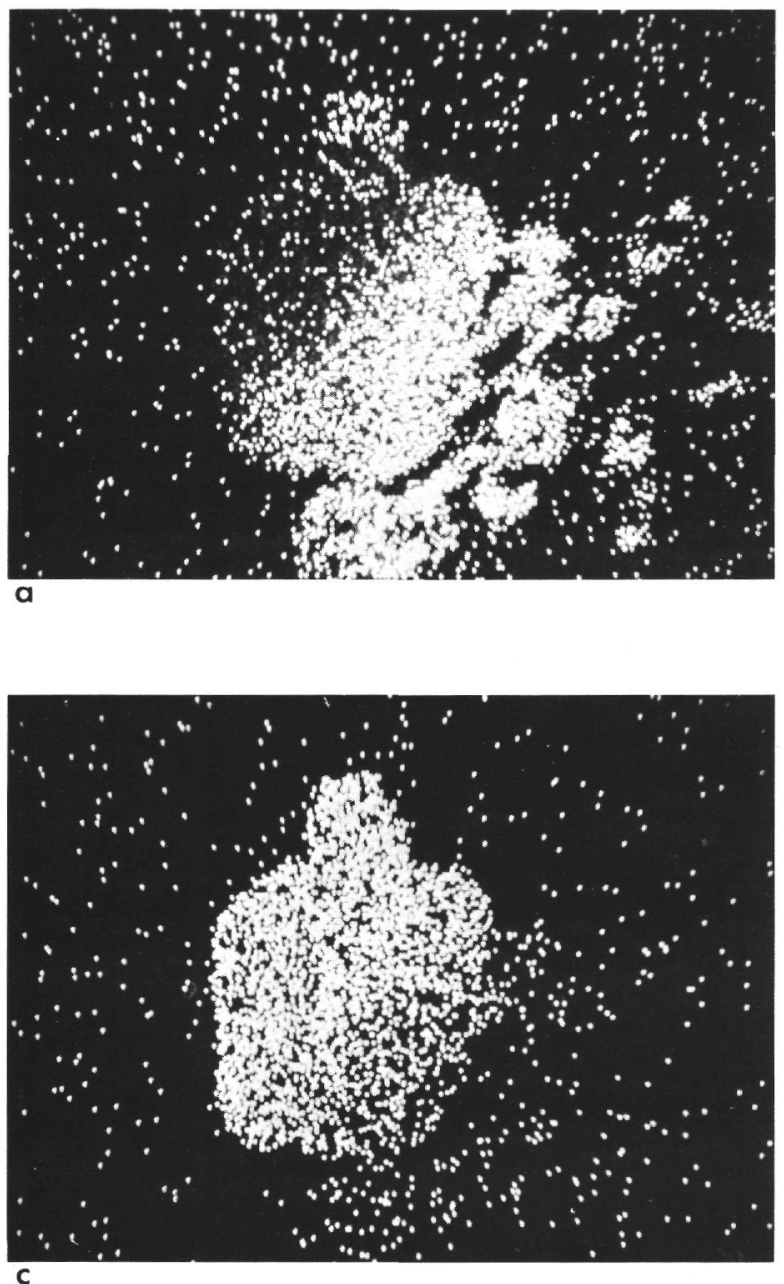

C

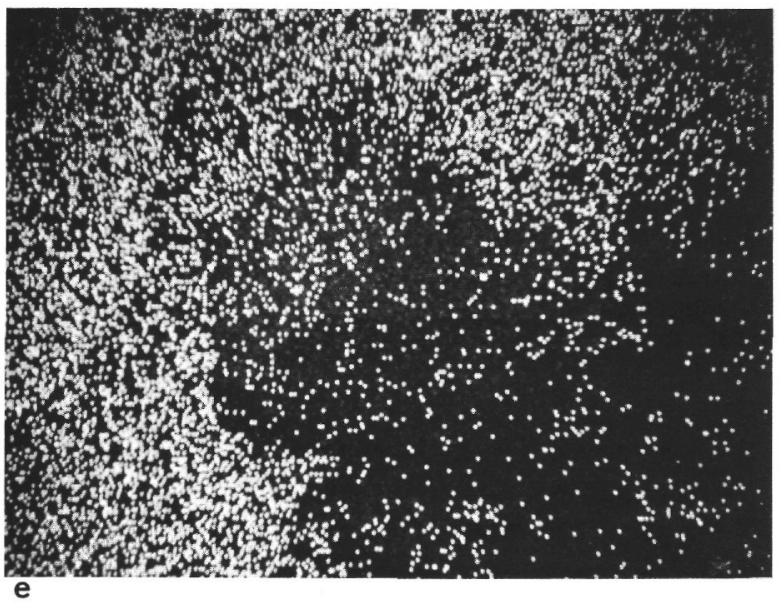

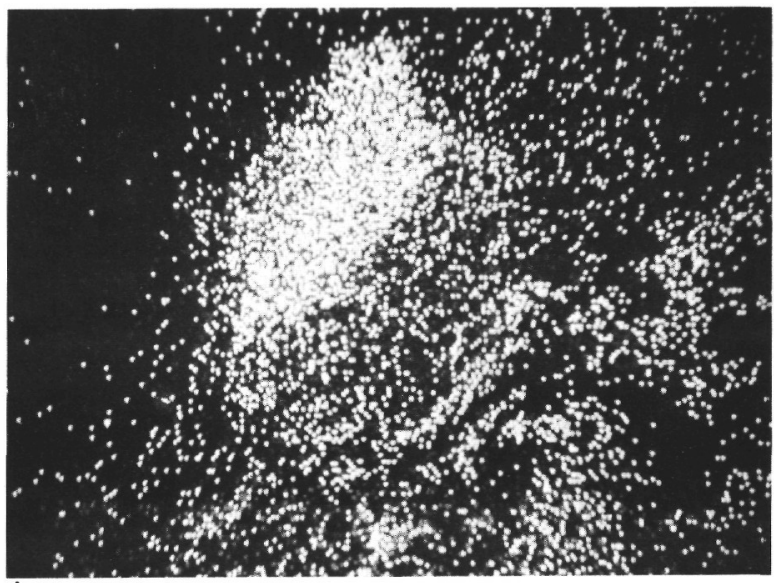

b

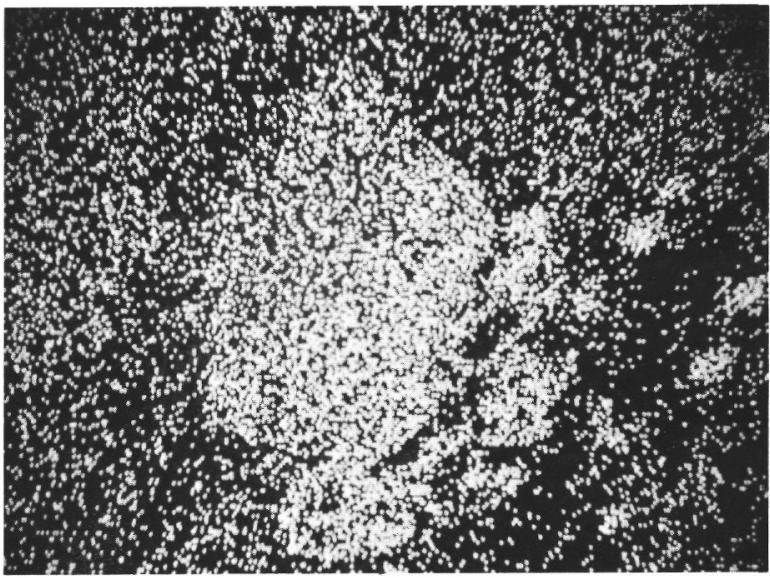
d

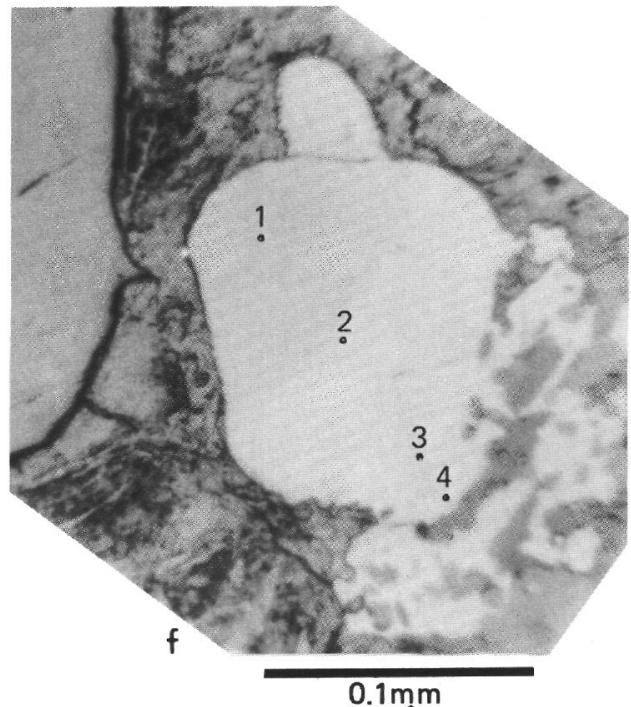

Figure 5. Chromian spinel that has partly reacted with the adjacent groundmass in Sample 433C-4-1, 30-38 cm. Secondary X-ray scans are shown for $\mathrm{Ti}(\mathrm{a}), \mathrm{Al}(\mathrm{b}), \mathrm{Cr}(\mathrm{c}), \mathrm{Fe}(\mathrm{d})$, and $\mathrm{Mg}(\mathrm{e})$. The reflecting-light photomicrograph $(f)$ shows the sharp boundary between aluminous chromian spinel and a titaniferous chromite that results from reaction of the aluminous chromian spinel and the groundmass. The aluminous chromian spinel is enclosed in olivine and saponite that is secondary after olivine; the titaniferous chromite is in contact with the groundmass. The numbers in (f) correspond to analyses 3, 5, 7, and 8 given in Table 9. 

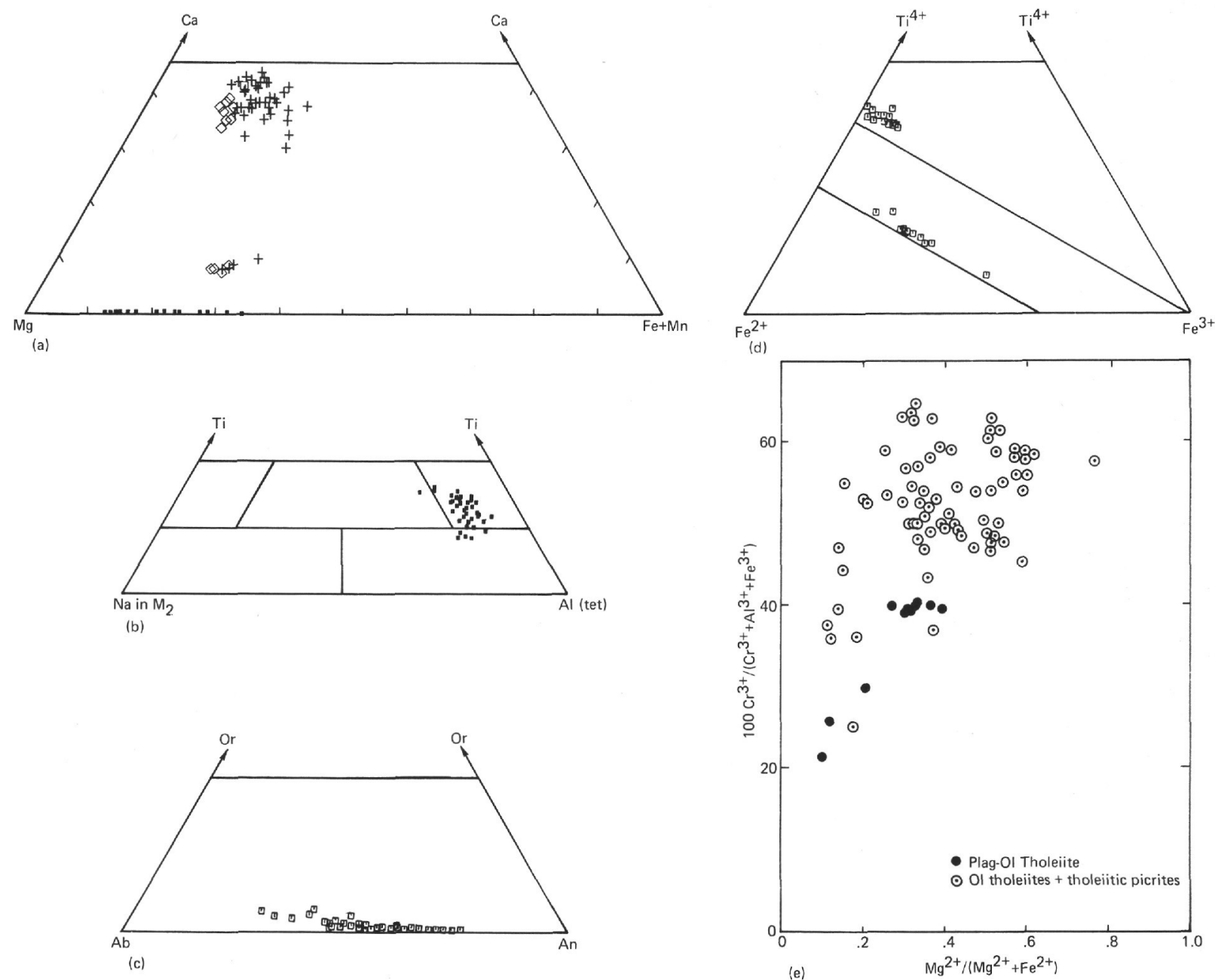

Figure 6. Mineralogy of olivine tholeites (modal olivine $>5 \%$ ) and picrites (modal olivine $>15 \%$ ) from Hole 433C. (a) Quadrilateral components of clinopyroxene phenocrysts and groundmass, and pigeonite groundmass. Olivine forsterite content is plotted along the enstatite-ferrosilite join. Pyroxene symbols as in Figure 1a. (b) "Other" components of pyroxene phenocrysts and groundmass. (c) Ternary diagram of the anorthite, albite, and orthoclase components of feldspar in the olivine tholeites and picrites. (d) $\mathrm{Ti}^{4+}, \mathrm{Fe}^{2+}$, and $\mathrm{Fe}^{3+}$ in opaque oxides. (e) Variation diagram of $\mathrm{Cr}^{3+} /\left(\mathrm{Cr}^{3+}+\mathrm{Al}^{3+}+\mathrm{Fe}^{3+}\right)$ versus $\mathrm{Mg}^{2+} /\left(\mathrm{Mg}^{2+}+\mathrm{Fe}^{2+}\right)$ in chromian spinel.

\section{Sample 433B-5-3, 85-90 cm: Alkalic Basalt}

This sample, from near the top of Flow Unit 2, has a pilotaxitic texture with oscillatory zoned, $1-\mathrm{mm}$ plagioclase $\left(\mathrm{An}_{79} \mathrm{Or}_{0}-\mathrm{An}_{63} \mathrm{Or}_{1}\right)$ phenocrysts; 2 -mm rounded clinopyroxene $\left(\mathrm{Wo}_{44} \mathrm{En}_{42} \mathrm{Fs}_{14}\right)$ phenocrysts with occasional plagioclase inclusions $\left(\mathrm{An}_{77} \mathrm{Or}_{0}\right)$; clusters of 1-mm clinopyroxene with compositions falling into two discrete groups $\left(\mathrm{Wo}_{41} \mathrm{En}_{44} \mathrm{Fs}_{15}\right.$ to $\mathrm{Wo}_{40} \mathrm{En}_{44} \mathrm{Fs}_{16}$ and $\mathrm{Wo}_{44} \mathrm{En}_{42} \mathrm{Fs}_{14}$ to $\mathrm{Wo}_{43} \mathrm{En}_{39} \mathrm{Fs}_{18}$ ); and olivine phenocrysts and kink-banded xenocrysts (not analyzed) partially altered to clays. The groundmass consists of plagioclase (not analyzed); clinopyroxene that also has two discrete compositional groups within the range $\mathrm{Wo}_{44} \mathrm{En}_{39} \mathrm{Fs}_{17}$ $\mathrm{Wo}_{38} \mathrm{En}_{44} \mathrm{Fs}_{18}$; and titanomagnetite $\left(\mathrm{Mt}_{39}-\mathrm{Mt}_{25}\right)$. Olivine phenocrysts contain rare euhedral chromian spinel to picotite grains $\left\{\left(\mathrm{Cr}_{4.5-5.1} \mathrm{Al}_{6.3-6.9} \mathrm{Fe}_{3-3.3}^{3+}\right)\left(\mathrm{Mg}_{3.1-4.4} \mathrm{Mn}_{0.1}\right.\right.$ $\left.\left.\mathrm{Fe}_{2.9-4.4}^{2+}\right)\left(\mathrm{Ti}_{0.5-0.9} \mathrm{Fe}_{1.0-1.8}^{2+}\right) \mathrm{O}_{32}\right\}$.

\section{Sample 433C-4-1, 30-38 cm: Alkalic Basalt}

This sample, from near the top of Flow Unit 2, has a pilotaxitic to intergranular texture, and contains olivine $\left(\mathrm{Fo}_{82}-\mathrm{Fo}_{63}\right)$ phenocrysts and kink-banded xenocrysts, plagioclase $\left(\mathrm{An}_{78} \mathrm{Or}_{1}\right)$, and clinopyroxene $\left(\mathrm{Wo}_{44} \mathrm{En}_{45} \mathrm{Fs}_{11}\right.$ to $\mathrm{Wo}_{44} \mathrm{En}_{42} \mathrm{Fs}_{13}$; "others" = 11-19 mole \%); and rare euhedral to rounded spinel in olivine. The groundmass consists of clinopyroxene $\left(\mathrm{Wo}_{41} \mathrm{En}_{42} \mathrm{Fs}_{17}-\mathrm{Wo}_{41} \mathrm{En}_{38} \mathrm{Fs}_{21}\right.$; "others" = 6-22 mole \%); feldspar (not analyzed), and both titanomagnetite $\left(\mathrm{Mt}_{32-28}\right)$ and ilmenite $\left(\mathrm{Il}_{92}\right)$; and rare pyrite and calcopyrite. The groundmass pyroxene generally has lower $\mathrm{Al}_{2} \mathrm{O}_{3}$ and Wo contents than the phenocrysts. The rims on the clinopyroxene phenocrysts have the same composition as the groundmass clinopyroxene. The chromian spinel is zoned to chromian titanomagnetite where chrome spinel is in contact with the groundmass. In Figure 5, Fe, Mg, $\mathrm{Ti}, \mathrm{Al}$, and $\mathrm{Cr}$ scans 

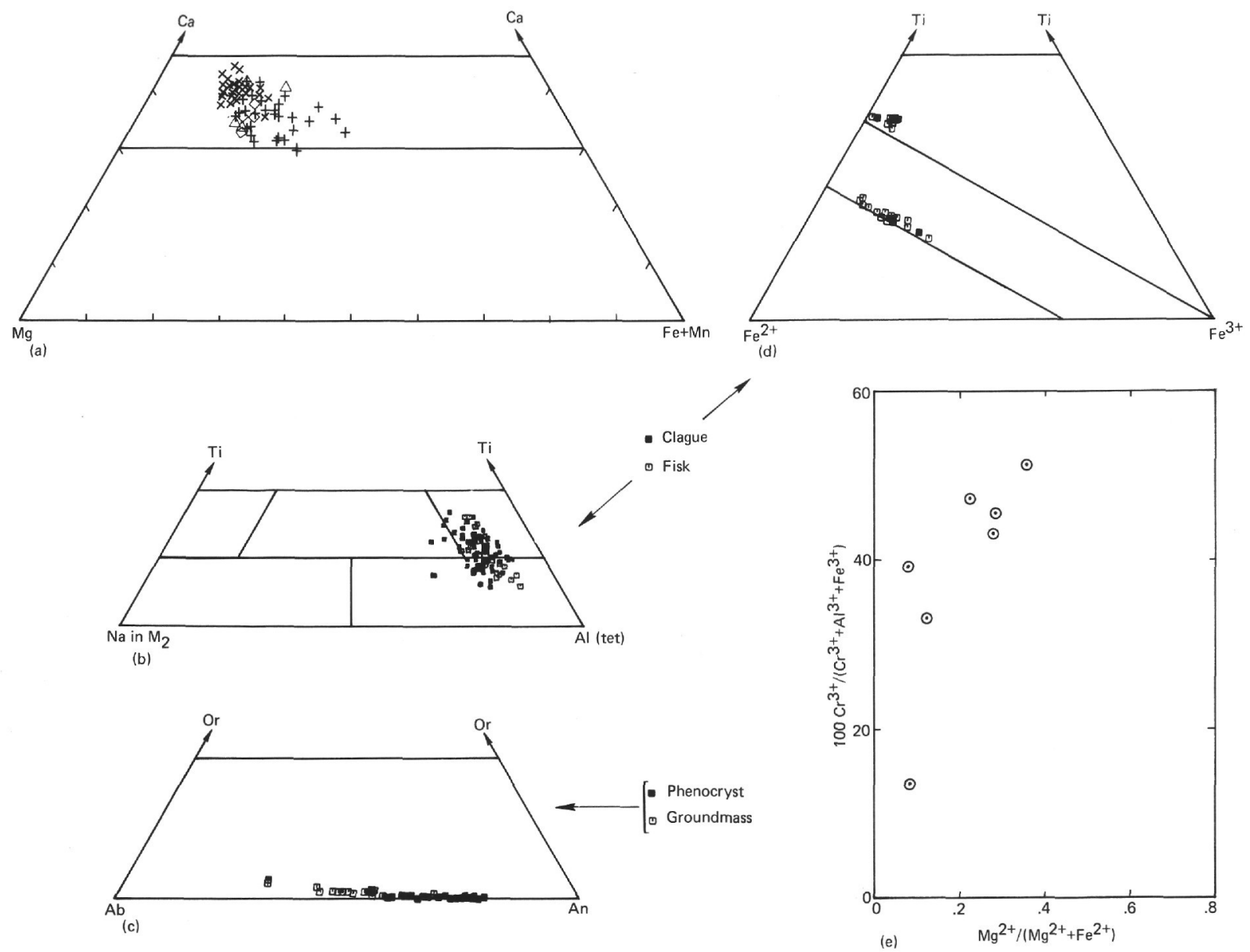

Figure 7. Mineralogy of plagioclase tholeiites (modal plagioclase $>5 \%$ ) from Hole 433C. (a) Quadrilateral components of clinopyroxene phenocrysts and groundmass. All the olivine in these samples is completely altered. Pyroxene symbols as in Figure 1a. (b) "Other" components of clinopyroxene phenocrysts and groundmass. (c) Ternary diagram of feldspar components in plagioclase phenocrysts and groundmass. (d) Ilmenite and magnetite opaque oxides plotted in a ternary diagram of $\mathrm{Ti}^{4+}, \mathrm{Fe}^{2+}$, and $\mathrm{Fe}^{3+}$. (e) Variation diagram of $\mathrm{Cr}^{3+}\left(\mathrm{Cr}^{3+}+\mathrm{Al}^{3+}+\mathrm{Fe}^{3+}\right)$ versus $\mathrm{Mg}^{2+} /\left(\mathrm{Mg}^{2+}+\right.$ $\mathrm{Fe}^{2+}$ ) in chromian spinel.

of one of these zoned grains and a photomicrograph of the same grain in reflected light show that the boundary seen in reflected light is not a major discontinuity for $\mathrm{Cr}$, but rather for $\mathrm{Mg}, \mathrm{Al}$, and $\mathrm{Ti}$, and marks the boundary between a chromian spinel within the olivine crystal and a chromian titanomagnetite in contact with the groundmass. Representative analyses of several spots on the crystal shown are given in Table 9 and keyed to the photograph in Figure 5. Similar zoned chrome spinel grains are described by Haggerty (1976).

\section{Site 433 Alkalic Basalts: Summary and Interpretation}

The mineralogy of alkalic basalt Flow Units 1 and 2 is summarized in Table 11. The analyses of plagioclase, clinopyroxene, and olivine, $\mathrm{Fe}-\mathrm{Ti}$ oxides, and chrome spinel are shown in Figure 3.

Flow Unit 1 (Samples 433A-20-1, 30-36 cm; 433A21-4, 129-138 cm; and 433B-5-2, 61-68 cm) contains oscillating zoned phenocrysts of plagioclase $\left(\mathrm{An}_{81-68}\right.$ $\mathrm{Or}_{0-1}$ ) (cores are commonly $\mathrm{An}_{81}-\mathrm{An}_{70}$ and rims $\mathrm{An}_{70^{-}}$
$A n_{55}$ ), clinopyroxene with distinctive sector zoning (pale brown sectors have $\mathrm{Wo}_{43} \mathrm{En}_{44} \mathrm{Fs}_{13}$ to $\mathrm{Wo}_{45} \mathrm{En}_{38} \mathrm{Fs}_{17}$ and colorless sectors have $\mathrm{Wo}_{38} \mathrm{En}_{46} \mathrm{Fs}_{16}$ to $\mathrm{Wo}_{41} \mathrm{En}_{40} \mathrm{Fs}_{19}$ ), and olivine completely altered to clays. The groundmass consists of feldspar $\left(\mathrm{An}_{61} \mathrm{Or}_{1}-\mathrm{An}_{5} \mathrm{Or}_{35}\right)$, ilmenite $\left(\mathrm{Il}_{89^{-}}\right.$ $\left.\mathrm{Il}_{95}\right)$, and titanomagnetite $\left(\mathrm{Mt}_{57}-\mathrm{Mt}_{21}\right)$ with common ilmenite exsolution lamallae. Pyrite and chalcopyrite are present, particularly near the bottom of the flow, but rare.

Flow Unit 2 (Samples 433B-5-3, 85-90 cm and 433C4-1, 30-38 cm) contains phenocrysts of plagioclase $\left(\mathrm{An}_{79-}\right.$ $\left.{ }_{63} \mathrm{Or}_{0-1}\right)$, clinopyroxene $\left(\mathrm{Wo}_{44} \mathrm{En}_{45} \mathrm{Fs}_{11}\right.$ to $\mathrm{Wo}_{43} \mathrm{En}_{39} \mathrm{Fs}_{18}$ and $\mathrm{Wo}_{41} \mathrm{En}_{44} \mathrm{Fs}_{15}$ to $\left.\mathrm{Wo}_{40} \mathrm{En}_{44} \mathrm{Fs}_{16}\right)$ and olivine cores $\left(\mathrm{Fo}_{82-81}\right)$ with rims as iron-rich as $\mathrm{Fo}_{63}$. Some of the olivine crystals are xenocrysts with kink bands. Many of the olivine phenocrysts contain small euhedral to rounded chromian spinel to picotite crystals that are zoned to chromian titanomagnetite where in contact with the groundmass. The groundmass clinopyroxene ranges from $\mathrm{Wo}_{44} \mathrm{En}_{39} \mathrm{Fs}_{17}$ to $\mathrm{Wo}_{41} \mathrm{En}_{38} \mathrm{Fs}_{21}$. Both titanomag- 

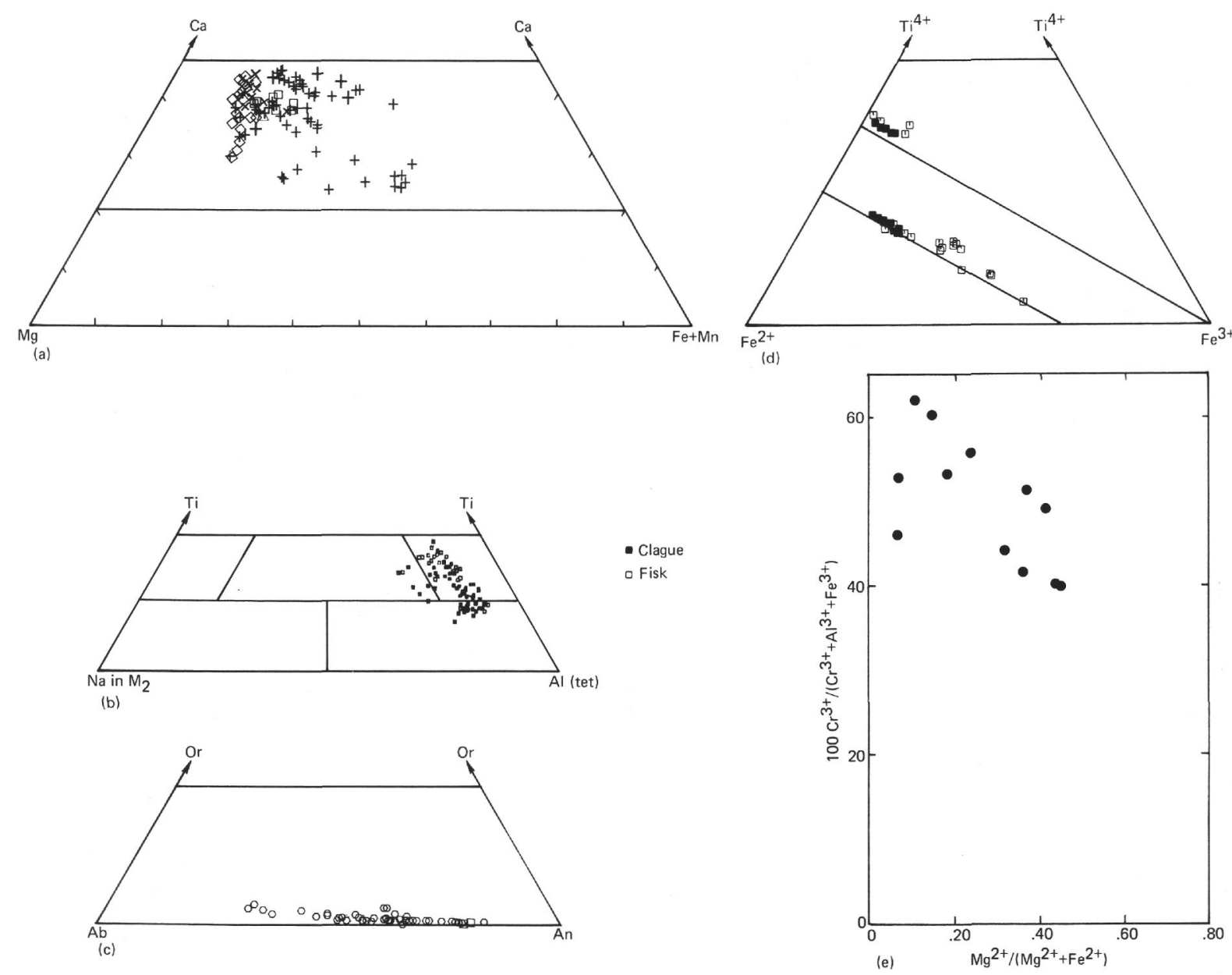

Figure 8. Mineralogy of Hole 433 C tholeiites (no phenocryst phase $>5$ modal \%). (a) Quadrilateral components of groundmass and phenocryst clinopyroxene. All olivine in these samples has been completely altered. Pyroxene symbols as in Figure 1a. (b) "Other" components of groundmass and phenocryst clinopyroxene. (c) Feldspar components of plagioclase phenocrysts and groundmass. (d) Ilmenite and magnetite opaque oxides, plotted on a $\mathrm{Ti}^{4+}, \mathrm{Fe}^{2+}, \mathrm{Fe}^{3+}$ ternary diagram. (e) Chrome spinel variation diagram of $\mathrm{Cr}^{3+} /\left(\mathrm{Cr}^{3+}+\mathrm{Al}^{3+} \mathrm{Fe}^{3+}\right)$ versus $\mathrm{Mg}^{2+} /\left(\mathrm{Mg}^{2+}+\mathrm{Fe}^{2+}\right)$.

netite $\left(\mathrm{Mt}_{39-25}\right.$, with most between $\mathrm{Mt}_{29}$ and $\left.\mathrm{Mt}_{25}\right)$ and ilmenite $\left(\mathrm{Il}_{93}\right)$ are present. Pyrite and chalcopyrite are present but rare.

The calculated temperature of plagioclase phenocryst $\left(\mathrm{An}_{80-68}\right)$ crystallization in Flow 1 is $1440^{\circ} \mathrm{C}$ to $1250^{\circ} \mathrm{C}$, assuming that these phenocrysts crystallized from a magma of the same composition as the present whole rock. These unreasonably high temperatures indicate that the plagioclase phenocrysts are not cognate. The temperature of crystallization of the olivine (now altered to clay) is not known.

In Flow 2, we estimate the equilibrium olivine composition to be $\mathrm{Fo}_{79}$ (based on a $\mathrm{K}_{\mathrm{D}}=0.3$, from Roeder and Emslie, 1970, and $\mathrm{Fe}^{3+} /\left(\mathrm{Fe}^{3+}+\mathrm{Fe}^{2+}\right)=0.1$, and assuming that the olivine crystallized from a magma of the same composition as the whole rock (Kirkpatrick et al., this volume). This olivine $\left(\mathrm{Fo}_{79}\right)$ would have crystallized at $1168^{\circ} \mathrm{C}$, if we use the geothermometer of Fisk et al. (1978). The Fisk geothermometer was calibrated on oceanic and Iceland basalts, and agrees closely with the geothermometer of Bender et al. (1978). The plagioclase in equilibrium with the whole-rock composition at this temperature is $\mathrm{An}_{67}$, so plagioclase phenocrysts rims $\left(\mathrm{An}_{60-65}\right)$ could have crystallized at the same time as the olivine cores. The plagioclase cores $\left(\mathrm{An}_{75-81}\right)$ and clinopyroxene crystallized before olivine, since some are enclosed in olivine. Application of the Evans and Frost (1975) olivine-spinel geothermometer indicates crystallization of the olivine-spinel pairs at temperatures near $1000^{\circ} \mathrm{C}$, and suggests that the spinel has been altered. The coexisting ilmenite-titanomagnetite pair indicates equilibrium at $1020^{\circ} \mathrm{C}$ to $990^{\circ} \mathrm{C}$ under an oxygen fugacity of $10^{-11}$ atmospheres (Buddington and Lindsley, 1964). Texturally, the Fe-Ti oxides were the last minerals to crystallize, indicating that the groundmass crystallized between $1150^{\circ} \mathrm{C}$ and $990^{\circ} \mathrm{C}$. These temperatures are similar to those reported by Peck (1978) for crystallization of the Alae lava lake at Kilauea, where the maximum temperatures were $1140^{\circ} \mathrm{C}$ and the solidus was at $980^{\circ} \mathrm{C}$.

The groundmass pyroxene and plagioclase compositions in Flow Units 1 and 2 are similar to those found in 
TABLE 8

Representative Pyroxene Analyses from Site 433 (Oxides wt. \%)

\begin{tabular}{|c|c|c|c|c|c|c|c|c|c|c|c|}
\hline & 1 & 2 & 3 & 4 & 5 & 6 & 7 & 8 & 9 & 10 & 11 \\
\hline $\mathrm{SiO}_{2}$ & 50.90 & 47.73 & 50.70 & 49.78 & 46.76 & 50.05 & 49.21 & 51.34 & 51.91 & 48.57 & 50.22 \\
\hline $\mathrm{TiO}_{2}$ & 1.22 & 2.36 & 1.13 & 1.34 & 2.51 & 1.52 & 1.58 & 0.64 & 0.60 & 1.49 & 0.85 \\
\hline $\mathrm{Al}_{2} \mathrm{O}_{3}$ & 2.49 & 5.04 & 2.71 & 4.31 & 5.50 & 2.59 & 4.66 & 2.30 & 2.30 & 4.88 & 1.48 \\
\hline $\mathrm{FeO}$ & 10.18 & 10.61 & 10.30 & 7.25 & 10.09 & 10.64 & 7.40 & 9.73 & 6.91 & 6.24 & 17.98 \\
\hline $\mathrm{MnO}$ & 0.27 & 0.18 & 0.27 & 0.13 & 0.18 & 0.24 & 0.18 & 0.22 & 0.20 & 0.14 & 0.47 \\
\hline $\mathrm{MgO}$ & 15.64 & 12.82 & 15.31 & 14.53 & 13.11 & 13.81 & 15.46 & 19.71 & 17.87 & 15.40 & 11.89 \\
\hline $\mathrm{CaO}$ & 18.96 & 20.75 & 19.55 & 21.79 & 20.96 & 20.30 & 20.54 & 14.83 & 19.06 & 20.75 & 16.59 \\
\hline $\mathrm{Na}_{2} \mathrm{O}$ & 0.38 & 0.56 & 0.33 & 0.34 & 0.49 & 0.49 & 0.30 & 0.32 & 0.19 & 0.24 & 0.29 \\
\hline $\mathrm{Cr}_{2} \mathrm{O}_{3}$ & 0.05 & 0.02 & 0.04 & 0.67 & 0.24 & 0.00 & 0.62 & 0.16 & 0.57 & 1.24 & 0.00 \\
\hline TOTAL & 100.09 & 100.07 & 100.34 & 100.14 & 99.84 & 99.64 & 99.95 & 99.25 & 99.61 & 98.95 & 99.77 \\
\hline \multicolumn{12}{|c|}{ Cations, Oxygen $=6$} \\
\hline $\mathrm{Si}$ & 1.888 & 1.786 & 1.879 & 1.840 & 1.752 & 1.880 & 1.817 & 1.891 & 1.907 & 1.809 & 1.931 \\
\hline $\mathrm{Al} I \mathrm{~V}$ & 0.109 & 0.214 & 0.118 & 0.160 & 0.243 & 0.115 & 0.183 & 0.100 & 0.093 & 0.191 & 0.067 \\
\hline $\mathrm{Al}{ }^{\mathrm{VI}}$ & 0.000 & 0.008 & 0.000 & 0.028 & 0.000 & 0.000 & 0.019 & 0.000 & 0.006 & 0.023 & 0.000 \\
\hline $\mathrm{Fe}^{2+}$ & 0.249 & 0.219 & 0.241 & 0.161 & 0.186 & 0.270 & 0.149 & 0.217 & 0.162 & 0.129 & 0.539 \\
\hline $\mathrm{Fe}^{3+}$ & 0.067 & 0.113 & 0.078 & 0.063 & 0.130 & 0.065 & 0.080 & 0.083 & 0.051 & 0.066 & 0.040 \\
\hline $\mathrm{Mg}$ & 0.865 & 0.715 & 0.845 & 0.800 & 0.732 & 0.775 & 0.851 & 1.802 & 0.978 & 0.855 & 0.681 \\
\hline $\mathrm{Mn}$ & 0.008 & 0.006 & 0.008 & 0.004 & 0.006 & 0.008 & 0.006 & 0.007 & 0.006 & 0.004 & 0.015 \\
\hline $\mathrm{Ti}$ & 0.034 & 0.066 & 0.031 & 0.037 & 0.071 & 0.043 & 0.044 & 0.018 & 0.017 & 0.042 & 0.025 \\
\hline $\mathrm{Cr}$ & 0.001 & 0.001 & 0.001 & 0.020 & 0.007 & 0.000 & 0.018 & 0.005 & 0.017 & 0.037 & 0.000 \\
\hline $\mathrm{Ca}$ & 0.754 & 0.832 & 0.776 & 0.863 & 0.842 & 0.817 & 0.812 & 0.585 & 0.750 & 0.828 & 0.683 \\
\hline $\mathrm{Na}$ & 0.027 & 0.041 & 0.024 & 0.024 & 0.036 & 0.036 & 0.021 & 0.023 & 0.014 & 0.017 & 0.022 \\
\hline \multicolumn{12}{|c|}{ Pyroxene Components, Mol \% } \\
\hline $\mathrm{Ca}$ & 40.5 & 44.3 & 40.0 & 45.7 & 44.5 & 42.5 & 42.9 & 29.8 & 38.6 & 44.1 & 35.2 \\
\hline $\mathrm{Mg}$ & 44.0 & 38.1 & 43.6 & 42.4 & 38.7 & 40.2 & 45.0 & 55.0 & 50.4 & 45.5 & 35.1 \\
\hline Fet & 15.5 & 17.7 & 16.4 & 11.9 & 16.7 & 17.4 & 12.1 & 15.2 & 10.9 & 10.4 & 29.8 \\
\hline Others & 10.9 & 21.4 & 11.8 & 16.0 & 24.3 & 11.5 & 18.3 & 10.5 & 9.3 & 19.1 & 6.7 \\
\hline
\end{tabular}

\begin{tabular}{|c|c|c|c|c|c|c|c|c|c|c|c|}
\hline & 24 & 25 & 26 & 27 & 28 & 29 & 30 & 31 & 32 & 33 & 34 \\
\hline $\mathrm{SiO}_{2}$ & 49.44 & 49.04 & 50.11 & 49.73 & 52.41 & 49.73 & 48.83 & 49.94 & 50.27 & 52.12 & 50.42 \\
\hline $\mathrm{TiO}_{2}$ & 1.43 & 2.11 & 1.44 & 1.66 & 0.58 & 1.21 & 1.26 & 1.69 & 1.53 & 0.48 & 1.23 \\
\hline $\mathrm{Al}_{2} \mathrm{O}_{3}$ & 4.32 & 3.36 & 3.64 & 2.36 & 1.95 & 1.73 & 1.39 & 3.46 & 2.41 & 2.71 & 2.45 \\
\hline $\mathrm{FeO}$ & 11.85 & 10.64 & 7.59 & 15.55 & 6.83 & 19.69 & 25.79 & 8.54 & 15.13 & 6.70 & 10.26 \\
\hline $\mathrm{MnO}$ & 0.32 & 0.25 & 0.19 & 0.41 & 0.14 & 0.35 & 0.56 & 0.21 & 0.41 & 0.21 & 0.23 \\
\hline $\mathrm{MgO}$ & 14.27 & 14.06 & 15.80 & 15.36 & 17.50 & 14.42 & 10.21 & 15.31 & 14.64 & 17.20 & 16.31 \\
\hline $\mathrm{CaO}$ & 16.54 & 19.81 & 19.94 & 14.42 & 19.34 & 10.92 & 11.63 & 19.50 & 15.35 & 19.65 & 17.64 \\
\hline $\mathrm{Na}_{2} \mathrm{O}$ & 0.47 & 0.40 & 0.37 & 0.21 & 0.25 & 0.18 & 0.17 & 0.29 & 0.30 & 0.29 & 0.21 \\
\hline $\mathrm{Cr}_{2} \mathrm{O}_{3}$ & 0.06 & 0.00 & 0.50 & 0.05 & 0.68 & 0.00 & 0.00 & 0.66 & 0.00 & 0.61 & 0.05 \\
\hline TOTAL & 98.70 & 99.67 & 99.58 & 99.75 & 99.68 & 98.23 & 99.84 & 99.60 & 100.04 & 99.97 & 98.80 \\
\hline \multicolumn{12}{|c|}{ Cations, Oxygen $=6$} \\
\hline $\mathrm{Si}$ & 1.870 & 1.843 & 1.856 & 1.884 & 1.927 & 1.932 & 1.928 & 1.860 & 1.895 & 1.909 & 1.891 \\
\hline AlIV & 0.130 & 0.149 & 0.144 & 0.105 & 0.073 & 0.068 & 0.065 & 0.140 & 0.105 & 0.091 & 0.108 \\
\hline $\mathrm{Al} V \mathrm{I}$ & 0.063 & 0.000 & 0.015 & 0.000 & 0.011 & 0.011 & 0.000 & 0.012 & 0.002 & 0.026 & 0.000 \\
\hline $\mathrm{Fe}^{2+}$ & 0.357 & 0.276 & 0.173 & 0.468 & 0.182 & 0.639 & 0.849 & 0.231 & 0.439 & 0.164 & 0.269 \\
\hline $\mathrm{Fe}^{3+}$ & 0.018 & 0.059 & 0.062 & 0.025 & 0.028 & 0.001 & 0.003 & 0.035 & 0.038 & 0.041 & 0.053 \\
\hline $\mathrm{Mg}$ & 0.805 & 0.787 & 0.872 & 0.867 & 0.959 & 0.835 & 0.601 & 0.850 & 0.822 & 0.939 & 0.912 \\
\hline $\mathrm{Mn}$ & 0.010 & 0.008 & 0.006 & 0.013 & 0.004 & 0.012 & 0.019 & 0.007 & 0.013 & 0.007 & 0.007 \\
\hline $\mathrm{Ti}$ & 0.041 & 0.060 & 0.040 & 0.047 & 0.016 & 0.035 & 0.037 & 0.047 & 0.043 & 0.013 & 0.035 \\
\hline $\mathrm{Cr}$ & 0.002 & 0.000 & 0.015 & 0.001 & 0.020 & 0.000 & 0.000 & 0.019 & 0.000 & 0.018 & 0.001 \\
\hline Ca & 0.670 & 0.798 & 0.791 & 0.585 & 0.762 & 0.454 & 0.492 & 0.778 & 0.620 & 0.771 & 0.709 \\
\hline $\mathrm{Na}$ & 0.034 & 0.029 & 0.027 & 0.015 & 0.018 & 0.014 & 0.013 & 0.021 & 0.022 & 0.021 & 0.015 \\
\hline \multicolumn{12}{|c|}{ Pyroxene Components, Mol \% } \\
\hline $\mathrm{Ca}$ & 36.2 & 41.6 & 41.7 & 30.1 & 39.5 & 23.6 & 25.3 & 41.1 & 32.3 & 40.3 & 36.5 \\
\hline $\mathrm{Mg}$ & 43.5 & 41.0 & 45.9 & 44.6 & 49.7 & 43.3 & 30.9 & 44.9 & 42.9 & 49.0 & 46.9 \\
\hline $\mathrm{Fe}_{\mathrm{T}}$ & 20.3 & 17.4 & 12.4 & 25.3 & 10.9 & 33.2 & 43.8 & 14.0 & 24.8 & 10.7 & 16.6 \\
\hline Others & 13.0 & 14.9 & 14.4 & 10.5 & 7.5 & 6.8 & 6.5 & 14.0 & 10.5 & 9.8 & 10.8 \\
\hline
\end{tabular}

Hawaiian alkalic basalts erupted during the alkalic stage (Keil et al., 1972; Fodor et al., 1975). We therefore infer that these alkalic flows ( 1 and 2 ), and presumably Flow Unit 3 as well, erupted during the post-caldera alkalic stage of eruption.

\section{Suiko Seamount: Tholeiitic Basalts}

Sample 433C-10-4, 11-17 cm, Olivine Tholeiite

This sample, from Flow Unit $4 \mathrm{~F}$, is highly vesicular, and has an intersertal texture. Olivine phenocrysts are 
TABLE 8 - Continued

\begin{tabular}{|c|c|c|c|c|c|c|c|c|c|c|c|}
\hline 12 & 13 & 14 & 15 & 16 & 17 & 18 & 19 & 20 & 21 & 22 & 23 \\
\hline 51.87 & 49.93 & 50.52 & 51.30 & 51.90 & 50.33 & 48.99 & 53.24 & 52.27 & 52.72 & 52.09 & 51.11 \\
\hline 0.71 & 1.46 & 1.17 & 0.99 & 0.54 & 1.20 & 0.80 & 0.50 & 0.70 & 0.79 & 1.04 & 1.10 \\
\hline 2.15 & 2.78 & 3.78 & 1.95 & 1.64 & 4.25 & 1.21 & 1.07 & 2.61 & 1.18 & 1.88 & 2.19 \\
\hline 7.73 & 12.86 & 9.38 & 12.91 & 9.98 & 7.70 & 25.36 & 17.55 & 7.82 & 19.78 & 10.19 & 11.22 \\
\hline 0.14 & 0.32 & 0.15 & 0.30 & 0.25 & 0.16 & 0.52 & 0.35 & 0.20 & 0.42 & 0.29 & 0.25 \\
\hline 17.01 & 14.93 & 16.31 & 15.11 & 19.70 & 16.91 & 10.45 & 24.04 & 17.86 & 21.01 & 16.89 & 15.58 \\
\hline 19.38 & 16.74 & 18.67 & 16.87 & 14.69 & 18.32 & 10.91 & 3.63 & 17.82 & 4.85 & 17.66 & 18.16 \\
\hline 0.25 & 0.23 & 0.28 & 0.30 & 0.20 & 0.35 & 0.28 & 0.07 & 0.25 & 0.13 & 0.21 & 0.26 \\
\hline 0.08 & 0.00 & 0.23 & 0.05 & 0.18 & 0.94 & 0.02 & 0.00 & 0.95 & 0.00 & 0.10 & 0.00 \\
\hline 99.32 & 99.25 & 100.49 & 99.78 & 99.08 & 100.16 & 98.54 & $100.45^{n}$ & 100.48 & 100.88 & 100.35 & 99.87 \\
\hline 1.918 & 1.885 & 1.856 & 1.925 & 1.919 & 1.846 & 1.950 & 1.945 & 1.909 & 1.947 & 1.921 & 1.905 \\
\hline 0.082 & 0.115 & 0.144 & 0.075 & 0.071 & 0.154 & 0.050 & 0.046 & 0.091 & 0.051 & 0.079 & 0.095 \\
\hline 0.012 & 0.008 & 0.020 & 0.011 & 0.000 & 0.030 & 0.007 & 0.000 & 0.021 & 0.000 & 0.003 & 0.002 \\
\hline 0.192 & 0.365 & 0.216 & 0.376 & 0.258 & 0.180 & 0.828 & 0.513 & 0.217 & 0.594 & 0.285 & 0.300 \\
\hline 0.047 & 0.041 & 0.072 & 0.029 & 0.051 & 0.056 & 0.016 & 0.024 & 0.022 & 0.017 & 0.030 & 0.050 \\
\hline 0.937 & 0.840 & 0.893 & 0.845 & 1.086 & 0.924 & 0.620 & 1.309 & 0.972 & 1.156 & 0.929 & 0.866 \\
\hline 0.004 & 0.010 & 0.005 & 0.010 & 0.008 & 0.005 & 0.018 & 0.011 & 0.006 & 0.013 & 0.009 & 0.008 \\
\hline 0.020 & 0.041 & 0.032 & 0.028 & 0.015 & 0.033 & 0.024 & 0.014 & 0.019 & 0.022 & 0.029 & 0.031 \\
\hline 0.002 & 0.000 & 0.007 & 0.001 & 0.005 & 0.027 & 0.001 & 0.000 & 0.027 & 0.000 & 0.003 & 0.000 \\
\hline 0.768 & 0.677 & 0.735 & 0.678 & 0.582 & 0.720 & 0.465 & 0.142 & 0.697 & 0.192 & 0.698 & 0.725 \\
\hline 0.018 & 0.017 & 0.020 & 0.022 & 0.014 & 0.025 & 0.022 & 0.005 & 0.018 & 0.009 & 0.015 & 0.019 \\
\hline 39.5 & 35.2 & 38.4 & 35.2 & $29.4^{\prime}$ & 38.3 & 24.1 & 7.1 & 36.5 & 9.8 & 36.0 & 37.4 \\
\hline 48.2 & 43.7 & 46.6 & 43.8 & 54.9 & 49.2 & 23.1 & 65.9 & 50.9 & 59.0 & 47.8 & 44.6 \\
\hline 12.3 & 21.1 & 15.0 & 21.0 & 15.6 & 12.6 & 43.8 & 27.0 & 12.5 & 31.2 & 16.2 & 18.0 \\
\hline 8.2 & 11.5 & 14.4 & 7.5 & 7.1 & 15.4 & 5.0 & 4.6 & 9.1 & 5.1 & 7.8 & 9.5 \\
\hline
\end{tabular}

Legend

\begin{tabular}{|c|c|c|c|}
\hline 35 & 36 & 37 & 38 \\
\hline 49.82 & 48.96 & 48.25 & 47.41 \\
\hline 1.35 & 1.91 & 2.61 & 2.84 \\
\hline 1.74 & 3.21 & 4.18 & 4.04 \\
\hline 19.71 & 12.20 & 10.07 & 13.44 \\
\hline 0.40 & - & 0.23 & 0.26 \\
\hline 11.75 & 14.96 & 13.46 & 12.23 \\
\hline 15.41 & 17.56 & 20.05 & 18.39 \\
\hline 0.27 & 0.49 & 0.40 & 0.46 \\
\hline 0.00 & 0.02 & 0.33 & 0.03 \\
\hline 100.45 & 99.31 & 99.58 & 99.10 \\
\hline 1.915 & 1.845 & 1.815 & 1.814 \\
\hline 0.079 & 0.143 & 0.185 & 0.182 \\
\hline 0.000 & 0.000 & 0.000 & 0.000 \\
\hline 0.613 & 0.315 & 0.260 & 0.378 \\
\hline 0.021 & 0.070 & 0.056 & 0.052 \\
\hline 0.673 & 0.840 & 0.755 & 0.697 \\
\hline 0.013 & - & 0.007 & 0.008 \\
\hline 0.039 & 0.054 & 0.074 & 0.082 \\
\hline 0.000 & 0.001 & 0.010 & 0.001 \\
\hline 0.635 & 0.709 & 0.808 & 0.754 \\
\hline 0.020 & 0.036 & 0.029 & 0.034 \\
\hline 32.7 & 36.7 & 43.0 & 40.0 \\
\hline 34.7 & 43.4 & 40.2 & 37.1 \\
\hline 32.6 & 19.9 & 16.9 & 22.9 \\
\hline 7.9 & 14.3 & 18.5 & 18.2 \\
\hline
\end{tabular}

\begin{tabular}{|c|c|c|c|}
\hline Column & $\begin{array}{c}\text { Sample } \\
\text { (Interval in } \mathrm{cm} \text { ) }\end{array}$ & $\begin{array}{l}\text { Flow } \\
\text { Unit }\end{array}$ & Rock Type \\
\hline 1 & $433 \mathrm{~A}-21-4,129-138$ & 1 & Alkalic basalt \\
\hline 2 & $433 \mathrm{~A}-21-4,129-138$ & 1 & Alkalic basalt \\
\hline 3 & $433 \mathrm{~B}-5-2,61-68$ & 1 & Alkalic basalt \\
\hline 4 & $433 \mathrm{~B}-5-3,85-90$ & 2 & Alkalic basalt \\
\hline 5 & $433 \mathrm{~B}-5-3,85-90$ & 2 & Alkalic basalt \\
\hline 6 & $433 C-4-1,30-38$ & 2 & Alkalic basalt \\
\hline 7 & $433 C-12-3,57-65$ & 9 & Tholeiite \\
\hline 8 & $433 C-12-3,57-65$ & 9 & Tholeiite \\
\hline 9 & $433 \mathrm{C}-13-2,55-66$ & 10 & Plagioclase tholeiite \\
\hline 10 & $433 C-13-2,55-66$ & 10 & Plagioclase tholeiite \\
\hline 11 & $433 C-13-2,55-66$ & 10 & Plagioclase tholeiite \\
\hline 12 & $433 \mathrm{C}-14-3,8-15$ & $11 \mathrm{~B}$ & Plagioclase tholeiite \\
\hline 13 & $433 \mathrm{C}-14-3,8-15$ & $11 \mathrm{~B}$ & Plagioclase tholeiite \\
\hline 14 & $433 C-15-6,16-31$ & 13 & Tholeiite \\
\hline 15 & $433 C-15-6,16-31$ & 13 & Tholeiite \\
\hline 16 & $433 \mathrm{C}-19-5,57-65$ & $15 \mathrm{~A}$ & Tholeiite \\
\hline 17 & $433 C-19-5,57-65$ & $15 \mathrm{~A}$ & Tholeiite \\
\hline 18 & $433 C-19-5,57-65$ & $15 \mathrm{~A}$ & Tholeiite \\
\hline 19 & $433 \mathrm{C}-24-7,133-139$ & 19 & Tholeiite picrite \\
\hline 20 & $433 \mathrm{C}-24-7,133-139$ & 19 & Tholeiite picrite \\
\hline 21 & $433 \mathrm{C}-24-7,133-139$ & 19 & Tholeiite picrite \\
\hline 22 & $433 \mathrm{C}-24-7,133-139$ & 19 & Tholeiite picrite \\
\hline 23 & $433 \mathrm{C}-28-2,73-80$ & 25 & Plagioclase tholeiite \\
\hline 24 & $433 \mathrm{C}-28-2,73-80$ & 25 & Plagioclase tholeiite \\
\hline 25 & $433 \mathrm{C}-31-1,28-34$ & 27 & $\begin{array}{l}\text { Plagioclase-olivine } \\
\text { tholeiite }\end{array}$ \\
\hline 26 & $433 \mathrm{C}-34-2,103-111$ & 33 & Tholeiite picrite \\
\hline 27 & $433 \mathrm{C}-34-2,103-111$ & 33 & Tholeiite picrite \\
\hline 28 & $433 \mathrm{C}-37-3,79-87$ & 44 & Tholeiite \\
\hline 29 & $433 \mathrm{C}-37-3,79-87$ & 44 & Tholeiite \\
\hline 30 & $433 \mathrm{C}-37-3,79-87$ & 44 & Tholeiite \\
\hline 31 & $433 \mathrm{C}-38-1,67-76$ & $45 \mathrm{~B}$ & Olivine tholeiite \\
\hline 32 & $433 C-38-1,67-76$ & $45 \mathrm{~B}$ & Olivine tholeiite \\
\hline 33 & $433 C-42-3,11-20$ & 53 & Plagioclase tholeiite \\
\hline 34 & $433 \mathrm{C}-42-3,11-20$ & 53 & Plagioclase tholeiite \\
\hline 35 & $433 \mathrm{C}-42-3,11-20$ & 53 & Plagioclase tholeiite \\
\hline 36 & $433 C-47-5,92-100$ & 64 & Tholeiite \\
\hline 37 & $433 \mathrm{C}-49-2,17-24$ & 66 & Tholeiite \\
\hline 38 & $433 \mathrm{C}-49-2,17-24$ & 66 & Tholeiite \\
\hline
\end{tabular}

\section{Crystal Analyzed}

Colorless phenocryst core Brown phenocryst rim Colorless phenocryst core Phenocryst core Groundmass Phenocryst rim Microphenocryst Groundmass Phenocryst core Phenocryst core Groundmass Phenocryst core Groundmass

Microphenocryst core Groundmass

Microphenocryst core Microphenocryst core Groundmass

Microphenocryst Microphenocryst

Groundmass

Groundmass

Phenocryst core

Groundmass

Groundmass

Groundmass

Groundmass

Microphenocryst core Ground mass

Groundmass

Ground mass

Ground mass

Phenocryst core

Groundmass

Groundmass

Groundmass

Groundmas

Groundmass 
TABLE 9

Representative Chromite Analyses from Leg 55 (Oxides wt. \%)

\begin{tabular}{|c|c|c|c|c|c|c|c|c|c|c|c|c|c|c|c|}
\hline & 1 & 2 & 3 & 4 & 5 & 6 & 7 & 8 & 9 & 10 & 11 & 12 & 13 & 14 & 15 \\
\hline $\mathrm{Al}_{2} \mathrm{O}_{3}$ & 23.86 & 20.49 & 26.45 & 18.79 & 5.75 & 4.07 & 3.21 & 2.54 & 20.02 & 20.15 & 8.16 & 21.19 & 14.02 & 18.53 & 13.28 \\
\hline $\mathrm{TiO}_{2}$ & 2.49 & 4.77 & 1.91 & 4.76 & 14.85 & 7.65 & 20.22 & 22.29 & 1.20 & 1.39 & 10.85 & 2.02 & 4.86 & 2.04 & 5.53 \\
\hline $\mathrm{FeO}$ & 19.04 & 26.34 & 27.14 & 29.29 & 40.27 & 43.87 & 45.76 & 47.69 & 23.82 & 15.86 & 34.44 & 21.69 & 25.71 & 22.31 & 30.02 \\
\hline $\mathrm{Fe}_{2} \mathrm{O}_{3}$ & 17.46 & 17.13 & 12.50 & 16.94 & 19.01 & 20.05 & 20.01 & 20.31 & 9.57 & 5.11 & 25.71 & 7.53 & 10.05 & 10.87 & 9.03 \\
\hline $\mathrm{MnO}$ & 0.52 & 0.55 & 0.57 & 0.63 & 0.71 & 0.64 & 0.67 & 0.62 & 0.69 & 0.65 & 0.54 & 0.82 & 0.80 & 0.65 & 0.71 \\
\hline $\mathrm{MgO}$ & 12.08 & 7.98 & 6.65 & 5.71 & 3.24 & 2.64 & 2.57 & 2.49 & 7.68 & 13.18 & 5.18 & 9.39 & 7.62 & 8.92 & 5.38 \\
\hline $\mathrm{Cr}_{2} \mathrm{O}_{3}$ & 25.27 & 21.97 & 25.10 & 22.59 & 15.77 & 11.83 & 7.17 & 3.68 & 37.30 & 44.45 & 15.63 & 36.60 & 35.87 & 36.47 & 35.88 \\
\hline TOTAL & 100.72 & 99.23 & 100.31 & 98.71 & 99.61 & 100.75 & 99.62 & 99.63 & 100.28 & 100.79 & 100.51 & 99.25 & 98.93 & 99.79 & 99.82 \\
\hline \multicolumn{16}{|c|}{ Cations, Oxygen $=4$} \\
\hline $\mathrm{Al}$ & 0.866 & 0.784 & 0.985 & 0.739 & 0.243 & 0.172 & 0.138 & 0.109 & 0.760 & 0.733 & 0.334 & 0.798 & 0.553 & 0.706 & 0.530 \\
\hline $\mathrm{Fe}^{3+}$ & 0.404 & 0.419 & 0.297 & 0.425 & 0.512 & 0.541 & 0.548 & 0.559 & 0.232 & 0.119 & 0.671 & 0.181 & 0.253 & 0.264 & 0.230 \\
\hline $\mathrm{C}_{\mathrm{I}}$ & 0.615 & 0.564 & 0.627 & 0.596 & 0.466 & 0.335 & 0.206 & 0.106 & 0.950 & 1.084 & 0.429 & 0.924 & 0.949 & 0.931 & 0.959 \\
\hline $\mathrm{Ti}$ & 0.058 & 0.116 & 0.045 & 0.119 & 0.400 & 0.476 & 0.554 & 0.613 & 0.029 & 0.032 & 0.283 & 0.049 & 0.122 & 0.050 & 0.141 \\
\hline $\mathrm{Fe}^{2+}$ & 0.490 & 0.715 & 0.717 & 0.818 & 1.205 & 1.315 & 1.394 & 1.458 & 0.642 & 0.409 & 0.999 & 0.579 & 0.720 & 0.602 & 0.849 \\
\hline $\mathrm{Mn}$ & 0.014 & 0.015 & 0.015 & 0.018 & 0.022 & 0.019 & 0.021 & 0.019 & 0.019 & 0.017 & 0.016 & 0.022 & 0.023 & 0.018 & 0.020 \\
\hline $\mathrm{Mg}$ & 0.554 & 0.386 & 0.313 & 0.284 & 0.173 & 0.141 & 0.139 & 0.136 & 0.369 & 0.606 & 0.268 & 0.447 & 0.380 & 0.429 & 0.271 \\
\hline $\begin{array}{c}\mathrm{Mg} /(\mathrm{Mg}+ \\
\left.\mathrm{Fe}^{2+}\right)\end{array}$ & .531 & .351 & .304 & .258 & .126 & .097 & .091 & .085 & .365 & .597 & .212 & .436 & .345 & .416 & .242 \\
\hline $\begin{array}{c}\mathrm{Cr} /(\mathrm{Cr}+ \\
\mathrm{Al})\end{array}$ & .415 & .418 & .389 & .446 & .657 & .661 & .599 & .493 & .556 & .597 & .562 & .537 & .632 & .569 & .644 \\
\hline
\end{tabular}

\begin{tabular}{|c|c|c|c|c|c|c|c|}
\hline & 16 & 17 & 18 & 19 & 20 & 21 & 22 \\
\hline $\mathrm{Al}_{2} \mathrm{O}_{3}$ & 18.05 & 13.96 & 16.46 & 21.38 & 11.92 & 5.51 & 3.10 \\
\hline $\mathrm{TiO}_{2}$ & 1.04 & 1.84 & 3.24 & 4.34 & 9.70 & 13.64 & 15.62 \\
\hline $\mathrm{FeO}$ & 16.45 & 27.32 & 24.79 & 22.98 & 34.32 & 38.04 & 42.32 \\
\hline $\mathrm{Fe}_{2} \mathrm{O}_{3}$ & 6.32 & 9.31 & 18.11 & 11.98 & 8.03 & 10.09 & 17.08 \\
\hline $\mathrm{MnO}$ & 0.75 & 0.81 & 0.81 & 0.52 & 0.69 & 1.05 & 0.98 \\
\hline $\mathrm{MgO}$ & 12.34 & 5.24 & 7.90 & 10.26 & 4.58 & 3.74 & 1.67 \\
\hline $\mathrm{Cr}_{2} \mathrm{O}_{3}$ & 46.04 & 42.61 & 29.86 & 28.62 & 29.03 & 27.11 & 17.61 \\
\hline TOTAL & 100.98 & 101.08 & 101.17 & 100.08 & 98.28 & 99.18 & 98.37 \\
\hline \multicolumn{8}{|c|}{ Cations, Oxygen $=4$} \\
\hline Al & 0.665 & 0.549 & 0.631 & 0.795 & 0.488 & 0.232 & 0.136 \\
\hline $\mathrm{Fe}^{3+}$ & 0.149 & 0.234 & 0.443 & 0.285 & 0.210 & 0.271 & 0.477 \\
\hline $\mathrm{Cr}$ & 1.137 & 1.124 & 0.767 & 0.714 & 0.796 & 0.765 & 0.516 \\
\hline $\mathrm{Ti}$ & 0.024 & 0.046 & 0.079 & 0.103 & 0.253 & 0.366 & 0.436 \\
\hline $\mathrm{Fe}^{2+}$ & 0.430 & 0.763 & 0.674 & 0.607 & 0.996 & 1.135 & 1.313 \\
\hline $\mathrm{Mn}$ & 0.020 & 0.023 & 0.022 & 0.014 & 0.020 & 0.032 & 0.031 \\
\hline $\mathrm{Mg}$ & 0.575 & 0.261 & 0.383 & 0.483 & 0.237 & 0.199 & 0.092 \\
\hline $\begin{array}{c}\mathrm{Mg} /(\mathrm{Mg}+ \\
\left.\mathrm{Fe}^{2+}\right)\end{array}$ & .572 & .255 & .362 & .443 & .192 & .149 & .065 \\
\hline $\begin{array}{c}\mathrm{Cr} /(\mathrm{Cr}+ \\
\text { Al) }\end{array}$ & .631 & .672 & .549 & .473 & .620 & .767 & .791 \\
\hline
\end{tabular}

\begin{tabular}{|c|c|c|c|}
\hline Column & $\begin{array}{c}\text { Sample } \\
\text { (Interval in cm) }\end{array}$ & $\begin{array}{l}\text { Flow } \\
\text { Unit } \\
\end{array}$ & Rock Type \\
\hline 1 & $433 \mathrm{~B}-5-3,85-90$ & 2 & Alkalic basalt \\
\hline 2 & $433 \mathrm{~B}-5-3,85-90$ & 2 & Alkalic basalt \\
\hline 3 & $433 \mathrm{C}-4-1,30-38$ & 2 & Alkalic basalt \\
\hline 4 & $433 \mathrm{C}-4-1,30-38$ & 2 & Alkalic basalt \\
\hline 5 & $433 \mathrm{C}-4-1,30-38$ & 2 & Alkalic basalt \\
\hline 6 & $433 C-4-1,30-38$ & 2 & Alkalic basalt \\
\hline 7 & $433 C-4-1,30-38$ & 2 & Alka lic basalt \\
\hline 8 & $433 \mathrm{C}-4-1,30-38$ & 2 & Alkalic basalt \\
\hline 9 & $433 \mathrm{C}-10-4,11-17$ & $4 \mathrm{~F}$ & Olivine tholeiite \\
\hline 10 & $433 C-24-7,133-139$ & 19 & Tholeiitic picrite \\
\hline 11 & $433 \mathrm{C}-31-1,28-34$ & 27 & $\begin{array}{l}\text { Plagioclase-olivine } \\
\text { tholeiite }\end{array}$ \\
\hline 12 & $433 \mathrm{C}-34-2,103-111$ & 33 & Tholeiitic picrite \\
\hline 13 & $433 \mathrm{C}-34-2,103-111$ & 33 & Tholeiitic picrite \\
\hline 14 & $433 \mathrm{C}-37-3,79-87$ & 44 & Tholeiite \\
\hline 15 & $433 \mathrm{C}-37-3,79-87$ & 44 & Tholeiite \\
\hline 16 & $433 C-38-1,67-76$ & $45 \mathrm{~B}$ & Olivine tholeiite \\
\hline 17 & $433 \mathrm{C}-38-1,67-76$ & $45 \mathrm{~B}$ & Olivine tholeiite \\
\hline 18 & $433 \mathrm{C}-47-5,92-100$ & 64 & Tholeiite \\
\hline 19 & $433 C-49-2,17-24$ & 66 & Tholeiite \\
\hline 20 & $433 \mathrm{C}-49-2,17-24$ & 66 & Tholeiite \\
\hline 21 & $433 \mathrm{C}-49-2,17-24$ & 66 & Tholeiite \\
\hline 22 & $433 \mathrm{C}-49-2,17-24$ & 66 & Tholeiite \\
\hline
\end{tabular}

Sample 433C-13-2, 55-66 cm, Plagioclase Tholeiite

This sample, from the interior of Flow Unit 10, has diabasic to intersertal texture. It contains phenocrysts of plagioclase $\left(\mathrm{An}_{69} \mathrm{Or}_{1}-\mathrm{An}_{63} \mathrm{Or}_{1}\right)$, sector-zoned clinopyroxene $\left(\mathrm{Wo}_{41} \mathrm{En}_{48} \mathrm{Fs}_{11}-\mathrm{Wo}_{38} \mathrm{En}_{51} \mathrm{Fs}_{10}\right.$ and $\mathrm{Wo}_{44} \mathrm{En}_{45}$ $\mathrm{Fs}_{11}$ ), and olivine completely altered to clays. Compared to low-Ca pyroxene sectors, high-Ca pyroxene sectors have high contents of $\mathrm{Al}_{2} \mathrm{O}_{3}$ (4.8-4.9 \% versus 1.7-2.3 \%), $\mathrm{TiO}_{2}(1.3-1.5 \%$ versus $0.6-0.7 \%)$, and $\mathrm{Cr}_{2} \mathrm{O}_{3}$ (0.85-1.24 \% versus $0.20-0.57 \%$ ), and lower $\mathrm{SiO}_{2}$ contents (48.6-49.15\% versus 51.9-52.4\%). These sectorzoned pyroxenes are similar to those from Flow Unit 1 and to those described by Wass (1973), except that these have much lower $\mathrm{Al}_{2} \mathrm{O}_{3}$ and $\mathrm{TiO}_{2}$ contents and much higher $\mathrm{SiO}_{2}$ contents than the sector-zoned pyroxenes found in alkalic basalts. The groundmass consists of plagioclase laths $\left(\mathrm{An}_{49} \mathrm{Or}_{2}-\mathrm{An}_{31} \mathrm{Or}_{5}\right)$, clinopyroxene $\left(\mathrm{Wo}_{41} \mathrm{En}_{45} \mathrm{Fs}_{14}-\mathrm{Wo}_{35} \mathrm{En}_{35} \mathrm{Fs}_{30}\right)$, equant exsolved titanomagnetite $\left(\mathrm{Mt}_{18}-\mathrm{Mt}_{25}\right)$, ilmenite $\left(\mathrm{Il}_{94}-\mathrm{Il}_{95}\right)$, and rare pyrite. The groundmass clinopyroxene contains 4 to 11 per cent total "other" components. 
TABLE 10

Clinopyroxene Analyses from Sample 433A-20-1, 30-36 cm (Oxides wt. \%)

\begin{tabular}{|c|c|c|c|c|c|c|c|c|c|c|c|c|}
\hline & 1 & 2 & 3 & 4 & 5 & 6 & 7 & 8 & 9 & 10 & 11 & 12 \\
\hline $\mathrm{SiO}_{2}$ & 49.85 & 50.65 & 50.06 & 46.54 & 46.16 & 51.18 & 50.66 & 50.89 & 45.89 & 47.85 & 51.47 & 46.45 \\
\hline $\mathrm{TiO}_{2}$ & 1.55 & 1.01 & 1.19 & 2.31 & 2.63 & 1.05 & 1.02 & 1.27 & 2.86 & 1.96 & 0.95 & 2.73 \\
\hline $\mathrm{Al}_{2} \mathrm{O}_{3}$ & 3.04 & 2.58 & 3.02 & 5.32 & 5.51 & 2.55 & 2.54 & 2.44 & 6.68 & 5.37 & 2.40 & 6.40 \\
\hline $\mathrm{FeO}$ & 10.49 & 9.73 & 10.07 & 9.93 & 9.65 & 10.26 & 10.25 & 10.60 & 10.70 & 9.93 & 9.68 & 10.55 \\
\hline $\mathrm{MnO}$ & 0.28 & 0.25 & 0.22 & 0.26 & 0.22 & 0.26 & 0.23 & 0.25 & 0.23 & 0.22 & 0.20 & 0.25 \\
\hline $\mathrm{MgO}$ & 14.66 & 15.75 & 15.19 & 13.27 & 13.05 & 16.24 & 15.78 & 15.14 & 12.61 & 13.46 & 16.24 & 12.64 \\
\hline $\mathrm{CaO}$ & 19.85 & 19.16 & 19.59 & 20.58 & 20.82 & 18.34 & 18.38 & 18.91 & 19.78 & 19.96 & 18.26 & 20.02 \\
\hline $\mathrm{Na}_{2} \mathrm{O}$ & 0.34 & 0.34 & 0.31 & 0.45 & 0.48 & 0.30 & 0.27 & 0.35 & 0.56 & 0.50 & 0.37 & 0.50 \\
\hline $\mathrm{Cr}_{2} \mathrm{O}_{3}$ & 0.01 & 0.10 & 0.08 & 0.20 & 0.24 & 0.08 & 0.05 & 0.00 & 0.08 & 0.10 & 0.11 & 0.14 \\
\hline TOTAL & 100.07 & 99.57 & 99.73 & 98.86 & 98.76 & 100.26 & 99.18 & 99.85 & 99.39 & 99.35 & 99.68 & 99.68 \\
\hline \multicolumn{13}{|c|}{ Cations, Oxygen $=6$} \\
\hline $\mathrm{Si}$ & 1.860 & 1.885 & 1.865 & 1.759 & 1.748 & 1.891 & 1.894 & 1.897 & 1.729 & 1.795 & 1.909 & 1.745 \\
\hline $\mathrm{Al}^{\mathrm{IV}}$ & 0.134 & 0.113 & 0.133 & 0.237 & 0.246 & 0.109 & 0.106 & 0.103 & 0.271 & 0.205 & 0.091 & 0.255 \\
\hline AlVI & 0.000 & 0.000 & 0.000 & 0.000 & 0.000 & 0.002 & 0.006 & 0.004 & 0.025 & 0.032 & 0.014 & 0.029 \\
\hline $\mathrm{Fe}^{2+}$ & 0.256 & 0.225 & 0.228 & 0.181 & 0.181 & 0.249 & 0.261 & 0.278 & 0.214 & 0.216 & 0.253 & 0.228 \\
\hline $\mathrm{Fe}^{3+}$ & 0.071 & 0.078 & 0.086 & 0.133 & 0.124 & 0.068 & 0.060 & 0.053 & 0.123 & 0.096 & 0.048 & 0.104 \\
\hline $\mathrm{Mg}$ & 0.815 & 0.873 & 0.843 & 0.747 & 0.737 & 0.894 & 0.879 & 0.841 & 0.708 & 0.752 & 0.898 & 0.708 \\
\hline $\mathrm{Mn}$ & 0.009 & 0.008 & 0.007 & 0.008 & 0.007 & 0.008 & 0.007 & 0.008 & 0.007 & 0.007 & 0.006 & 0.008 \\
\hline $\mathrm{Ti}$ & 0.043 & 0.028 & 0.033 & 0.066 & 0.075 & 0.029 & 0.029 & 0.036 & 0.081 & 0.055 & 0.026 & 0.077 \\
\hline $\mathrm{Cr}$ & 0.000 & 0.003 & 0.002 & 0.006 & 0.007 & 0.002 & 0.001 & 0.000 & 0.002 & 0.003 & 0.003 & 0.004 \\
\hline $\mathrm{Ca}$ & 0.793 & 0.764 & 0.782 & 0.833 & 0.845 & 0.726 & 0.736 & 0.755 & 0.798 & 0.802 & 0.726 & 0.806 \\
\hline $\mathrm{Na}$ & 0.025 & 0.025 & 0.022 & 0.033 & 0.035 & 0.021 & 0.020 & 0.025 & 0.041 & 0.036 & 0.027 & 0.036 \\
\hline \multicolumn{13}{|c|}{ Pyroxene Components, Mol\% } \\
\hline $\mathrm{Ca}$ & 41.0 & 39.4 & 40.3 & 44.0 & 44.8 & 37.5 & 38.0 & 39.2 & 43.3 & 43.0 & 37.7 & 43.7 \\
\hline $\mathrm{Mg}$ & 42.1 & 45.0 & 43.5 & 39.4 & 39.1 & 46.2 & 45.4 & 43.6 & 38.4 & 40.3 & 46.6 & 38.4 \\
\hline $\mathrm{Fe}_{\mathrm{T}}$ & 16.9 & 15.6 & 16.2 & 16.6 & 16.1 & 16.3 & 16.6 & 17.2 & 18.3 & 16.7 & 15.7 & 17.9 \\
\hline Others & 13.4 & 11.3 & 13.3 & 23.7 & 24.6 & 10.9 & 10.5 & 10.3 & 27.1 & 20.5 & 9.1 & 25.5 \\
\hline
\end{tabular}

\section{Sample 433C-14-3, 8-15 cm, Plagioclase Tholeiite}

Sample $433 \mathrm{C}-14-3,8-15 \mathrm{~cm}$, from the interior of Flow Unit 11B, has an intersertal texture with about 15 $\%$ vesicles. Phenocrysts and microphenocrysts are plagioclase $\left(\mathrm{An}_{76} \mathrm{Or}_{0}-\mathrm{An}_{64} \mathrm{Or}_{1}\right)$, clinopyroxene $\left(\mathrm{Wo}_{40} \mathrm{En}_{48}\right.$ $\mathrm{Fs}_{12}-\mathrm{Wo}_{40} \mathrm{En}_{46} \mathrm{Fs}_{14}$ ), and olivine altered to iddingsite. The groundmass contains plagioclase laths $\left(\mathrm{An}_{55} \mathrm{Or}_{1-}\right.$ $\left.\mathrm{An}_{43} \mathrm{Or}_{2}\right)$, clinopyroxene $\left(\mathrm{Wo}_{39} \mathrm{En}_{46} \mathrm{Fs}_{15}-\mathrm{Wo}_{30} \mathrm{En}_{43} \mathrm{Fs}_{27}\right)$, skeletal exsolved titanomagnetite $\left(\mathrm{Mt}_{11}-\mathrm{Mt}_{34}\right)$, and ilmenite $\left(\mathrm{Il}_{95}-\mathrm{Il}_{98}\right)$. The clinopyroxene phenocrysts contain 8 to 11 per cent total "other" components; the groundmass crystals contain 9 to 14 per cent.

\section{Sample 433C-15-6, 16-31 cm, Tholeiite}

Sample $433 \mathrm{C}-15-6,16-31 \mathrm{~cm}$, from the interior of Flow Unit 13, has pilotaxitic texture and contains glomerocrysts of plagioclase $\left(\mathrm{An}_{84} \mathrm{Or}_{0}-\mathrm{An}_{58} \mathrm{Or}_{1}\right)$, clinopyroxene $\left(\mathrm{Wo}_{41} \mathrm{En}_{47} \mathrm{Fs}_{11}\right)$, and olivine that is completely altered to clays, and clinopyroxene microphenocrysts (cores $=\mathrm{Wo}_{34} \mathrm{En}_{51} \mathrm{Fs}_{14}-\mathrm{Wo}_{39} \mathrm{En}_{45} \mathrm{Fs}_{16}$, rims $=\mathrm{Wo}_{40}$ $\left.\mathrm{En}_{43} \mathrm{Fs}_{17}-\mathrm{Wo}_{39} \mathrm{En}_{41} \mathrm{Fs}_{20}\right)$. The microphenocrysts fall into two groups: one that has high contents of $\mathrm{Al}_{2} \mathrm{O}_{3}$ (3.64.25 wt. $\%), \mathrm{TiO}_{2}(1.2-1.65$ wt. $\%), \mathrm{Na}_{2} \mathrm{O}(0.25-0.34$ wt. \%), and $\mathrm{Cr}_{2} \mathrm{O}_{3}\left(0.17-0.23\right.$ wt. \%), and low $\mathrm{SiO}_{2}$ contents (49.6-50.5 wt. \%), and a second group with low contents of $\mathrm{Al}_{2} \mathrm{O}_{3}(1.7-1.8 \mathrm{wt} \%), \mathrm{TiO}_{2}(0.64-0.70$ wt. \%), $\mathrm{Na}_{2} \mathrm{O}\left(0.15-0.16\right.$ wt. \%), and $\mathrm{Cr}_{2} \mathrm{O}_{3}(0.03-0.05$ wt. \%), and high $\mathrm{SiO}_{2}$ contents (52.2-52.9 wt. \%). These chemical groups are nearly identical in composition to those found in the sector-zoned clinopyroxene in Sample 433C-13-2, 55-66 cm. The groundmass contains plagioclase $\left(\mathrm{An}_{56} \mathrm{Or}_{1}-\mathrm{An}_{12} \mathrm{Or}_{32}\right)$, clinopyroxene $\left(\mathrm{Wo}_{38}\right.$ $\left.\mathrm{En}_{45} \mathrm{Fs}_{17}-\mathrm{Wo}_{35} \mathrm{En}_{44} \mathrm{Fs}_{21}\right)$, ilmenite ( $\left.\mathrm{Il}_{96}\right)$, and equant titanomagnetite $\left(\mathrm{Mt}_{19}-\mathrm{Mt}_{36}\right)$ with minor ilmenite exsolu- tion. Some clinopyroxene phenocrysts enclose plagioclase grains, indicating that plagioclase may be the liquidus phase; the time of olivine crystallization is not known.

\section{Sample 433C-19-5, 57-65 cm, Tholeiite}

This sample, from the lower part of the Flow Unit $15 \mathrm{~A}$ interior, has intersertal texture and contains olivine (altered to clays) and phenocrysts and microphenocrysts of plagioclase $\left(\mathrm{An}_{80-65} \mathrm{Or}_{0-1}\right)$, clinopyroxene (cores $=\mathrm{Wo}_{39} \mathrm{En}_{49} \mathrm{Fs}_{12}-\mathrm{Wo}_{31} \mathrm{En}_{53} \mathrm{Fs}_{16}$; rims $=\mathrm{Wo}_{35} \mathrm{En}_{52} \mathrm{Fs}_{13}-$ $\mathrm{Wo}_{39} \mathrm{En}_{47} \mathrm{Fs}_{14}$; "others" = 6-16 mole $\%, \mathrm{Cr}_{2} \mathrm{O}_{3}$ up to 0.94 wt. $\%, \mathrm{Al}_{2} \mathrm{O}_{3}=3.4-4.2$ wt. $\%, \mathrm{TiO}_{2}=1.0-1.5$ wt. $\%$, and $\mathrm{Na}_{2} \mathrm{O}=0.29-0.35$ wt. \%). The Fe-rich microphenocrysts contain lower abundances of all these oxides. The groundmass contains plagioclase laths $\left(\mathrm{An}_{55} \mathrm{Or}_{2}-\mathrm{An}_{22} \mathrm{Or}_{7}\right)$, clinopyroxene $\left(\mathrm{Wo}_{37} \mathrm{En}_{46} \mathrm{Fs}_{17}-\right.$ $\left.\mathrm{Wo}_{24} \mathrm{En}_{32} \mathrm{Fs}_{44}\right)$, equant titanomagnetite $\left(\mathrm{Mt}_{26}-\mathrm{Mt}_{33}\right)$, ilmenite $\left(\mathrm{Il}_{94}-\mathrm{Il}_{97}\right)$, and rare pyrite.

\section{Sample 433C-21-4, 7-13 cm, Tholeiite}

This sample, from the interior of Flow Unit 17, has pilotaxitic texture, and contains glomerocrysts of plagioclase and olivine that is completely altered to iddingsite. The sample is moderately altered: even the plagioclase is altering to clays. The only phases analyzed were groundmass titanomagnetite $\left(\mathrm{Mt}_{46}\right)$ and ilmenite $\left(\mathrm{Il}_{89}\right.$ $\mathrm{Il}_{90}$ ). The ilmenite has a high $\mathrm{MgO}$ content (2.3-4.2 wt. $\%$ ); some of the titanomagnetite contains up to $0.5 \mathrm{wt}$. per cent $\mathrm{Cr}_{2} \mathrm{O}_{3}$. Pyrite is present but rare.

\section{Sample 433C-22-5, 45-52 cm, Plagioclase Tholeiite}

This sample, from the lower part of the interior of Flow Unit 18, has pilotaxitic texture, and contains glomerocrysts of plagioclase $\left(\mathrm{An}_{76-65}-\mathrm{Or}_{0}\right)$ and olivine 
TABLE 11

Holes 433A, 433B, 433C: Mineralogy Summary Table

\begin{tabular}{|c|c|c|c|c|c|c|c|c|}
\hline \multirow{3}{*}{$\begin{array}{c}\text { Sample } \\
\text { (Interval in cm) } \\
\text { (F.U., Rock Type) }\end{array}$} & \multirow{3}{*}{$\begin{array}{l}\text { Olivine }(\mathrm{Fo})^{\mathrm{a}} \\
\text { Temp. }{ }^{\circ} \mathrm{C}\end{array}$} & & & \multirow{3}{*}{$\begin{array}{c}\text { Pyroxene } \\
\text { Wo-En-Fs }\end{array}$} & \multicolumn{4}{|c|}{ Opaques } \\
\hline & & \multirow{2}{*}{\multicolumn{2}{|c|}{$\begin{array}{l}\text { Plagioclase }(\mathrm{An})^{\mathrm{b}} \\
\text { Temp. }\left({ }^{\circ} \mathrm{C}\right)\end{array}$}} & & \multirow{3}{*}{$\begin{array}{c}\text { Mt } \\
\text { Temp. }\left({ }^{\circ} \mathrm{C}\right) \\
26 \text { to } 41\end{array}$} & \multirow{3}{*}{$\begin{array}{c}\mathrm{Il} \\
\log \mathrm{fO}_{2} \\
\text { none }\end{array}$} & \\
\hline & & & & & & & \multicolumn{2}{|c|}{$\mathrm{Cr} \# \quad \mathrm{Mg} \#$} \\
\hline $\begin{array}{l}433 \mathrm{~A}-20-1,30-36 \\
(1, \text { Alk. bas. })\end{array}$ & & $\begin{array}{c}\text { P80 to } 58 \\
1440^{\circ}-1160^{\circ}\end{array}$ & $\begin{array}{l}\text { G59 to } 56 \\
1170^{\circ}-1145^{\circ}\end{array}$ & $\begin{array}{l}\text { P38-46-16 to P40-42-18 } \\
\text { P43-44-13 to P45-38-18 }\end{array}$ & & & \multicolumn{2}{|c|}{ none } \\
\hline $\begin{array}{l}\text { 433A-21-4, } 129-138 \\
(1, \text { Alk. bas. })\end{array}$ & & $\begin{array}{c}\text { P77 to } 58 \\
1374^{\circ}-1152^{\circ}\end{array}$ & $\begin{array}{l}\text { G61 to } 5 \\
1178^{\circ}-1035^{\circ}\end{array}$ & $\begin{array}{l}\text { P39-45-16 to P41-43-17 } \\
\text { P44-41-16 to P44-38-18 }\end{array}$ & $\begin{array}{l}22 \text { to } 57 \\
1140^{\circ}-900^{\circ}\end{array}$ & $\begin{array}{c}89 \\
-9 \text { to }-12\end{array}$ & \multicolumn{2}{|c|}{ none } \\
\hline $\begin{array}{l}\text { 433B-5-2, 61-68 } \\
(1, \text { Alk. bas. })\end{array}$ & & P81 to 68 & G59 to 53 & $\begin{array}{l}\mathrm{P} 40-44-16 \text { to } \mathrm{P} 41-40-19 \\
\mathrm{P} 44-40-16 \text { to } \mathrm{P} 45-38-17\end{array}$ & $\begin{array}{l}21 \text { to } 41 \\
1000^{\circ}-870^{\circ}\end{array}$ & $\begin{array}{l}93 \text { to } 95 \\
-12 \text { to }-14\end{array}$ & \multicolumn{2}{|c|}{ none } \\
\hline $\begin{array}{l}433 \mathrm{~B}-5-3,85-90 \\
(2, \text { Alk. bas. })\end{array}$ & & \multicolumn{2}{|c|}{$\begin{array}{c}\mathrm{P} 79 \text { to } 63 \\
1415^{\circ} \text { to } 1180^{\circ}\end{array}$} & $\begin{array}{l}\text { P41-44-15 to G38-44-18 } \\
\text { P44-42-14 to P43-39-18 }\end{array}$ & 25 to 39 & none & $0.418-0.585$ & $0.351-0.513$ \\
\hline $\begin{array}{l}433 \mathrm{C}-4-1,30-38 \\
(2, \text { Alk. bas. })\end{array}$ & $\begin{array}{c}82-63(83) \\
1280^{\circ}-1207^{\circ}\end{array}$ & \multicolumn{2}{|c|}{$\begin{array}{c}\text { P78 to } 60 \\
1406^{\circ} \text { to } 1152^{\circ}\end{array}$} & P43-46-11 to G43-37-21 & $\begin{array}{l}28 \text { to } 32 \\
1020^{\circ}-990^{\circ}\end{array}$ & $\begin{array}{r}93 \\
-11\end{array}$ & $0.386-0.661$ & $0.085-0.304$ \\
\hline $\begin{array}{l}433 \mathrm{C}-10-4,11-17 \\
(4 \mathrm{~F}, \text { Oliv. thol.) }\end{array}$ & & \multicolumn{2}{|c|}{$\begin{array}{c}\mathrm{G} 63 \text { to } 29 \\
1110^{\circ} \text { to } 940^{\circ}\end{array}$} & & 7 to 73 & none & $0.555-0.628$ & $0.365-0.515$ \\
\hline $\begin{array}{l}433 \mathrm{C}-12-3,57-65 \\
(9, \text { Thol.) }\end{array}$ & & $\begin{array}{l}\text { P69 to } 66 \\
1210^{\circ} \mathrm{t}\end{array}$ & $\begin{array}{l}\mathrm{G} 65 \text { to } 60 \\
1122^{\circ}\end{array}$ & P44-45-11 to G36-40-24 & 27 to 62 & none & \multicolumn{2}{|c|}{ none } \\
\hline $\begin{array}{l}433 \mathrm{C}-13-2,55-66 \\
\text { (10, Plag. thol.) }\end{array}$ & & $\begin{array}{l}\text { P69 to } 63 \\
1183^{\circ} \mathrm{t}\end{array}$ & $\begin{array}{l}\mathrm{G} 49 \text { to } 31 \\
968^{\circ}\end{array}$ & P38-51-10 to G35-35-30 & $\begin{array}{l}18 \text { to } 25 \\
1055^{\circ}-930^{\circ}\end{array}$ & $\begin{array}{c}94 \text { to } 95 \\
-11 \text { to }-13\end{array}$ & \multicolumn{2}{|c|}{ none } \\
\hline $\begin{array}{l}433 \mathrm{C}-14-3,8-15 \\
(11 \mathrm{~B}, \text { Plag. thol.) }\end{array}$ & & $\begin{array}{l}\text { P76 to } 64 \\
1310^{\circ}-1185^{\circ}\end{array}$ & $\begin{array}{c}\mathrm{G} 55 \text { to } 43 \\
1095^{\circ}-1030^{\circ}\end{array}$ & P38-49-12 to $G 30-43-27$ & $\begin{array}{l}11 \text { to } 34 \\
1060^{\circ}-900^{\circ}\end{array}$ & $\begin{array}{l}95 \text { to } 98 \\
-10 \text { to }-13\end{array}$ & \multicolumn{2}{|c|}{ none } \\
\hline $\begin{array}{l}433 C-15-6,16-31 \\
(13, \text { Thol.) }\end{array}$ & & $\begin{array}{l}\text { P84 to } 58 \\
1495^{\circ}\end{array}$ & G56 to 12 & P42-47-11 to G35-44-21 & $\begin{array}{l}19 \text { to } 36 \\
950^{\circ}-810^{\circ}\end{array}$ & $\begin{array}{c}96 \\
-13 \text { to }-15\end{array}$ & \multicolumn{2}{|c|}{ none } \\
\hline $\begin{array}{l}433 C-19-5,57-65 \\
(15 A, \text { Thol.) }\end{array}$ & & $\begin{array}{l}\text { P80 to } 65 \\
1344^{\circ}-1\end{array}$ & $\begin{array}{l}\mathrm{G} 55 \text { to } 22 \\
156^{\circ}\end{array}$ & P39-49-12 to G24-32-44 & $\begin{array}{l}26 \text { to } 33 \\
970^{\circ}-730^{\circ}\end{array}$ & $\begin{array}{l}94 \text { to } 97 \\
-12 \text { to }-17\end{array}$ & \multicolumn{2}{|c|}{ none } \\
\hline $\begin{array}{l}433 \mathrm{C}-21-4,7-13 \\
(17, \text { Thol.) }\end{array}$ & & & & & $\begin{array}{c}46 \\
970^{\circ}\end{array}$ & $\begin{array}{l}89 \text { to } 90 \\
-11\end{array}$ & \multicolumn{2}{|c|}{ none } \\
\hline $\begin{array}{l}433 \mathrm{C}-22-5,45-52 \\
(18, \text { Plag. thol.) }\end{array}$ & & $\begin{array}{l}\text { P76 to } 65 \\
1320^{\circ}-1180^{\circ}\end{array}$ & $\begin{array}{l}\mathrm{G} 63 \text { to } 31 \\
1170^{\circ}-990^{\circ}\end{array}$ & & $\begin{array}{c}5 \text { to } 40 \\
1000^{\circ}-880^{\circ}\end{array}$ & $\begin{array}{c}93 \text { to } 92 \\
-12 \text { to }-13\end{array}$ & $0.475-0.689$ & $0.056-0.124$ \\
\hline $\begin{array}{l}\text { 443C-24-7, 133-139 } \\
(19, \text { Picrite) }\end{array}$ & $86-77$ & \multicolumn{2}{|c|}{$\begin{array}{c}\text { G69 to } 45 \\
1060^{\circ} \text { to } 920^{\circ}\end{array}$} & $\begin{array}{l}\text { P7-67-26 to G10-59-31 } \\
\text { P37-51-12 to G32-50-18 }\end{array}$ & $\begin{array}{l}19 \text { to } 36 \\
1030^{\circ}-870^{\circ}\end{array}$ & $\begin{array}{c}94 \text { to } 99 \\
-11 \text { to }-15\end{array}$ & $\begin{array}{r}0.557-0.725 \\
(1\end{array}$ & $\begin{array}{l}0.319-0.597 \\
\left.0^{\circ}\right)\end{array}$ \\
\hline $\begin{array}{l}433 \mathrm{C}-28-2,73-80 \\
(25, \text { Plag. thol.) }\end{array}$ & & \multicolumn{2}{|c|}{$\begin{array}{c}\text { P79 to } 52 \\
1376^{\circ} \text { to } 1086^{\circ}\end{array}$} & $\mathrm{P} 41-48-11$ to $\mathrm{G} 33-34-24$ & $\begin{array}{l}24 \text { to } 48 \\
1060^{\circ}-800^{\circ}\end{array}$ & $\begin{array}{c}91 \text { to } 94 \\
-10 \text { to }-15\end{array}$ & \multicolumn{2}{|c|}{ none } \\
\hline $\begin{array}{l}433 \mathrm{C}-29-1,112-123 \\
\text { (26A, Picrite) }\end{array}$ & & & & & none & 91 to 100 & & \\
\hline $\begin{array}{l}433 \mathrm{C}-29-2,94-100 \\
\text { (26B, Oliv. thol.) }\end{array}$ & & & & & $\begin{array}{c}19 \text { to } 39 \\
1095^{\circ}-890^{\circ}\end{array}$ & $\begin{array}{l}92 \text { to } 97 \\
-10 \text { to }-14\end{array}$ & $0.587-0.626$ & $0.230-0.291$ \\
\hline $\begin{array}{l}433 \mathrm{C}-31-1,28-34 \\
\text { (27, Pl-Ol thol.) }\end{array}$ & $\begin{array}{c}79-66(79) \\
1168^{\circ}\end{array}$ & $\begin{array}{l}\text { P76 to } 57 \\
1300^{\circ}-1105^{\circ}\end{array}$ & $\begin{array}{l}\text { G5 } 8 \text { to } 33 \\
1105^{\circ}-1000^{\circ}\end{array}$ & G43-41-16 to G41-38-21 & $\begin{array}{l}33 \text { to } 46 \\
1000^{\circ}-850^{\circ}\end{array}$ & $\begin{array}{c}92 \text { to } 94 \\
-11 \text { to }-14\end{array}$ & \multicolumn{2}{|c|}{$0.5622_{\left(1000^{\circ}\right)^{0.211}}$} \\
\hline $\begin{array}{l}\text { 433C-34-2, 103-111 } \\
\text { (33, Oliv. thol.) }\end{array}$ & & $\begin{array}{l}\text { P74 to } 52 \\
1220^{\circ}-1030^{\circ}\end{array}$ & $\begin{array}{c}\mathrm{G} 49 \\
1010^{\circ}\end{array}$ & $\mathrm{G} 42-46-12$ to $\mathrm{G} 37-37-26$ & 36 & 96 to 98 & $0.537-0.632$ & $0.114-0.436$ \\
\hline $\begin{array}{l}433 \mathrm{C}-34-7,114-121 \\
\text { (35, Oliv. thol.) }\end{array}$ & & & & & $\begin{array}{l}37 \text { to } 77 \\
985^{\circ}-795^{\circ}\end{array}$ & $\begin{array}{l}85 \text { to } 91 \\
-9 \text { to }-13\end{array}$ & $0.553-0.706$ & $0.178-0.430$ \\
\hline $\begin{array}{l}433 \mathrm{C}-37-3,79-87 \\
(44, \text { Thol.) }\end{array}$ & & \multicolumn{2}{|c|}{$\begin{array}{r}\text { P67 to } \mathrm{G} 36 \\
1160^{\circ} \text { to } 970^{\circ}\end{array}$} & $\begin{array}{l}\text { P39-50-11 to G25-31-44 } \\
\text { G14-54-32 to G15-40-45 }\end{array}$ & $\begin{array}{c}24 \text { to } 31 \\
1030^{\circ}-960^{\circ}\end{array}$ & $\begin{array}{l}92 \text { to } 93 \\
-11 \text { to }-12\end{array}$ & $0.570-0.644$ & $0.242-0.416$ \\
\hline $\begin{array}{l}433 \mathrm{C}-38-1,67-76 \\
\text { (45B, Oliv. thol.) }\end{array}$ & $\begin{array}{c}87-78(86) \\
1260^{\circ}\end{array}$ & \multicolumn{2}{|c|}{$\begin{array}{c}\mathrm{G} 66 \text { to } 45 \\
1135^{\circ} \text { to } 1005^{\circ}\end{array}$} & G41-45-14 to G35-42-23 & none & 90 to 98 & \multicolumn{2}{|c|}{$\left(1100^{\circ}\right)$} \\
\hline $\begin{array}{l}433 \mathrm{C}-39-5,87-94 \\
(48, \text { Oliv. thol. })\end{array}$ & & & & & & 79 to 97 & $0.584-0.783$ & $0.140-0.514$ \\
\hline $\begin{array}{l}433 \mathrm{C}-40-2,88-96 \\
\text { (49, Oliv, thol.) }\end{array}$ & & & & & 99 & 79 to 90 & $0.642-0.743$ & $0.294-0.359$ \\
\hline $\begin{array}{l}433 \mathrm{C}-42-1,56-63 \\
(52, \text { Thol.) }\end{array}$ & & & & & $\begin{array}{l}36 \text { to } 86 \\
965^{\circ}-685^{\circ}\end{array}$ & $\begin{array}{c}92 \text { to } 98 \\
-12 \text { to }-14\end{array}$ & & \\
\hline $\begin{array}{l}433 C-42-3,11-20 \\
(53, \text { Picrite) }\end{array}$ & & $\begin{array}{l}\text { P79 to } 54 \\
1330^{\circ}-1\end{array}$ & $090^{\circ}$ & P41-49-10 to G $33-35-32$ & $\begin{array}{l}25 \text { to } 31 \\
1010^{\circ}-970^{\circ}\end{array}$ & $\begin{array}{c}93 \text { to } 99 \\
-11 \text { to }-12\end{array}$ & \multicolumn{2}{|c|}{ none } \\
\hline $\begin{array}{l}433 \mathrm{C}-42-5,85-92 \\
(54, \text { Picrite) }\end{array}$ & & & & & $\begin{array}{c}20 \text { to } 46 \\
1020^{\circ}-845^{\circ}\end{array}$ & $\begin{array}{l}91 \text { to } 95 \\
-11 \text { to }-14\end{array}$ & 0.642 & 0.359 \\
\hline $\begin{array}{l}443 C-47-5,92-100 \\
(64, \text { Thol.) }\end{array}$ & & $\begin{array}{l}\text { P65 to } 64 \\
1175^{\circ}-1090^{\circ}\end{array}$ & $\begin{array}{c}\mathrm{G} 60 \text { to } 47 \\
1155^{\circ}-1045^{\circ}\end{array}$ & G34-49-17 to G37-43-20 & 32 to 67 & & $0.521-0.668$ & $0.324-0.371$ \\
\hline $\begin{array}{l}433 \mathrm{C}-49-2,17-24 \\
(66, \text { Thol.) }\end{array}$ & & $\begin{array}{l}\mathrm{P} 66 \text { to } 34 \\
1195^{\circ}-1030^{\circ}\end{array}$ & $\begin{array}{l}\mathrm{G} 61 \text { to } 31 \\
1040^{\circ}-980^{\circ}\end{array}$ & $P 43-41-16$ to $G 39-26-35$ & $\begin{array}{c}20 \text { to } 33 \\
1050^{\circ}-670^{\circ}\end{array}$ & $\begin{array}{l}93 \text { to } 99 \\
-11 \text { to }-15\end{array}$ & $0.470-0.810$ & $0.065-0.449$ \\
\hline
\end{tabular}

$\mathrm{b}_{\mathrm{b}}$ ) indicates calculated equilibrium olivine composition for this rock.

$\mathrm{b}_{\mathrm{P}}$ indicates Phenocryst, $\mathrm{G}$ indicates groundmass.

${ }^{\mathrm{C}} \mathrm{Cr} \#$ is $\mathrm{Cr} /(\mathrm{Cr}+\mathrm{Al}), \mathrm{Mg} \#$ is $\mathrm{Mg} /\left(\mathrm{Mg}+\mathrm{Fe}^{2+}\right)$ 
(altered to iddingsite and clays) that partially encloses chemically variable spinel $\left\{\left(\mathrm{Cr}_{4.3-0.4} \mathrm{Al}_{1.9-0.5} \mathrm{Fe}_{4.6-2.4}^{3+}\right)\right.$ $\left.\left(\mathrm{Mg}_{0.9-1.2} \mathrm{Mn}_{0.1} \mathrm{Fe}_{4.4-0.5}^{2+}\right)\left(\mathrm{Ti}_{2.6-6.3} \mathrm{Fe}_{5.2-12.6}\right) \mathrm{O}_{32}\right\}$. The groundmass consists of plagioclase $\left(\mathrm{An}_{63} \mathrm{Or}_{1}\right.$ to $\mathrm{An}_{31}$ $\mathrm{Or}_{4}$ ), clinopyroxene (not analyzed), elongate ilmenite $\left(\mathrm{Il}_{93}-\mathrm{Il}_{94} ; \mathrm{MgO}=2-3\right.$ wt. \%), equant titanomagnetite $\left(\mathrm{Mt}_{5}-\mathrm{Mt}_{40}\right)$, and rare pyrite and chalcopyrite.

\section{Sample 433C-24-7, 133-139 cm, Tholeiitic Picrite}

This sample, from the lower part of the interior of Flow Unit 19, has a porphyritic intergranular texture, and contains nearly 40 per cent olivine phenocrysts $\left(\mathrm{Fo}_{86-77}\right)$ and microphenocrysts of augite $\left(\mathrm{Wo}_{37} \mathrm{En}_{51} \mathrm{Fs}_{12}-\right.$ $\left.\mathrm{Wo}_{38} \mathrm{En}_{49} \mathrm{Fs}_{14}\right)$ and pigeonite $\left(\mathrm{Wo}_{8} \mathrm{En}_{67} \mathrm{Fs}_{25}-\mathrm{Wo}_{7} \mathrm{En}_{66}\right.$ $\left.\mathrm{Fs}_{27}\right)$. The groundmass consists of plagioclase $\left(\mathrm{An}_{69} \mathrm{Or}_{0^{-}}\right.$ $\left.\mathrm{An}_{45} \mathrm{Or}_{2}\right)$, augite $\left(\mathrm{Wo}_{36} \mathrm{En}_{48} \mathrm{Fs}_{16}-\mathrm{Wo}_{32} \mathrm{En}_{50} \mathrm{Fs}_{18}\right)$, pigeonite $\left(\mathrm{Wo}_{8} \mathrm{En}_{64} \mathrm{Fs}_{28}-\mathrm{Wo}_{10} \mathrm{En}_{59} \mathrm{Fs}_{31}\right)$, equant titanomagnetite $\left(\mathrm{Mt}_{19}-\mathrm{Mt}_{36}\right)$, ilmenite $\left(\mathrm{Il}_{94}-\mathrm{Il}_{99}\right)$, and rare pyrite. The olivine phenocrysts contain numerous euhedral to rounded chromian spinel $\left\{\left(\mathrm{Cr}_{9.2-6.8} \mathrm{Al}_{5.9-2.9} \mathrm{Fe}_{0.9-2.4}^{3+}\right)\right.$ $\left.\left(\mathrm{Mg}_{4.8-2.6} \mathrm{Mn}_{0.1-0.2} \mathrm{Fe}_{2.7-5.1}^{2+}\right)\left(\mathrm{Ti}_{0.2-2.0} \mathrm{Fe}_{0.4-4.0}^{2+}\right) \mathrm{O}_{32}\right\}$. The pigeonite microphenocrysts and groundmass have lower $\mathrm{Al}_{2} \mathrm{O}_{3}$ and $\mathrm{Na}_{2} \mathrm{O}$ contents and total "other" components, and higher $\mathrm{MnO}$ contents than the coexisting augite phenocrysts and groundmass.

\section{Sample 433C-28-2, 73-80 cm, Plagioclase Tholeiite}

This sample, from the interior of Flow Unit 25, has a pilotaxitic to intergranular texture, and contains glomerocrysts of plagioclase $\left(\mathrm{An}_{79} \mathrm{Or}_{0}-\mathrm{An}_{52} \mathrm{Or}_{1}\right)$ and clinopyroxene $\left(\mathrm{Wo}_{41} \mathrm{En}_{48} \mathrm{Fs}_{11}-\mathrm{Wo}_{37} \mathrm{En}_{46} \mathrm{Fs}_{17}\right.$; "others" = 6-19 mole \%). Plagioclase $\left(\mathrm{An}_{55} \mathrm{Or}_{1}-\mathrm{An}_{62} \mathrm{Or}_{1}\right)$ is enclosed by clinopyroxene and is the liquidus phase. The groundmass consists of plagioclase, clinopyroxene $\left(\mathrm{Wo}_{39} \mathrm{En}_{47} \mathrm{Fs}_{14}-\mathrm{Wo}_{33} \mathrm{En}_{43} \mathrm{Fs}_{24}\right.$; "others" = 6-19 mole $\%$ ), equant titanomagnetite $\left(\mathrm{Mt}_{24}-\mathrm{Mt}_{48}\right)$, and elongate ilmenite $\left(\mathrm{Il}_{91}-\mathrm{Il}_{94}\right)$.

\section{Sample 433C-29-1, 112-123 cm: Plagioclase Tholeiite}

This sample, from the lower part of the massive interior of Flow Unit 26A has 0.5- to 2-mm vesicles, an intersertal texture, and contains phenocrysts of plagioclase, clinopyroxene, and olivine that is completely altered to clays. The only phase analyzed was elongate groundmass ilmenite $\left(\mathrm{Il}_{91-100}\right)$. Pyrite is present but rare.

\section{Sample 433C-29-2, 94-100 cm: Plagioclase Tholeiite}

This sample, from the interior of Flow Unit 26B, contains rare irregular vesicles filled with clays, has a pilotaxitic to intergranular texture, and contains phenocrysts of plagioclase, clinopyroxene, and olivine. The groundmass consists of plagioclase, clinopyroxene, tiny exsolved titanomagnetite $\left(\mathrm{Mt}_{39}-\mathrm{Mt}_{19}\right)$, ilmenite $\left(\mathrm{Il}_{92}-\mathrm{Il}_{97}\right)$, and rare pyrite. The olivine phenocrysts contain euhedral chromian spinel $\left\{\left(\mathrm{Cr}_{6.5-6.0} \mathrm{Al}_{3.9-4.6} \mathrm{Fe}_{3.2-3.8}^{3+}\right)\left(\mathrm{Mg}_{2.1-2.6} \mathrm{Mn}_{0.1}\right.\right.$ $\left.\left.\mathrm{Fe}_{4.7-4.2}^{2+}\right)\left(\mathrm{Ti}_{0.8-1.1} \mathrm{Fe}_{1.6-2.2}^{2+}\right) \mathrm{O}_{32}\right\}$.

\section{Sample 433C-31-1, 28-34 cm: Plagioclase-Olivine Tholeiite}

This sample, from the bottom part of the interior of Flow Unit 27, has pilotaxitic texture, and contains phe- nocrysts of plagioclase $\left(\mathrm{An}_{76} \mathrm{Or}_{1}-\mathrm{An}_{57} \mathrm{Or}_{1}\right)$, olivine $\left(\mathrm{Fo}_{79-66}\right)$ with clay replacement along fractures and on the rims, and rare clinopyroxene. The groundmass consists of plagioclase laths $\left(\mathrm{An}_{58} \mathrm{Or}_{1}-\mathrm{An}_{33} \mathrm{Or}_{4}\right)$, clinopyroxene $\left(\mathrm{Wo}_{43} \mathrm{En}_{41} \mathrm{Fs}_{16}-\mathrm{Wo}_{41} \mathrm{En}_{38} \mathrm{Fs}_{21}\right)$, equant titanomagnetite $\left(\mathrm{Mt}_{33}-\mathrm{Mt}_{46}, \mathrm{Cr}_{2} \mathrm{O}_{3}\right.$ up to 0.2 wt. \%), rare elongate ilmenite $\left(\mathrm{Il}_{92}-\mathrm{Il}_{94} ; \mathrm{MgO}=2.3-2.9\right.$ wt. \%). Compared with other clinopyroxenes from Hawaiian tholeiitic basalts (Fodor et al., 1975), the pyroxenes in this sample are Wo-rich as well as $\mathrm{TiO}_{2}$ - and $\mathrm{Na}_{2} \mathrm{O}$-rich. The olivine phenocrysts contain chromian spinel crystals, some of which have reacted with the adjacent groundmass to form chromian titanomagnetite. The full range of compositions found is $\left\{\left(\mathrm{Cr}_{5.6-1.7} \mathrm{Al}_{5.1-0.6} \mathrm{Fe}_{3.3-5.6}^{3+}\right)\right.$ $\left.\left(\mathrm{Mg}_{3.4-1.2} \mathrm{Mn}_{0.1} \mathrm{Fe}_{4.5-2.7}^{2+}\right)\left(\mathrm{Ti}_{0.9-4.0} \mathrm{Fe}_{1.8-8.0}^{2+}\right) \mathrm{O}_{32}\right\}$.

\section{Sample 433C-34-2, 103-111 cm: Tholeiitic Picrite}

This sample, from the upper part of the interior of Flow Unit 33, has ophitic to intersertal texture, and contains phenocrysts of olivine (completely altered to clays with iddingsite on the rims), and resorbed plagioclase $\left(\mathrm{An}_{74} \mathrm{Or}_{0}-\mathrm{An}_{52} \mathrm{Or}_{2}\right)$. The groundmass consists of plagioclase $\left(\mathrm{An}_{49} \mathrm{Or}_{1}\right)$, clinopyroxene $\left(\mathrm{Wo}_{42} \mathrm{En}_{46} \mathrm{Fs}_{12}-\mathrm{Wo}_{37}\right.$ $\mathrm{En}_{37} \mathrm{Fs}_{26}$, "others" = 9-14 mole \%, $\mathrm{TiO}_{2}=0.9-1.7$ wt. $\%, \mathrm{Al}_{2} \mathrm{O}_{3}=1.9-3.6$ wt. $\%$ ), tiny equant exsolved titanomagnetite $\left(\mathrm{Mt}_{36}\right)$, and elongate ilmenite $\left(\mathrm{Il}_{96}-\mathrm{Il}_{98}\right)$. The olivine phenocrysts contain rare chromian spinel that is continuously zoned to chrome-rich titanomagnetite where it is in contact with the groundmass. The full range of compositions is $\left\{\left(\mathrm{Cr}_{7.7-2.7} \mathrm{Al}_{6.4-1.6} \mathrm{Fe}_{1.4-2.6}^{3+}\right)\right.$ $\left.\left(\mathrm{Mg}_{4.0-1.4} \mathrm{Mn}_{0.1-0.3} \mathrm{Fe}_{4.3-1.9}^{2+}\right)\left(\mathrm{Ti}_{0.3-4.6} \mathrm{Fe}_{0.6-9.2}\right)_{32}\right\}$.

\section{Sample 433C-34-7, 114-121 cm: Olivine Tholeiite}

This sample, from the upper part of the interior of Flow Unit 35, has intergranular texture, and contains phenocrysts of olivine (completely altered to iddingsite, clays, and calcite), plagioclase, and rare clinopyroxene. The only minerals analyzed were the opaque oxides. These are abundant tiny equant exsolved titanomagnetite $\left(\mathrm{Mt}_{77}-\mathrm{Mt}_{37}, \mathrm{MnO}\right.$ up to $2.5 \mathrm{wt}$. \%), elongate ilmenite $\left(\mathrm{Il}_{76}-\mathrm{Il}_{92}, \mathrm{MgO}=2.9-3.8\right.$ wt $\%$ ), and chromian spinel enclosed in the olivine pseudomorphs. The full range of analyzed chrome spinel compositions is $\left\{\left(\mathbf{C r}_{9.2-}\right.\right.$ $\left.{ }_{2.6} \mathrm{Al}_{5.0-1.7} \mathrm{Fe}_{1.5-6.1}^{3+}\right)\left(\mathrm{Mg}_{4.7-1.9} \mathrm{Mn}_{0.1-0.2} \mathrm{Fe}_{2.9-4.8}^{2+}\right)\left(\mathrm{Ti}_{0.2-2.8}\right.$ $\mathrm{Fe}_{0.4-5.6}^{2+} \mathrm{O}_{32}$ \}. Pyrite is present within the saponite to nontronite clays replacing olivine.

\section{Sample 433C-37-3, 79-87 cm: Tholeiite}

This sample, from the upper part of the interior of Flow Unit 44, has diabasic to intersertal texture, and contains olivine phenocrysts (completely altered to clays), and microphenocrysts of clinopyroxene ( $\mathrm{Wo}_{39}$ $\mathrm{En}_{50} \mathrm{Fs}_{11}-\mathrm{Wo}_{37} \mathrm{En}_{46} \mathrm{Fs}_{17}$, "others" = 7-12 mole \%, $\mathrm{Cr}_{2} \mathrm{O}_{3}$ up to 0.9 wt. $\%, \mathrm{Al}_{2} \mathrm{O}_{3}=1.9-2.8$ wt. $\%, \mathrm{TiO}_{2}=$ 0.6-1.2 wt. \%) and plagioclase $\left(\mathrm{An}_{67} \mathrm{Or}_{0}-\mathrm{An}_{36} \mathrm{Or}_{3}\right)$ that are gradational in size to the groundmass. The groundmass contains augite to sub-calcic augite $\left(\mathrm{Wo}_{38} \mathrm{En}_{50} \mathrm{Fs}_{12}\right.$ $\mathrm{Wo}_{25} \mathrm{En}_{31} \mathrm{Fs}_{44}$, "others" = 4-10 mole \%), pigeonite $\left(\mathrm{Wo}_{14} \mathrm{En}_{54} \mathrm{Fs}_{32}-\mathrm{Wo}_{15} \mathrm{En}_{40} \mathrm{Fs}_{45}\right.$, "others" = 4-6 mole \%) equant to skeletal titanomagnetite $\left(\mathrm{Mt}_{24}-\mathrm{Mt}_{31}, \mathrm{MnO}\right.$ up to $1.9 \mathrm{wt} \%$ ), and elongate ilmenite $\left(\mathrm{Il}_{92}-\mathrm{Il}_{93}\right)$. The oliv- 
ine phenocrysts contain chromian spinel crystals that have a narrow range of compositions $\left\{\left(\mathrm{Cr}_{7.7-7.4} \mathrm{Al}_{4.2-5.5}\right.\right.$ $\left.\mathrm{Fe}_{1.8-2.1}^{3+}\right)\left(\mathrm{Mg}_{3.4-2.2} \mathrm{Mn}_{0.1-0.2} \mathrm{Fe}_{4.0-4.6}^{2+}\right)\left(\mathrm{Ti}_{0.4-1.1} \mathrm{Fe}_{0.8-2.2}^{2+}\right)$ $\left.\mathrm{O}_{32}\right\}$.

\section{Sample 433C-38-1, 67-76 cm: Olivine Tholeiite}

This sample, from the upper part of the interior Flow Unit 45B, has an ophitic texture, and contains phenocrysts of olivine $\left(\mathrm{Fo}_{87-78}\right)$ altered to clays on the rims and along fractures. The groundmass is plagioclase $\left(\mathrm{An}_{66} \mathrm{Or}_{1}-\mathrm{An}_{45} \mathrm{Or}_{2}\right)$ partially altered to clays and zeolites, clinopyroxene ( $\mathrm{Wo}_{41} \mathrm{En}_{45} \mathrm{Fs}_{14}-\mathrm{Wo}_{35} \mathrm{En}_{42} \mathrm{Fs}_{23}, \mathrm{Cr}_{2} \mathrm{O}_{3}$ up to 0.7 wt. $\%, \mathrm{Al}_{2} \mathrm{O}_{3}$ up to 4 wt. $\%$, "others" = 7-17 mole \%), elongate ilmenite $\left(\mathrm{Il}_{90}-\mathrm{Il}_{98}, \mathrm{MgO}=2.5-3.8\right.$ wt. \%), and rare pyrite. The olivine phenocrysts contain chromian spinel that is zoned to chrome-rich titanomagnetite where the crystals are in contact with the groundmass. The full range of analyzed compositions is $\left\{\left(\mathrm{Cr}_{9.2-0.4} \mathrm{Al}_{5.3-1.5} \mathrm{Fe}_{1.2-3.5}^{3+}\right)\left(\mathrm{Mg}_{4.7-1.7} \mathrm{Mn}_{0.1-0.2}\right.\right.$ $\left.\mathrm{Fe}_{2.9-5.3}^{2+}\right)\left(\mathrm{Ti}_{0.2-3.5} \mathrm{Fe}_{0.4-7.0}^{+2}\right) \mathrm{O}_{32}$.

\section{Sample 433C-39-5, 87-94 cm: Olivine Tholeiite}

This sample, from the lower part of the interior of Flow Unit 48, has intergranular texture, and contains phenocrysts of olivine (mostly altered to clays) and rare plagioclase. The groundmass contains pigeonite as well as high-Ca clinopyroxene. Only the opaque oxides were analyzed. The groundmass contains elongate ilmenite $\left(\mathrm{Il}_{79}-\mathrm{Il}_{97}, \mathrm{MgO}=2.1-3.0\right.$ wt. \%) with minor exsolution. The olivine phenocrysts contain chromian spinel zoned to chrome-rich titanomagnetite where it is in contact with the groundmass. The full range of compositions is $\left\{\left(\mathrm{Cr}_{9.7-4.8} \mathrm{Al}_{5.5-1.3} \mathrm{Fe}_{1.3-3.9}^{3+}\right)\left(\mathrm{Mg}_{4.2-1.5} \mathrm{Mn}_{0.1-}\right.\right.$ $\left.\left.{ }_{0.2} \mathrm{Fe}_{3.3-5.8}^{2+}\right)\left(\mathrm{Ti}_{0.2-3.0} \mathrm{Fe}_{0.4-6.0}^{2+}\right) \mathrm{O}_{32}\right\}$.

\section{Sample 433C-40-2,88-96 cm: Olivine Tholeiite}

This sample, from the interior of Flow Unit 49, has an intergranular texture, and contains phenocrysts and microphenocrysts of olivine replaced by clays, rare plagioclase, and rare clinopyroxene. Olivine pseudomorphs contain euhedral to rounded chromain spinel similar in composition to that in Flow Unit 48, although no crystals were found that are zoned to chrome-rich titanomagnetite. The full range of composition is $\left\{\left(\mathrm{Cr}_{9.8-9.5}\right.\right.$ $\left.\mathrm{Fe}_{4.0-3.3} \mathrm{Fe}_{1.7-1.9}^{3+}\right)\left(\mathrm{Mg}_{2.8-2.4} \mathrm{Mn}_{0.2} \mathrm{Fe}_{5.1-4.2}^{2+}\right)\left(\mathrm{Ti}_{0.3-0.7}\right.$ $\left.\left.\mathrm{Fe}_{0.6-1.4}^{2+}\right) \mathrm{O}_{32}\right\}$. The groundmass contains elongate ilmenite $\left(\mathrm{Il}_{79}-\mathrm{Il}_{90}\right)$ that is mottled as a result of a combination of secondary oxidation and exsolution; rare nearly pure magnetite $\left(\mathrm{Mt}_{99}\right)$, probably of secondary origin; and rare pyrite and calcopyrite.

\section{Sample 433C-42-1, 56-63 cm: Tholeiite}

This sample, from the massive interior of Flow Unit 52 , has an intersertal texture, and contains rare phenocrysts of plagioclase, clinopyroxene, and olivine (completely replaced by clays and iddingsite). Only the opaque oxides were analyzed. The groundmass contains equant, exsolved, titanomagnetite $\left(\mathrm{Mt}_{86}-\mathrm{Mt}_{35}, \mathrm{Cr}_{2} \mathrm{O}_{3}\right.$ up to 0.2 wt. \%), elongate ilmenite $\left(\mathrm{Il}_{92}-\mathrm{Il}_{98}\right)$, and rare pyrite.

\section{Sample 433C-42-3, 11-20 cm: Plagioclase Tholeiite}

This sample, from the lower part of the massive interior of Flow Unit 53, has an intersertal texture, rare clay-filled vesicles, and contains glomerocrysts of plagioclase $\left(\mathrm{An}_{79} \mathrm{Or}_{0}-\mathrm{An}_{54} \mathrm{Or}_{2}\right)$, clinopyroxene $\left(\mathrm{Wo}_{41} \mathrm{En}_{49}\right.$ $\mathrm{Fs}_{10}-\mathrm{Wo}_{35} \mathrm{En}_{50} \mathrm{Fs}_{15}, \mathrm{Cr}_{2} \mathrm{O}_{3}=0.4-1.1$ wt.\% , "others" $=5-16$ mole $\%)$, and olivine that is completely altered to clays. The groundmass contains plagioclase $\left(\mathrm{An}_{64} \mathrm{Or}_{1}\right)$, clinopyroxene $\left(\mathrm{Wo}_{39} \mathrm{En}_{48} \mathrm{Fs}_{13}-\mathrm{Wo}_{33} \mathrm{En}_{35} \mathrm{Fs}_{32}\right.$ ), skeletal titanomagnetite $\left(\mathrm{Mt}_{25}-\mathrm{Mt}_{31}\right)$, elongate ilmenite $\left(\mathrm{Il}_{93}-\right.$ $\left.\mathrm{Il}_{99}\right)$, and rare pyrite. Some of the plagioclase occurs as xenocrysts that have cores $\left(\mathrm{An}_{64} \mathrm{Or}_{1}-\mathrm{An}_{62} \mathrm{Or}_{1}\right)$ and rims $\left(\mathrm{An}_{67} \mathrm{Or}_{0}-\mathrm{An}_{57} \mathrm{Or}_{1}\right)$.

\section{Sample 433C-42-5, 85-92 cm: Plagioclase Tholeiite}

This sample, from the massive interior of Flow Unit 54, has an intersertal texture, and contains glomerocrysts of plagioclase, rare clinopyroxene, and rare olivine that is completely altered to clays and iddingsite. The only minerals analyzed were the opaque oxides. The groundmass contains equant exsolved titanomagnetite $\left(\mathrm{Mt}_{46}-\mathrm{Mt}_{20}, \mathrm{MnO}\right.$ up to $1.3 \mathrm{wt}$. \%) and elongate ilmenite $\left(\mathrm{Il}_{91}-\mathrm{Il}_{96}, \mathrm{Cr}_{2} \mathrm{O}_{3}\right.$ up to 0.4 wt. \%). A single chromian spinel enclosed in olivine was analyzed $\left\{\left(\mathrm{Cr}_{7.9} \mathrm{Al}_{4.4}\right.\right.$ $\left.\left.\mathrm{Fe}_{2.8}^{3+}\right)\left(\mathrm{Mg}_{3.0} \mathrm{Mn}_{0.2} \mathrm{Fe}_{4.5}^{2+}\right)\left(\mathrm{Ti}_{0.4} \mathrm{Fe}_{0.8}^{2+}\right) \mathrm{O}_{32}\right\}$.

\section{Sample 433C-47-5, 92-100 cm: Tholeiite}

This sample, from the upper part of the massive interior of Flow Unit 64, has a hyalopilitic texture, and contains sparse microphenocrysts of plagioclase $\left(A n_{65}\right.$ $\mathrm{Or}_{1}-\mathrm{An}_{47} \mathrm{Or}_{2}$ ), olivine altered to iddingsite, tiny clinoiddingsite. The groundmass contains plagioclase $\left(\mathrm{An}_{60}\right.$ $\mathrm{Or}_{1}-\mathrm{An}_{47} \mathrm{Or}_{2}$ ), olivine altered to iddingsite, tiny clinopyroxene grains $\left(\mathrm{Wo}_{34} \mathrm{En}_{49} \mathrm{Fs}_{17}-\mathrm{Wo}_{37} \mathrm{En}_{43} \mathrm{Fs}_{20}\right.$, "others" $=8$ to 14 mole $\%$ ), and tiny equant exsolved titanomagnetite $\left(\mathrm{Mt}_{32}-\mathrm{Mt}_{67}, \mathrm{MgO}=3.2-5.4\right.$ wt. \%), and rare pyrite. The rare olivine pseudomorphs contain chromian spinel $\left\{\left(\mathrm{Cr}_{6.3-5.8} \mathrm{Al}_{3.2-5.8} \mathrm{Fe}_{4.9-3.5}^{3+}\right)\left(\mathrm{Mg}_{3.1-2.8} \mathrm{Mn}_{0.2}\right.\right.$ $\left.\left.\mathrm{Fe}_{4.2-4.1}^{2+}\right)\left(\mathrm{Ti}_{0.6-0.8} \mathrm{Fe}_{1.2-1.6}^{2+}\right) \mathrm{O}_{32}\right\}$. Pyrite is present but rare. This sample was originally designated an alkalic basalt on the basis of shipboard chemical analysis and the presence of olivine in the groundmass. We have reclassified it according to the mineral compositions, trace-element abundances (see Clague and Frey, this volume), and the presence of secondary phillipsite that shifts the whole-rock composition toward alkalic basalt (see Kirkpatrick et al., this volume).

\section{Sample 433C-49-2, 17-24 cm: Tholeiite}

This sample, from the massive interior of Flow Unit 66 (the bottom flow recovered), has an intersertal texture, and contains rare phenocrysts of plagioclase $\left(\mathrm{An}_{66}\right.$ $\left.\mathrm{Or}_{1}-\mathrm{An}_{34} \mathrm{Or}_{3}\right)$, clinopyroxene $\left(\mathrm{Wo}_{43} \mathrm{En}_{41} \mathrm{Fs}_{16}-\mathrm{Wo}_{40}\right.$ $\mathrm{En}_{37} \mathrm{Fs}_{23}, \mathrm{Cr}_{2} \mathrm{O}_{3}$ up to 0.4 wt \%, $\mathrm{Al}_{2} \mathrm{O}_{3}$ up to 4.4 wt. \%, "others" = 7-19 mole \%), and olivine that is altered to clays. The groundmass contains plagioclase $\left(\mathrm{An}_{61}\right.$ $\left.\mathrm{Or}_{1}-\mathrm{An}_{31} \mathrm{Or}_{4}\right)$, clinopyroxene $\left(\mathrm{Wo}_{43} \mathrm{En}_{40} \mathrm{Fs}_{17}-\mathrm{Wo}_{39}\right.$ $\mathrm{En}_{26} \mathrm{Fs}_{35}$ ), olivine altered to clays, equant titanomagnetite $\left(\mathrm{Mt}_{20}-\mathrm{Mt}_{33}, \mathrm{Cr}_{2} \mathrm{O}_{3}\right.$ up to 2.4 wt. \%), and elongate ilmenite $\left(\mathrm{Il}_{93}-\mathrm{Il}_{99}\right)$. The olivine phenocrysts contain chromian spinel zoned to chrome-rich titanomagnetite 
rims where the chrome spinel is in contact with the groundmass. The full range of compositions is $\left\{\left(\mathrm{Cr}_{6.4-}\right.\right.$ $\left.{ }_{4.1} \mathrm{Al}_{6.4-1.1} \mathrm{Fe}_{1.7-3.8}^{3+}\right)\left(\mathrm{Mg}_{3.9-0.7} \mathrm{Mn}_{0.1-0.2} \mathrm{Fe}_{4.6-2.7}^{2+}\right)$ $\left(\mathrm{Ti}_{0.8-3.8} \mathrm{Fe}_{1.6-7.6}^{2+} \mathrm{O}_{32}\right\}$.

\section{Site 433 Tholeiitic Basalts: Summary and Interpretation}

To facilitate discussion, we have subdivided the tholeiitic basalts into three groups according to modal phenocryst abundances. The three groups are (1) olivine tholeiites containing more than 5 per cent olivine phenocrysts, (2) plagioclase tholeiites containing more than 5 per cent plagioclase phenocrysts and less than 5 per cent of either olivine or clinopyroxene phenocrysts, and (3) tholeiites containing less than 5 per cent of any pheno-cryst phase.

\section{Tholeiites with 5 Per Cent Olivine}

The mineral compositions for olivine, pyroxene, plagioclase, $\mathrm{Fe}$-Ti oxides, and chromite are shown in Figure 6. Table 11 summarizes the mineralogical data for these samples, as well as temperature estimates for olivine, plagioclase, olivine-chromite pairs, and ilmenitemagnetite pairs.

The tholeiitic basalts containing more than 5 per cent olivine include tholeiitic picrites or oceanites (containing $>15 \%$ olivine), olivine tholeiites (containing $>5 \%$, but $<15 \%$ olivine) and a single olivine-plagioclase tholeiite that contains more than 5 percent of both olivine and plagioclase. In all these samples, chromian spinel appears to be the liquidus phase; it is generally enclosed within olivine that is about $\mathrm{Fo}_{87-86}$, and is zoned to $\mathrm{Fo}_{78-77}$. The olivine-plagioclase tholeiite (Sample 433C-31-1, 28-34 cm) contains less magnesian olivine $\left(\mathrm{Fo}_{79-66}\right)$, and the enclosed chromian spinels is more titaniferous and less magnesian than spinels in the olivine tholeiites and oceanites. The equilibrium olivine compositions (noted $\mathrm{n}$ parentheses in Table 11) were estimated assuming a $\mathrm{K}_{\mathrm{D}}=0.3$ (Roeder and Emslie, 1970), and $\mathrm{Fe}^{3+} /\left(\mathrm{Fe}^{3+}+\mathrm{Fe}^{2+}\right)=0.1$ (atomic). The olivine crystallization temperatures (Table 11) were calculated using the geothermometer of Fisk et al. (1978) and assuming that the equilibrium olivine crystallized from a magma of the same composition as the whole rock (from Kirkpatrick et al., this volume). In olivine tholeiite Sample 433C-38-1, 67-76 cm, the equilibrium oliving $\mathrm{Fo}_{86}$ compositions crystallized at about $1260^{\circ} \mathrm{C}$. The picritic tholeiite (Sample 433C-24-7, 133-139 cm), contains 22 per cent cumulate olivine $\left(\mathrm{Fo}_{86}\right)$, and no reliable crystallization temperature can be calculated for the olivine in this rock. In the olivine-plagioclase tholeiite (Sample 433C-31-1, 28-34 cm), olivine $\left(\mathrm{Fo}_{79}\right)$ crystallized at $1168^{\circ} \mathrm{C}$. Olivine-chrome spinel temperature estimates are based on the analysis of Evans and Frost (1975), with an additional $1000^{\circ} \mathrm{C}$ isotherm from the harzburgite tectonite at Thetford Mines, Quebec (Clague, unpublished data), in which clinopyroxene-orthopyroxene pairs coexist with the olivine-chromite pairs. This geothermometer indicates that the equilibration temperature of olivine-chromite from the picritic tholeiite and the olivine tholeiite is about $1100^{\circ} \mathrm{C}$; the olivine-plagioclase tholeiite yields a temperature of about $1000^{\circ} \mathrm{C}$. These low temperatures and the chrome spinel compositions suggest that the spinel has been altered even where it is enclosed in olivine.

The chromian spinel in the olivine-bearing basalts is similar to that from Kilauea tholeiites (Evans and Wright, 1972). Most of these samples contain some chromian spinel that is not completely enclosed by olivine. These spinels show dramatic zoning to chrome-rich titanomagnetite, similar to that described by Evans and Wright (1972) for the tholeiitic lavas of Kilauea Iki and Makaopuhi, by Beeson (1976) for transitional to alkalic lavas from East Molokai, and by Ridley (1977) for transitional basalts from Rhum. The zoning between chromite and titanomagnetite most probably results from reaction of the chromite with the magma at temperatures well below the original chromite crystallization temperatures.

The plagioclase phenocryst cores in Sample $433 \mathrm{C}-$ $31-1,28-34 \mathrm{~cm}$ indicate temperatures of $1300^{\circ} \mathrm{C}$, on the basis of the Na-exchange reaction of Drake (1976), when it is assumed that they crystallized from a magma having the same composition as the whole rock. These high crystallization temperatures of the plagioclase cores probably indicate that they crystallized from a magma different in composition from the present whole rock, or that they crystallized at high pressure. The plagioclase phenocryst rims appear to have crystallized after olivine at temperatures as low as $1105^{\circ} \mathrm{C}$.

Groundmass phases in the olivine-bearing tholeiitic basalts include clinopyroxene low in $\mathrm{Ca}\left(\mathrm{Wo}_{30-32}\right.$ is the lowest in each sample) and generally quite variable in composition. This variability is due mainly to substitution of $\mathrm{Fe}$ for $\mathrm{Mg}$; many of the groundmass crystals are notably Fs-rich. In general the groundmass pyroxenes are low in total "other" components. One sample (433C-24-7, 133-139 cm) contains pigeonite $\left(\mathrm{Wo}_{7} \mathrm{En}_{67}\right.$ $\mathrm{Fs}_{26}$ to $\mathrm{Wo}_{10} \mathrm{En}_{59} \mathrm{Fs}_{31}$ ) both as microphenocrysts and as groundmass crystals. The groundmass plagioclase is variable, but the more calcic crystals are generally $\mathrm{An}_{69-}$ $\mathrm{An}_{63}$, except in the sample containing abundant plagioclase phenocrysts in which it is less calcic $\left(A_{58}\right)$. The most sodic groundmass plagioclase is generally $\left(\mathrm{An}_{52} \mathrm{Or}_{2}-\mathrm{An}_{24} \mathrm{Or}_{6}\right)$. The groundmass plagioclase crystallized between about $1135^{\circ} \mathrm{C}$ and $930^{\circ} \mathrm{C}$. Most of the samples contain both ilmenite andd titanomagnetite, although Sample $433 \mathrm{C}-10-4,11-17 \mathrm{~cm}$ contains only titanomagnetite, and Samples 433C-38-1, 67-76 cm, 433C-39-5, 87-94 cm, and 433C-40-2, 88-96 cm contain only ilmenite. The titanomagnetite-ilmenite pairs equilibrated at temperatures ranging from $1030^{\circ} \mathrm{C}$ to $850^{\circ} \mathrm{C}$, under oxygen fugacities of $10^{-11}$ to $10^{-15}$ atmospheres (Lindsley and Rumble, 1977).

\section{Tholeiites with 5 Per Cent Plagioclase}

The mineral compositions for pyroxene, plagioclase, $\mathrm{Fe}-\mathrm{Ti}$ oxides, and chromite are shown in Figure 7. Table 11 summarizes the mineralogic data for these samples, as well as temperature estimates for plagioclase and for ilmenite-magnetite pairs.

All the plagioclase tholeiites contain, in addition to plagioclase, phenocrysts of clinopyroxene and altered 
olivine, except Sample 433C-28-2, 73-80 cm, which contains only plagioclase and clinopyroxene phenocrysts, and Sample 433C-22-5, 45-52 cm, which contains only plagioclase and olivine phenocrysts. In all these samples it appears that plagioclase is the (high pressure?) liquidus mineral or is xenocrystic, since its calculated crystallization temperature is over $1300^{\circ} \mathrm{C}$. The olivine is all altered now, but several samples contain chromite that is enclosed in olivine pseudomorphs. These chromite crystals contain less $\mathrm{Cr}_{2} \mathrm{O}_{3}$ and more $\mathrm{TiO}_{2}$ than those enclosed in olivine in the olivine tholeiites. The phenocrysts of clinopyroxene are generally Fs-poor, and have moderate Wo content ( $\mathrm{Wo}_{38} \mathrm{En}_{31} \mathrm{Fs}_{10}$ to $\left.\mathrm{Wo}_{40} \mathrm{En}_{46} \mathrm{Fs}_{14}\right)$. The clinopyroxene phenocrysts crystallized after the plagioclase phenocrysts (xenocrysts) in Sample 433C$28-2,73-80 \mathrm{~cm}$, and presumably did so in the other plagioclase tholeiites as well. The groundmass consists of plagioclase laths ranging in composition from $\mathrm{An}_{64}$ to $\mathrm{An}_{31}$. The groundmass plagioclase crystallized at temperatures of 1170 to $968^{\circ} \mathrm{C}$, and overlap with the temperatures at which the plagioclase phenocryst rims crystallized. Both ilmenite and titanomagnetite are present in all samples except 433C-20-1, 112-123 cm, which contains only ilmenite. The coexisting ilmenite-titanomagnetite pairs equilibrated to temperatures of $1060^{\circ} \mathrm{C}$ to $800^{\circ} \mathrm{C}$; the opaque oxides were crystallizing simultaneously with the groundmass plagioclase. The groundmass clinopyroxene is generally low in Wo content, and has a large range of Fs within each rock. The low Wo content and wide range of Fs are identical to characteristics of clinopyroxene in tholeiite basalts from Maui (Fodor et al., 1975).

Sample 433C-42-3, 11-20 cm has reverse - zoned plagioclase phenocrysts with cores of $\mathrm{An}_{58}$ and rims of $\mathrm{An}_{67}$. A zone of glass inclusions separates the $\mathrm{An}_{58}$ core from the rim, and may represent a zone of reaction of the core with the magma before crystallization of the rim. The phenocrysts have a texture similar to those in Flow Units 1 and 2 at Hole 432A, and the cores may be remnants of xenocrysts.

\section{Tholeiites}

The mineral compositions for pyroxene, plagioclase, Fe-Ti oxides, and chromite are shown in Figure 8. Table 11 summarizes the mineralogic data for these samples, as well as the temperature estimates for plagioclase and coexisting ilmenite-magnetite pairs. Each of the analyzed tholeiitic basalts contains sparse phenocrysts of plagioclase, clinopyroxene, and olivine that is completely altered, except Samples 433C-21-4, 7-13 cm and 433C-47-5, 92-100 cm, which do not contain clinopyroxene. The cores of the plagioclase phenocrysts in Samples 433C-15-6, 16-31 cm and 433C-19-5, 57-65 cm are $\mathrm{An}_{84}$ and $\mathrm{An}_{80}$, respectively. The plagioclase cores are calculated to have crystallized at temperatures over $1300^{\circ} \mathrm{C}$, and must be either xenocrysts or high-pressure phenocrysts. The plagioclase phenocrysts continued to crystallize down to temperatures of about 1156 to $1125^{\circ} \mathrm{C}$. The clinopyroxene phenocrysts generally have low Fs and moderate Wo contents; they range in com-

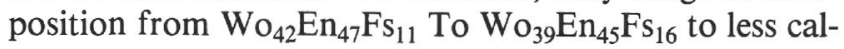

cic, more iron-rich rims. Rare chromite found enclosed in the few olivine phenocrysts is generally rather $\mathrm{Cr}$ poor and Ti-rich, even where totally enclosed in olivine. Samples 433C-37-3, 79-87 cm; 433C-47-5, 92-100 cm; and $433 \mathrm{C}-49-2,17-24 \mathrm{~cm}$ all contain plagioclase phenocrysts that began to crystallize at temperatures between $1195^{\circ}$ and $1160^{\circ} \mathrm{C}$ and continued to crystallize to temperatures as low as $1030^{\circ} \mathrm{C}$.

The groundmass plagioclase crystallized in the temperature range $1155^{\circ}$ to $970^{\circ} \mathrm{C}$, and therefore was crystallizing at the same time as the rims on the plagioclase phenocrysts. The groundmass pyroxene generally has a low Wo content, and shows a wide range of iron contents. The least calcic pyroxenes are $\mathrm{Wo}_{24}-\mathrm{Wo}_{39}$ in the six samples where clinopyroxene was analyzed. In addition, Sample 433C-37-3, 79-87 cm contains pigeonite with Wo content as low as 14 per cent. Most of the samples have groundmass pyroxene that is strongly zoned to iron-rich compositions; the most Fs-rich grains have 21 to 45 per cent. All the samples contain both ilmenite and titanomagnetite, except for Samples 433C-12-3, 57-65 $\mathrm{cm}$, and $433 \mathrm{C}-47-5,92-100 \mathrm{~cm}$, which contain only titanomagnetite. Application of the Buddington and Lindsley (1964) geothermometer indicates equilibration at temperatures of from $1050^{\circ} \mathrm{C}$ to as low as $670^{\circ} \mathrm{C}$.

\section{MINERAL CHEMISTRY}

\section{Olivine}

All the olivine analyzed in this study is present as phenocrysts and microphenocrysts in volcanic rocks. The range of compositions encountered is $\mathrm{FO}_{87-50}$. All the olivine crystals contain trace amounts of $\mathrm{CaO}(0.2$ to $0.5 \%)$, $\mathrm{MnO}(0$ to $0.8 \%)$, and $\mathrm{NiO}(0.25 \%$ in the more magnesian olivines). Figure 9 shows the relationship between $\mathrm{MnO}$ and $\mathrm{MgO}$ in all the analyzed grains. There is no apparent difference between the $\mathrm{MnO}$ contents of of olivine, at the same $\mathrm{MgO}$, from alkalic and tholeiitic basalts. The alkalic basalts and hawaiites $\left(\mathrm{Fo}_{85}-\mathrm{Fo}_{50}\right)$ contain less magnesian, higher $\mathrm{MnO}$ olivine that the tholeiitic basalts $\left(\mathrm{Fo}_{87}-\mathrm{Fo}_{66}\right)$, but this reflects the more differentiated nature of the alkalic basalts rather than any difference between alkalic and tholeiitic basalts. Very few of the analyzed flows contain fresh olivine. Most contain saponite pseudomorphs after olivine that have iddingsite (orange) rims. Flow Unit 2 at Site 433 contains olivine xenocrysts with kink bands (Figure 10e).

\section{Felspar}

The feldspar present in these flows ranges from bytownite $\left(\mathrm{An}_{84}\right)$ to sanidine. All feldspar analyses from both basalt suites are plotted in the feldspar ternary diagram (Figure 11a, 11b), where a slight but significant difference in Or content is apparent. The tholeiitic basalt feldspars have systematically lower orthoclase contents compared with those in the alkalic basalts. This reflects the lower $\mathrm{K}$ content of the tholeiitic basalts. All the feldspars contain appreciable iron ( 0.1 to 0.7 cations per formula) that is probably present as $\mathrm{Fe}_{2} \mathrm{O}_{3}$ and substitutes into the octahedral site for $\mathrm{Al}_{2} \mathrm{O}_{3}$. Figure 12 shows the relationship between atomic $\mathrm{Fe}$ and per cent 


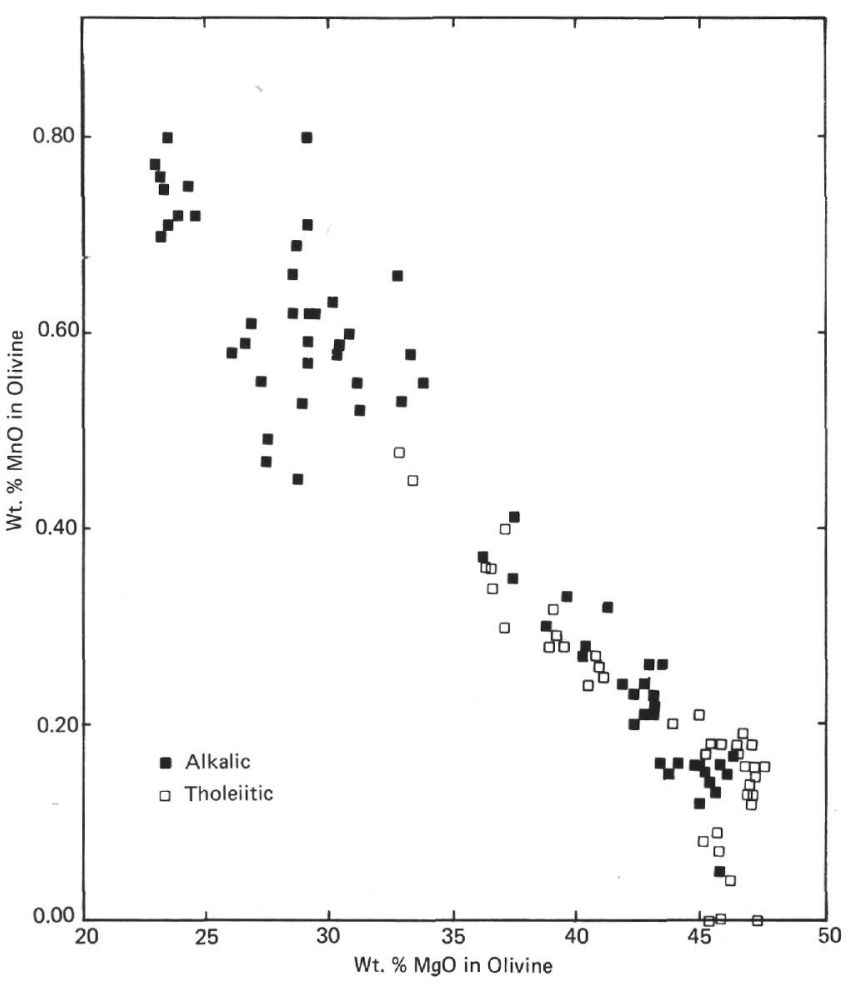

Figure 9. Variation diagram of $\mathrm{MgO}$ (wt. \%) versus $\mathrm{MnO}(w t . \%)$ in olivine in alkalic and tholeiitic basalts from all Leg 55 sites where olivine was preserved. Alkalic basalts (filled squares), tholeitic basalts (open squares).

anorthite for all the analyzed feldspars, including phenocrysts and groundmass crystals. It appears that $\mathrm{Fe}$ increases with decreasing An until about $\mathrm{An}_{40}$. As An content continues to decrease, $\mathrm{Fe}$ also decreases. There are no significant differences in Fe content between feldspars from alkalic and tholeiitic basalts.

\section{Pyroxene}

All the analyzed phenocrysts and groundmass crystals of pyroxene are clinopyroxenes. Tholeiitic Samples 433C24-7, 133-139 cm and 433C-37-3, 79-87 cm contain pigeonite (Wo $<15 \%$ ), but the rest of the tholeiitic and all the alkaline basalts contain augite to subcalcic augite. Figures $13 \mathrm{~b}$ through $13 \mathrm{~d}$ show the fields enclosing the pyroxene compositions for the tholeitic and alkalic basalts for each site, and for comparison, the fields for tholeiitic, alkalic, and nephelinic lavas from Maui (Fodor et al., 1975) and Niihau, (Clague, unpublished data)(Figure 13a). Despite the considerable overlap between these fields, it is possible to identify which eruptive suites the drill flows represent. This identification is based on per cent Wo, the extent of fractionation within a single sample, and the compositional trent (i.e., does Wo increase or decrease as Fs increases?) of the analyzed crystals. A ternary plot (Figure 14) of the "other" components $\mathrm{Ti}, \mathrm{Al}^{\mathrm{IV}}$, and $\mathrm{NaM}_{2}$ (Papike et al., 1974) shows that the pyroxenes in the tholeiitic and in the alkalic basalts are the same, except that the Hole 432A alkalic basalts have higher $\mathrm{Ti}$ and $\mathrm{Na}$ contents in $\mathrm{M}_{2}$ com- ponents. In general, the phenocrysts in both the alkalic and tholeiitic basalts are higher in $\mathrm{Cr}_{2} \mathrm{O}_{3}$ concentrations and per cent En and lower in $\mathrm{TiO}_{2}, \mathrm{Al}_{2} \mathrm{O}_{3}, \mathrm{Na}_{2} \mathrm{O}$, and $\mathrm{MnO}$ contents and per cent $\mathrm{Fs}$ than the coexisting groundmass. In both the alkalic and tholeiitic basalts, the compositions of the rims of phenocrysts overlap with the groundmass compositions in the same rocks. Samples from several flows (Flow Units 1, 2, and 10, all from Site 433) contain striking sector-zoned clinopyroxene similar to that described by Wass (1973) and Leung (1974).

\section{Chrome Spinel}

Chrome spinel is present only in the samples from Suiko Seamount (Site 433). The chrome spinel in the alkalic flows has $\mathrm{Al}>\mathrm{Cr}$; the tholeiitic flows all contain chrome spinel with $\mathrm{Cr}>\mathrm{Al}$. The $\mathrm{Al}_{2} \mathrm{O}_{3}$ contents of the alkalic and tholeiitic basalts are nearly identical; this suggests that the Al content of the chrome spinel may be controlled by pressure, the chrome spinel in the alkalic flows being equilibrated at higher $\mathrm{P}$ than spinels in the tholeiites (Sigurdsson and Schilling, 1976). This Al/Cr relation is opposite that reported by Ridley (1977) for alkalic basalts and olivine tholeiites from Rhum and Muck.

The chrome spinel cores in the alkalic basalts contain significant $\mathrm{Fe}^{3+}$ (calculated according to spinel stoichiometry); those in the tholeiitic basalts generally contain far less $\mathrm{Fe}^{3+}$, perhaps reflecting a lower $\mathrm{fO}_{2}$ during early crystallization of the tholeiitic basalts. The picritic tholeiites contain chrome spinel that has higher $\mathrm{Cr} /(\mathrm{Cr}$ $+\mathrm{Al})$ and $\mathrm{Mg} /\left(\mathrm{Mg}+\mathrm{Fe}^{2+}\right)$ than spinels in the tholeiitic basalts. At the same time, $\mathrm{Fe}^{3+}$ content is higher in the chrome spinel in the tholeiitic basalts than in the picritic basalts.

Figure 15 shows the range of chrome spinel compositions.

It is clear from these diagrams that several flows, both alkalic and tholeiitic, contain chrome spinel continuously zoned to chromian titanomagnetite. In general this extreme zoning occurs only where the chrome spinnel is no longer completely enclosed in an olivine phenocryst, and represents a reaction with the groundmass. Beeson (1976) and Ridley (1977) have described similar zoning of chrome spinel in basalts from Molokai, and from Rhum and Muck, respectively. Figure 5 shows electron-beam scans for one of these zoned spinels from Flow Unit 2 at Site 433. The boundary seen in reflecting light marks a sharp transition between an aluminous core and titaniferous rim. $\mathrm{Cr}_{2} \mathrm{O}_{3}, \mathrm{FeO}$, and $\mathrm{MgO}$ are more continuously zoned across the boundary.

Chrome spinel is present in all flows having $\mathrm{MgO}>8$ per cent and in 3 of 14 flows having $\mathrm{MgO}<8$ per cent. The $\mathrm{TiO}_{2}$ content of chrome spinel, including those enclosed in olivine, is greater in the flows containing less $\mathrm{MgO}$.

We have used the Evans and Frost (1975) olivinechromite geothermometer to estimate temperatures for a number of samples. The results are shown in Figure 16. An additional isotherm is shown that is based on olivine-chromite pairs and calculated temperatures from clinopyroxene-orthopyroxene pairs for a series of 

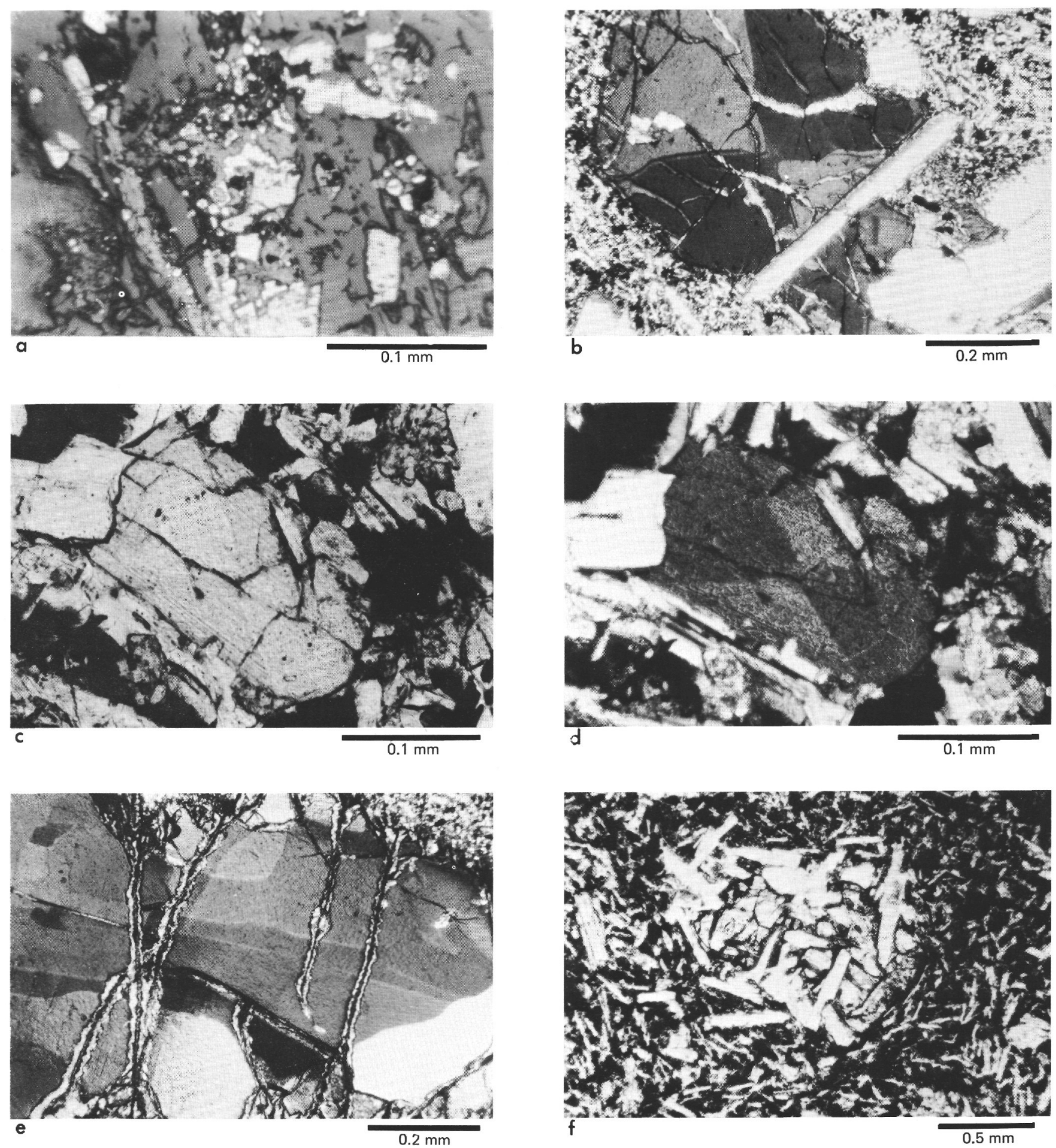

Figure 10. (a) Sample 430A-4-2, 110-118 cm. Reflecting-light photomicrograph, showing extensive pyrite replacement near the top of hawaiite Flow Unit 1. (b) Sample 433B-5-3, 85-138 cm. Crossed polarized light photomicrograph, showing large sector-zoned clinopyroxene phenocryst in the alkalic basalt that makes up Flow Unit 2 on Suiko Seamount. (c) Sample 433A-21-4, 129-138 cm. Plane polarized light photomicrograph, showing sectorzoned clinopyroxene microphenocrysts that are common in alkalic basalt Flow Unit 1 on Suiko Seamount. The pale brown sectors have higher $\mathrm{Al}_{2} \mathrm{O}_{3}, \mathrm{Na}_{2} \mathrm{O}, \mathrm{Cr}_{2} \mathrm{O}_{3}$, and $\mathrm{TiO}_{2}$ contents and lower Wo and $\mathrm{SiO}_{2}$ contents than the colorless sectors. See Figure 4 for detailed analyses of a similar crystal. (d) Same crystal as in (c), but in cross-polarized light. (e) Sample 433B-5-3, 85-90 cm. Cross-polarized light photomicrograph of kink-banded olivine xenocrysts found only in alkalic basalt Flow Unit 2 on Suiko Seamount. (f) Sample 433C-31-1, 28-34 cm. A small plagioclase-olivine inclusion in a tholeiitic basalt from Suiko Seamount. 


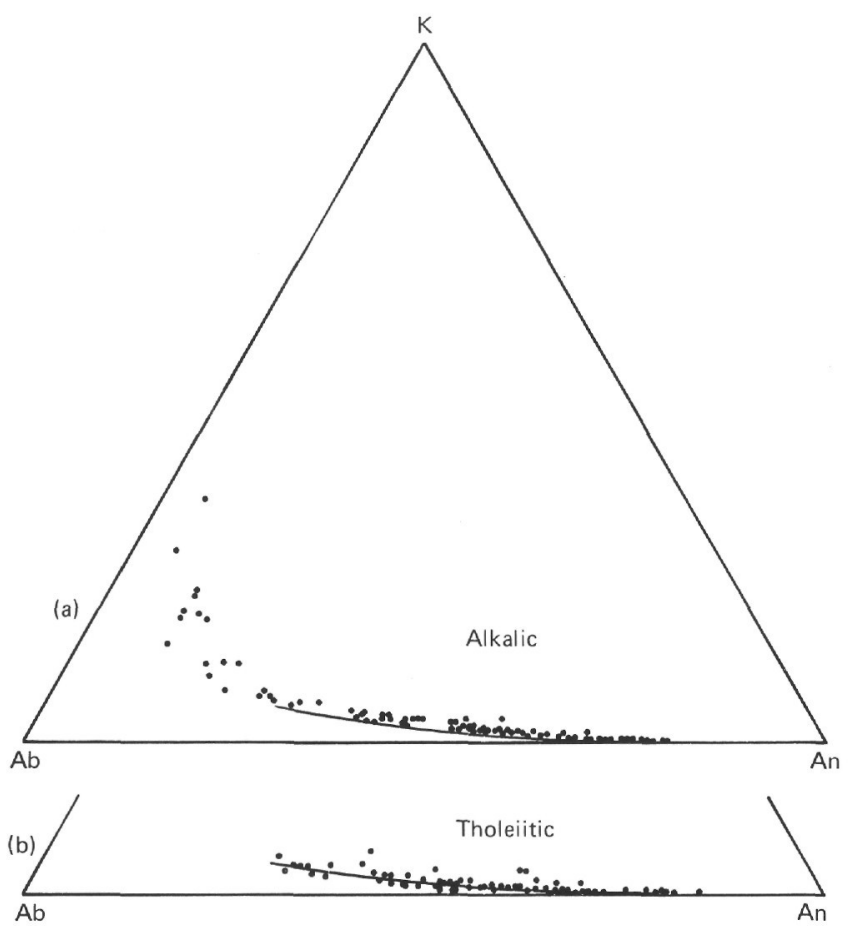

Figure 11. Variation diagram of $K$ versus anorthite mole fraction of plagioclase from all alkalic (a) and tholeiitic (b) basalt analyzed from Leg 55.

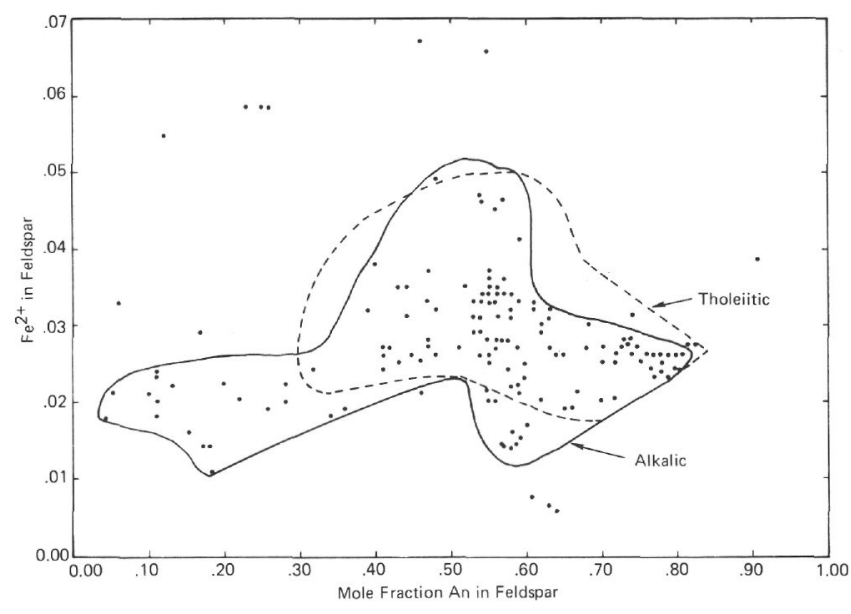

Figure 12. Variation diagram of iron as $\mathrm{Fe}^{2+}$ vs. anorthite mole fraction in plagioclase from all alkalic and tholeiitic basalts analyzed. Individual data points and fields for tholeiites and alkalic basalts are shown.

samples from the Thetford Mines ophiolite in Southern Quebec (Clague, unpublished data).

\section{Fe-Ti Oxides}

Most of the flows contain both ilmenite and titanomagnetite, except those from Site 432, which contain only titanomagnetite. In general, the titanomagnetite is partially exsolved and contains lamellae of ilmenite; the ilmenite commonly contains lamellae of rutile. There is usually little exsolution near flow margins and more extensive exsolution in the massive flow interiors. The degree of secondary oxidation is just the opposite, with more extensive oxidation near flow margins.

Figures 1d, 2d, 3d, 6d, 7d, and $8 d$ show the analyses plotted in part of the $\mathrm{Ti}-\mathrm{Fe}^{2+}-\mathrm{Fe}^{3+}$ system. The analyses have been recalculated into spinel formula $\left(\mathrm{R}_{3} \mathrm{O}_{4}\right)$ and rhombohedral ilmenite formula $\left(\mathrm{R}_{2} \mathrm{O}_{3}\right)$. the data points deviate from the ideal ilmenite-hematite and ülvospine-magnetite joins because of the presence of the other cations, particularly $\mathrm{Mg}$ and $\mathrm{Al}$. Ilmenite has very low $\mathrm{Al}_{2} \mathrm{O}_{3}$ contents $(0.2$ to $0.3 \%)$ and variable $\mathrm{MgO}$ contents (up to $5 \%$ ); the titanomagnetite generally contains more $\mathrm{Al}_{2} \mathrm{O}_{3}(0.5$ to $3.1 \%)$ and moderate $\mathrm{MgO}$ contents (up to 5.4\%). When ilmenite and titanomagnetite coexist, $\mathrm{MgO}$ is partitioned roughly evenly between the two phases. Groundmass titanomagnetite often contains a trace of $\mathrm{Cr}_{2} \mathrm{O}_{3}$. There are no systematic differences between the $\mathrm{Fe}-\mathrm{Ti}$ oxides in the tholeiitic and alkalic basalts.

The equilibration temperatures for ilmenite-magnetite pairs (Table 6, 7 and 11) are based on Lindsley and Rumble's (1977) modification of the original BuddingtonLindsley (1964) geothermometer. All the determinations of $\mathrm{T}$ and $\mathrm{fO}_{2}$ fall on or near the FMQ buffer.

\section{ACKNOWLEDGMENTS}

We thank A. Parkes and W. Holzworth for assistance with the electron microprobe analyses at MIT and SUNY, respectively, and D. Wald for assistance manipulating and plotting the voluminous data used in this paper. This research was supported by the National Science Foundation, Oceanography Section (Submarine Geology and Geophysics) grants OCE-7622193A01 and OCE-78-20058 to A. E. Bence and OCE76-82515 to D. A. Clague.

\section{REFERENCES}

Albee, A. L. and Ray, L., 1970. Correction factors for electron probe analysis of silicates, oxides, carbonates, phosphates, and sulfates, Anal. Chem., 42, pp. 1408-1414.

Beeson, M. H., 1976. Petrology, mineralogy, and geochemistry of the East Molokai Volcanic Series, Hawaii. Geol. Surv. Prof. Paper 961, 53 pp.

Bence, A. E. and Albee, A. L. 1968. Empirical correction factors for the electron microanalysis of silicates and oxides, $J$. Geol., v. 76, pp. 382-403.

Bender, J. F., Hodges, F. N., and Bence, A. E., in press. Petrogenesis of basalts from the project FAMOUS area: Experimental study from $1 \mathrm{~atm}$. to $15 \mathrm{~Kb}$, Earth Planet. Sci. Letters.

Buddington, A F. and Lindsley, D. H., 1964. Iron-titanium oxide minerals and synthetic equivalents, Jour. Petrol, v. 5, pp. 310-357.

Drake, M. J., 1976. Plagioclase-melt equilibria, Geochim. Cosmochim. Acta, v. 40, pp. 457-465.

Evans, B. W. and Frost, B. R., 1975. Chrome-spinel in progressive metamorphism-a preliminary analysis, Geochim. et Cosmochim. Acta, v. 39, pp. 959-972.

Evans, B. W. and Wright, T. L., 1972. Composition of liquidus chromite from the 1759 (Kilauea Iki) and 1965 (Makao-puhi) eruptions of Kilauea Volcano, Hawaii, Am. Mineral., v. 57, pp. 217-230. 

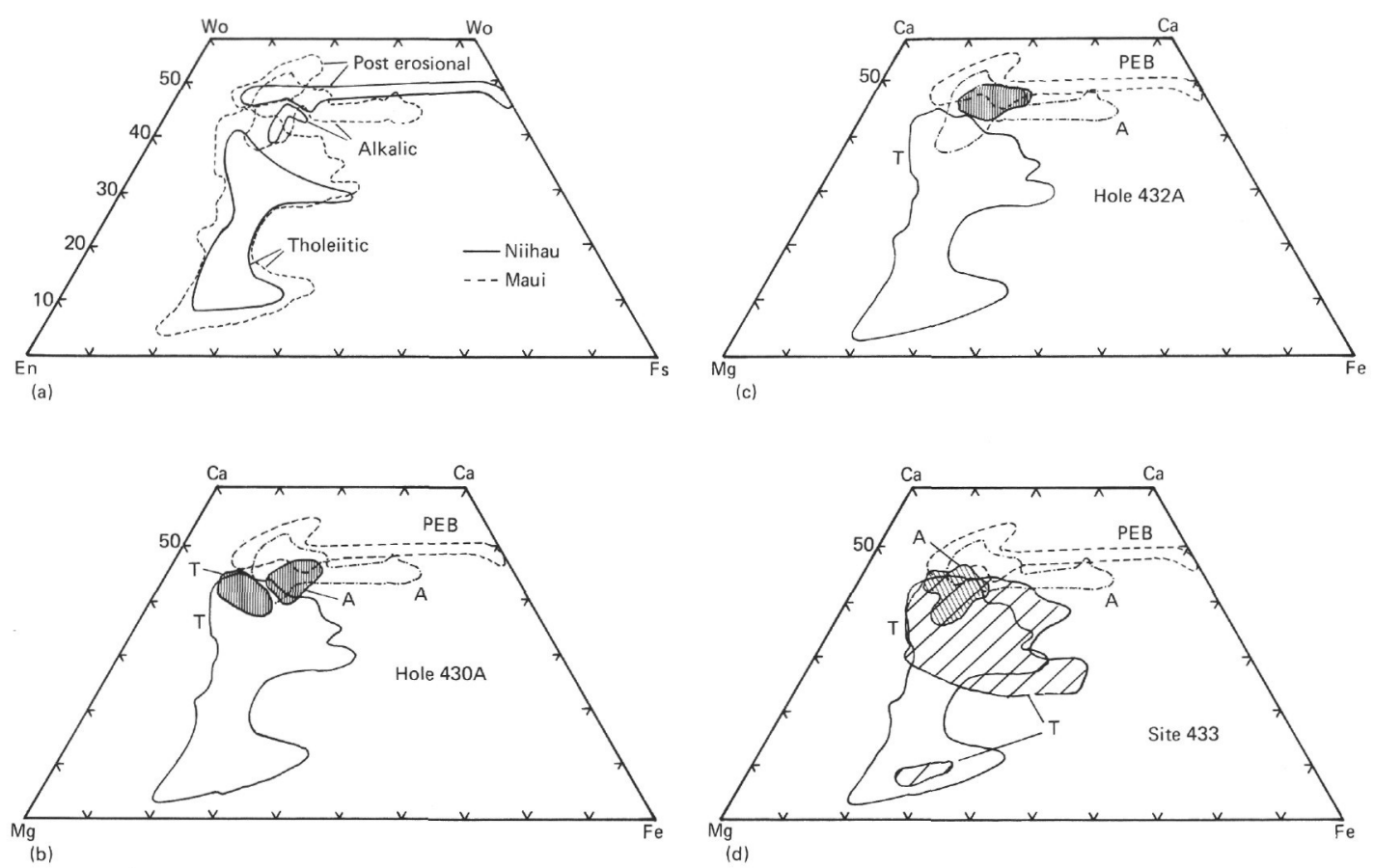

Figure 13. (a) Quadrilateral components of clinopyroxenes in tholeitic (T), alkalic (A), and post-erosional nephelinic basalts (PEB) from Maui (Fodor et al., 1975) and from Niihau (Clague, unpublished data). (b) The fields for the pyroxenes from the hawaiites (A) and tholeiitic (T) basalts from Hole 430A. (c) The field for the pyroxenes from the alkalic basalts from Hole $432 \mathrm{~A}$. (d) The fields for the pyroxenes from the alkalic (A) and tholeiitic (T) basalts from Site 433.

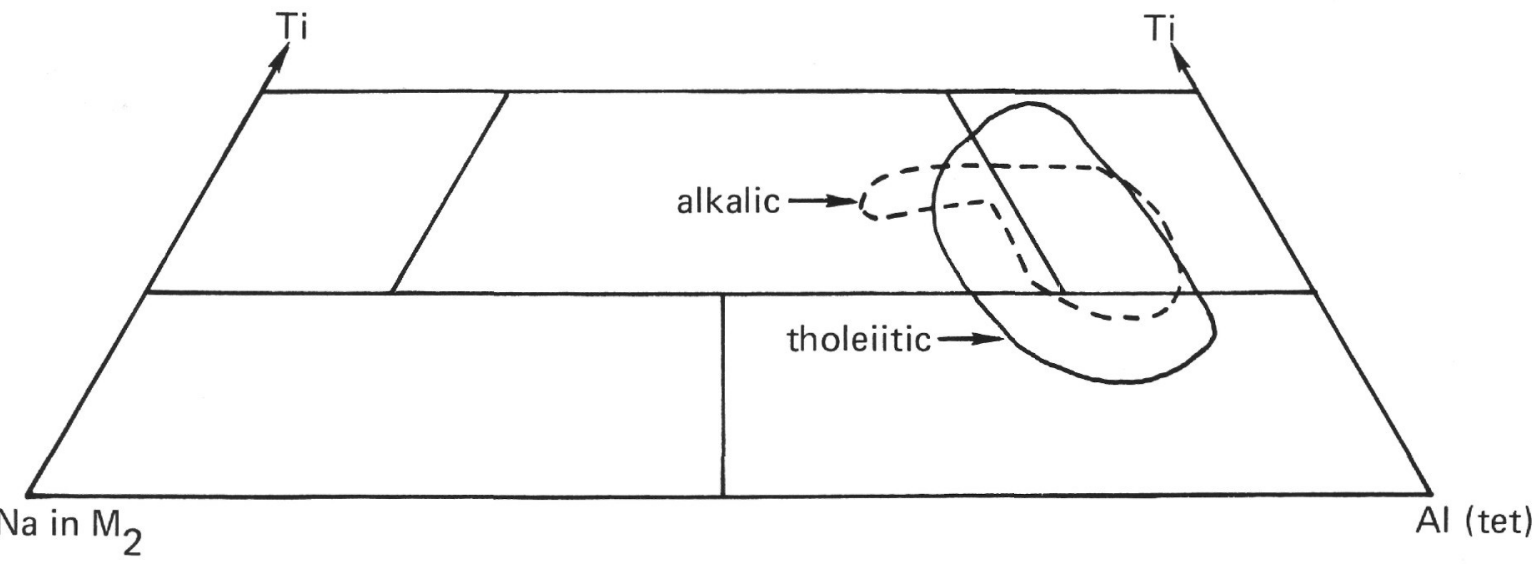

Figure 14. The "other" components of pyroxenes from all sites. The fields for alkalic basalts and hawaites and the tholeiitic basalts are shown.

Fisk, M. R., Schilling, J-G., and Sigurdsson, H., 1978. Olivine geothermometry of Reykjanes Ridge and Iceland tholeiites, Trans. Am. Geophys. Union, v. 59, p. 410.

Fodor, R. V., Keil, K., and Bunch, T. E., 1975. Contributions to the mineral chemistry of Hawaiian rocks IV. Pyroxenes in rocks from Haleakala and West Maui volcanoes, Maui, Hawaii, Contrib. Mineral. Petrol., v. 50, pp. 173-195.

Haggerty, S. E., 1976. Oxide Minerals., Mineralogic Soc. Am. Short Course notes, v. 3, ed. by D. Rumble, III., pp. Hg 101-Hg 277.

Keil, K., Fodor, R. V., and Bunch, T. E., 1972. Contributions to the mineral chemistry of Hawaiian rocks II. Feldspars and interstitial material in rocks from Haleakala and West
Maui Volcanoes, Maui, Hawaii, Contrib. Mineral. Petrol., v. 37, pp. 253-276.

Leung, I. S., 1974. Sector-zoned titanaugite: morphology, crystal chemistry and growth, American Mineralogist, v. 59, pp. $127-138$.

Lindsley, D. H. and Rumble, D., 1977. Magnetite-ilmenite geothermometer-oxybarometer-Evaluation of old and new data, Trans. Am. Geophys. Union, v. 58, p. 519.

Loney, R. A., Himmelberg, G. R., and Coleman, R. G., 1971. Structure and petrology of the Alpine-type peridotite at Burro Mountain, California, USA, Jour. Petrol., v. 12, pp. 245-309. 

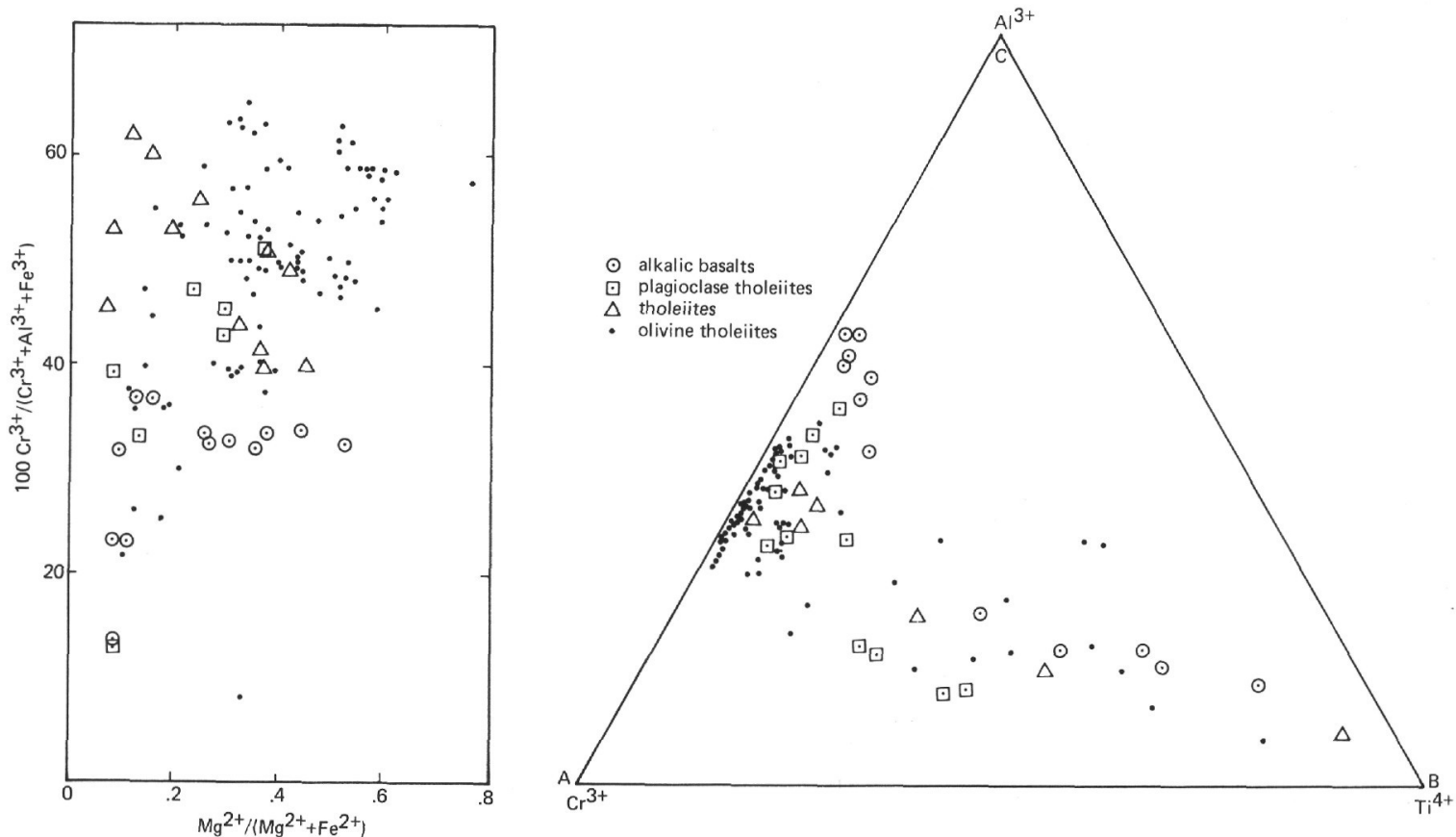

Figure 15. (a) $100 \mathrm{Cr}^{3+} /\left(\mathrm{Cr}^{3+}+\mathrm{Al}^{3+}+\mathrm{Fe} \mathrm{Fe}^{\mathrm{F}}\right)$ versus $\mathrm{Mg}^{2+} /\left(\mathrm{Mg}^{2+}+\mathrm{Fe}^{2+}\right)$ for chrome spinel in alkalic basalts $(\odot)$, olivine tholeiites $(\bullet)$, plagioclase tholeiites $(\odot)$, and tholeites $(\triangle)$. (b) Cr-Ti-Al ternary diagram for the chrome spinels in all samples. Symbols as in (a).

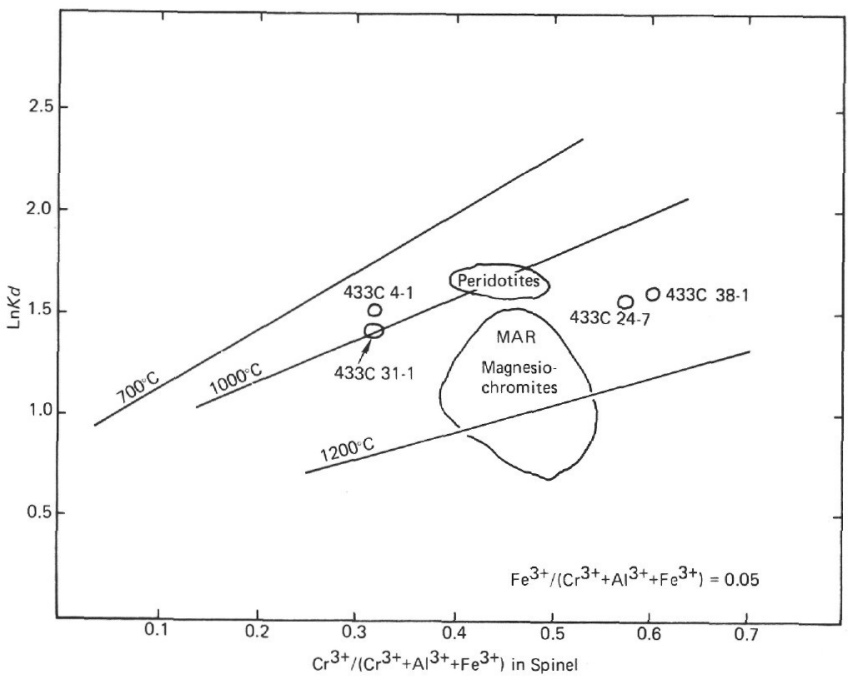

Figure 16. Variation diagram of $\mathrm{Ln} \mathrm{K}_{\mathrm{D}}^{*}$ versus $\mathrm{Cr}^{3+}$ / $\left(\mathrm{Cr}^{3+}+\mathrm{Al}^{3+}+\mathrm{Fe}^{3+}\right)$ for chrome spinel olivine pairs in basalt from Site 433. Ln $\mathrm{K}_{\mathrm{D}}^{*}$ is defined by Evans and Frost (1975). $\mathrm{Fe}^{3+} /\left(\mathrm{Fe}^{3+}+\mathrm{Cr}^{3+}+\right.$ $\mathrm{Al}^{3+}$ ) in the spinel is corrected to 0.05 . The $700^{\circ}$ and $1200^{\circ}$ isotherms are from Evans and Frost (1975). The $1000^{\circ}$ isotherm is from Clague (unpublished data). The fields for alpine peridotite spinel (Loney et al., 1971), and Mid-Atlantic Ridge chromites (Sigurdsson and Schilling, 1976) are shown for comparison.
Miyashiro, A., Shido, F., and Ewing, M., 1970. Crystallization and differentiation in abyssal tholeiites and gabbros from mid-ocean ridges, Earth Planet. Sci. Lett., v. 7, pp. 361-365.

Papike, J. J., Cameron, K. L., and Baldwin, K., 1974. Amphiboles and pyroxenes: Characterization of other than quadrilateral components and estimates of ferric iron from microprobe data, Geol. Soc. Am. Abstr. Programs, 6, pp. 1053-1054.

Peck, D. L., 1978. Cooling and vesiculation of Alae Lava Lake, Hawaii, U.S. Geol. Surv. Prof. Paper 935-B, 59 pp.

Ridley, W. I., 1977. The crystallization trends of spinels in Tertiary basalts from Rhum and Muck and their petrogenetic significance, Contrib. Mineral. Petrol., v. 64, pp. 243255.

Roeder, P. L. and Emslie, R. F. 1970. Olivine-liquid equilibrium, Contrib. Mineral. and Petrol., v. 29, pp. 275-289.

Sigurdsson, H., and Schilling, J-G., 1976. Spinels in MidAtlantic Ridge basalts: Chemistry and occurrence, Earth Planet. Sci. Lett., v. 29, pp. 7-20.

Thompson, R. N. and Tilley, C. E., 1969. Meltin and crystallization relations of Kilauea basalts of Hawaii. The lavas of the 1959-1960 Kilauea eruption, Earth and Planet Sci. Lett., v. 5, pp. 469-477.

Wass, S. Y., 1973. The origin and petrogenetic significance of hour-glass zoning in titaniferous clinopyroxenes, Mineral. Mag., v. 39, pp. 133-144. 